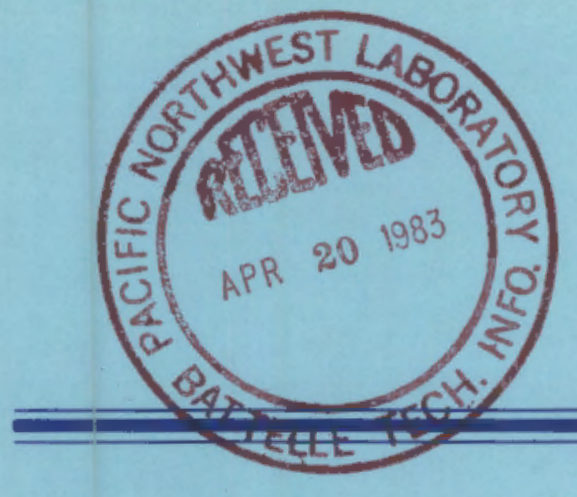

PNL-446I

NUREG/CR-3078

PNL-4461

\title{
Model Evaluation of Seepage from Uranium Tailings Disposal Above and Below the Water Table
}

Prepared by R. W. Nelson, P. R. Meyer, P. L. Oberlander, S. C. Sneider, D. W. Mayer, A. E. Reisenauer

Pacific Northwest Laboratory

Operated by

Battelle Memorial Institute

Prepared for

U.S. Nuclear Regulatory

Commission 


\section{NOTICE}

This report was prepared as an account of work sponsored by an agency of the United States Government. Neither the United States Government nor any agency thereof, or any of their employees, makes any warranty, expressed or implied, or assumes any legal liability of responsibility for any third party's use, or the results of such use, of any information, apparatus, product or process disclosed in this report, or represents that its use by such third party would not infringe privately owned rights.

\section{Availability of Reference Materials Cited in NRC Publications}

Most documents cited in NRC publications will be available from one of the following sources:

1. The NRC Public Document Room, 1717 H Street, N.W. Washington, DC 20555

2. The NRC/GPO Sales Program, U.S. Nuclear Regulatory Commission, Washington, DC 20555

3. The National Technical Information Service, Springfield, VA 22161

Although the listing that follows represents the majority of documents cited in NRC publications, it is not intended to be exhaustive.

Referenced documents available for inspection and copying for a fee from the NRC Public Docu. ment Room include NRC correspondence and irternal NRC memoranda; NRC Office of Inspection and Enforcement bulletins, circulars, information notices, inspection and investigation notices; Licensee Event Reports; vendor reports and correspondence; Commission papers; and applicant and licensee documents and correspondence.

The following documents in the NUREG series are available for purchase from the NRC/GPO Sales Program: formal NRC staff and contractor reports, NRC-sponsored conference proceedings, and NRC booklets and brochures. Also available are Regulatory Guides, NRC regulations in the Code of Federal Regulations, and Nuclear Regulatory Commission Issuances.

Documents available from the National Technical Information Service include NUREG series reports and technical reports prepared by other federal agencies and reports prepared by the Atomic Energy Commission, forerunner agency to the Nuclear Regulatory Commission.

Documents available from public and special technical libraries include all open literature items, such as books, journal and periodical articles, and transactions. Federal Register notices, federal and state legislation, and congressional reports can usually be obtained from these libraries.

Documents such as theses, dissertations, foreign reports and translations, and non-NRC conference proceedings are available for purchase from the organization sponsoring the publication cited.

Single copies of NRC draft reports are available free upon written request to the Division of Technical Information and Document Control, U.S. Nuclear Regulatory Commission, Washington, DC 20555.

Copies of industry codes and standards used in a substantive manner in the NRC regulatory process are maintained at the NRC Library, 7920 Norfolk Avenue, Bethesda, Maryland, and are available there for reference use by the public. Codes and standards are usually copyrighted and may be purchased from the originating organization or, if they are American National Standards, from the American National Standards Institute, 1430 Broadway, New York, NY 10018. 
NUREG/CR-3078

PNL-4461

RU

\section{Model Evaluation of Seepage from Uranium Tailings Disposal Above and Below the Water Table}

Manuscript Completed: January 1983

Date Published: March 1983

Prepared by

R. W. Nelson, P. R. Meyer, P. L. Oberlander,

S. C. Sneider, D. W. Mayer, A. E. Reisenauer

Pacific Northwest Laboratory

Richland, WA 99352

\section{Prepared for}

Division of Health, Siting and Waste Management

Office of Nuclear Regulatory Research

U.S. Nuclear Regulatory Commission

Washington, D.C. 20555

NRC FIN B2370 



\section{ABSTRACT}

Model simulations identify the rate and amount of leachate released to the environment if disposed uranium mill tailings come into contact with ground water or if seepage from tailings reaches ground water. In this study, simulations of disposal above and below the water table, with various methods of leachate control, were compared. Three leachate control methods were used in the comparisons: clay bottom liners; stub-sidewall clay liners; and tailing drains with sumps, with the effluent pumped back from the sumps. The best leachate control for both above and below the water table is a combination of the three methods. The combined methods intercept up to $80 \%$ of the leachate volume in pits above the water table and intercept essentially all of the leachate in pits below the water table. Effluent pumping, however, requires continuous energy costs and an alternative method of disposal for the leachate that cannot be reused as makeup water in the mill process. Without the drains or effluent pumping, the clay bottom liners have little advantage in terms of the total volume of leachate lost. The clay liners do reduce the rate of leachate flow to the ground water, but the flow continues for a longer time. The buffering, sorption, and chemical reactions of the leachate passing directly through the liner are also advantages of the liner. 



\section{ACKNOWLEDGMENTS}

This study was sponsored and supported by the Division of Health, Siting and Waste Management, Office of Nuclear Regulatory Research under FIN B2370, Task 5: Disposal Techniques Allowing Contact with Ground Water. The authors acknowledge the helpful suggestions throughout the project of Don F. Harmon, project administrator for NRC. Special recognition and appreciation is expressed to Lysle $C$. Schwendiman and Dr. Glendon $W$. Gee who served as PNL Project Managers during the last year. The authors also thank Chris $A$. Newbill and Tom $\mathrm{J}$. Mckeon for their contributions to the computer analysis and Brenda $X$. Marshall, technical editor, for her help in preparing this document. 



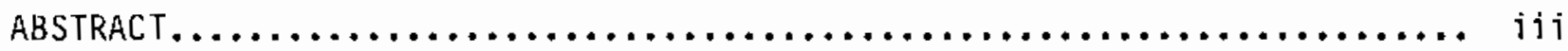

ACKNOWLEDGMENTS.....................................

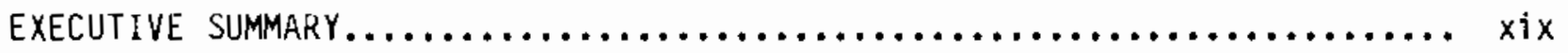

INTRODUCTION........................................ 1

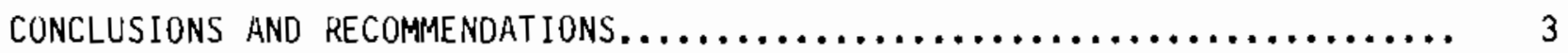

ANALYSIS TECHNIQUES.................................. 5

FLUID FLOW ANALYSIS............................... 5

Model Guide of Tailings Pits........................ 5

Soil Material Properties............................. 10

Results from Fluid Flow Analysis..................... 11

TRANSPORT ANALYSIS............................... 11

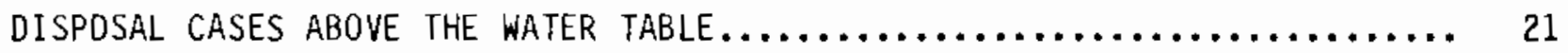

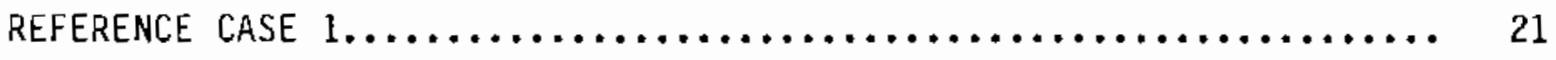

Fluid Flow Analysis.............................. 21

Transport Analysis.............................. 24

CASE $2--W I T H$ CLAY BOTTOM LINER ....................... 28

Fluid Flow Analysis............................ 28

Transport Analysis............................. 28

CASE $3-$. CLAY BOTTOM AND STUB-SIDEWALL LINERS WITH DRAINS.......... 32

Fluid Flow Andysis.............................. 32

Transport Analysis.............................. 36

CASE 4--SIMILAR TO CASE 3, WITH A HORIZONTAL WATER TABLE......... 36

Fluid Flow Алalysis ............................. 38

Transport Analysis............................. 38 
DISPOSAL CASES FOR BELOW THE WATER.......................... 45

CASE $5-$-Below the water table Reference CaSE.................. 45

Fluid Flow Analysis $\ldots \ldots \ldots \ldots \ldots \ldots \ldots \ldots \ldots \ldots \ldots \ldots \ldots, \quad 45$

Fluid Transport Analysis.............................. 45

Tailing Leaching by Ground Water........................ 50

CASE 6 --BelOW THE WATER TABLE WITH BOTTOM Liner............... 56

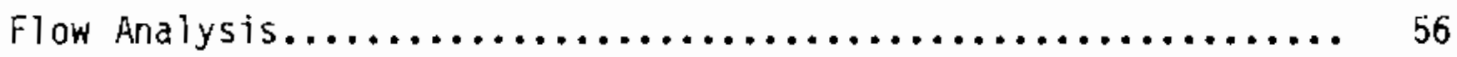

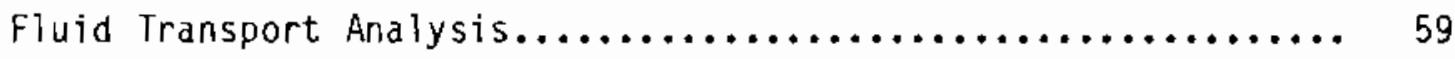

CASE 7--BELOW WATER TABLE WITH DRAINS, CLAY BOTTOM LINER ANO STUBWALL LINERS.............................. 61

Flow Analysis $\ldots \ldots \ldots \ldots \ldots \ldots \ldots \ldots \ldots \ldots \ldots \ldots \ldots \ldots \ldots \ldots, 61$

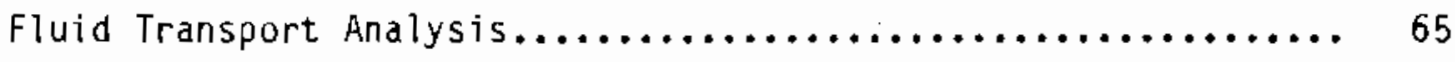

DISCUSSION OF RESOLTS..................................... 67

REFERENCES $. \ldots \ldots \ldots \ldots \ldots \ldots \ldots \ldots \ldots \ldots \ldots \ldots \ldots \ldots \ldots \ldots \ldots \ldots \ldots \ldots \ldots \ldots, 71$

APPENDIX A--NOTATION.......................................... A

APPENDIX B--POTENTIAL ANU MOISTURE CONTENT PLOTS: REFERENCE CASE $1 \ldots \ldots$ B. 1 APPENDIX C.--POTENTIAL AND MOISTURE CONTENT PLOTS: CASE 2 WITH CLAY BOTTOM LINER.................................... C.1

APPENDIX D--POTENTIAL AND MOISTURE CONTENT PLOTS: CASE 3 WITH CLAY BUTTOM AND STUB-SIDEWALL LINERS WITH DRAINS $. \ldots \ldots \ldots \ldots \ldots \ldots, 0.1$

APPENDIX E--POTENTIAL AND MOISTURE CONTENT PLOTS: CASE 4 WITH

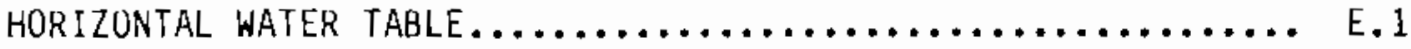

APPENDIX F--POTENTIAL AND MOISTURE CONTENT PLOTS: CASE 5--BELOW THE WATER TABLE REFERENCE CASE............................ F.1

APPENDIX G--POTENTIAL AND MOISTURE CONTENT PLOTS: CASE 6--WITH CLAY BOTTOM LINER................................... G.1

APPENDIX H--POTENTIAL AND MOISTURE CONTENT PLOTS: CASE 7--WITH CLAY BOTTOM AND STUB-SIDEWALL LINERS WITH DRAINS ............... H.1 
FIGURES

la Cross-Section of a Tailings Disposal Pit Above the Water

Table -- Uncovered....................................

1b Cross-Section of a Tajlings Disposal Pit Above the Water

Table -- Covered.................................... 6

2 Right, or Upgradient, Half of TRUST Grid Number One............ 8

3 Right, or Upgradient, Half of TRUST Grid Number Two............. 9

4a Tailings Characteristic Saturation Curve................... 12

$4 b \quad$ Tailings Intrinsic Permeability Curve....................... 12

5a Sandstone No.1 Characteristic Saturation Curve............... 13

5b Sandstone No. I Intrinsic Permeability Curve................. 13

6a Sandstone No. 2 Characteristic Saturation Curve................ 14

6 b Sandstone No. 2 Intrinsic Permeability Curve.................. 14

7a Clay Characteristic Saturation Curve..................... 15

7 b Clay Intrinsic Permeability Curve........................ 15

8a Overburden Soil Characteristic Saturation Curve............... 16

8 bverburden Soil Intrinsic Permeability Curve................. 16

9a Drain Filter Material Characteristic Saturation Curve............ 17

gb Drain Filter Material Intrinsic Permeability Curve............. 17

10a Initial Hydraulic Potential Contours--Above The Water Table,

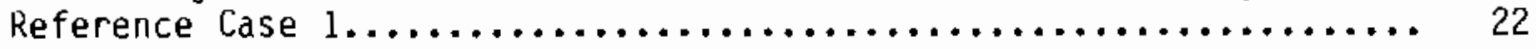

10b Final Hydrautic Potential Contours Above The Water Table,

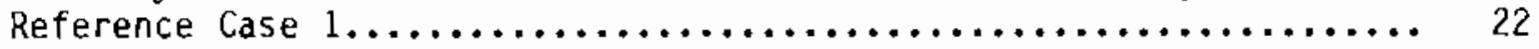

lla Initial Moisture Content Contours--Above The Water Tabie,

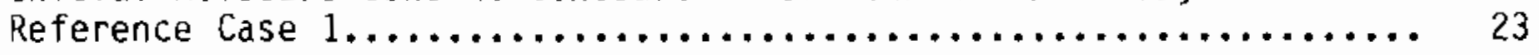

11b Final Moisture Content Contours--Above The Water Table,

Reference Case $1 . \ldots \ldots \ldots \ldots \ldots \ldots \ldots \ldots \ldots \ldots \ldots \ldots \ldots \ldots \ldots \ldots \ldots \ldots . \ldots \ldots$

12a Hydraulic Potential Contours at 1523 Days as Major Tailings Fluid Outflow Occurs at Lower End of the Pit..................... 25 
12b Hydraulic Potential Contours at 1544 Days as Tailings Fluid Outflow Expands Upgradient Along Pit........................ 25

12c Hydraulic Potential Contours at 1577 Days at Maximum Tailings Fluid Outflow from the Pit................................... 26

13a Transport Pathines--Above The Water Table, Reference Case 1....... 27

13b Additional Pathlines--Above the Water Table, Reference Case 1...... 27

14a Initial Hydraulic Potential Contours--Above The Water Table,

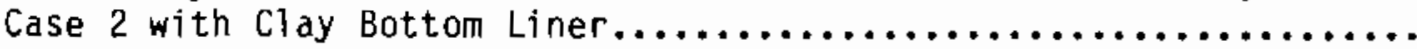

14b Final Hydraulic Potential Contours--Above The Water Table, Case 2 with Clay Bottom Liner................................

15a Initial Motsture Content Contours--Above The Water Table, Case 2 with Bottom Liner...................................

15b Final Moisture Cantent Contours--Above The Water Table, Case 2 with Bottom Liner......................................... 30

16a Transport Pathlines for Case 2 with Clay Bottom Liner............. 31

16b Additional Transport Pathlines for Case 2 with Clay Bottom Liner.... 31

17 Detailed Dimensions in Meters (feet) of Case 3--with Clay Bottom Liner, Stub-Sidewall Liners, and Drains.................. 33

18a Initial Hydraulic Potential Contours--Above the Water Table, Case 3, with Bottom Liner, Stub-Sidewall Liners, and Drains........ 34

18b Final Hydraulic Potential Contours--Above the Water Table, Case 3, with Bottom Liner, Stub-Sidewall Liners, and Drains................

19a Initial Moisture Content Contours--Above the Water Table, Case 3, with Bottom Liner, Stub-Sidewall Liners, and Drains.............. 35

19b Final Moisture Content Contours--Above the Water Table, Case 3, with Bottom Liner, Stub-Sidewall Liners, and Drains.............. 35

20 Leachate Pathlines--Above the Water Table, Case 3, with Bottom Liner, Stub-Sidewall Liners, and Drains.......................

21a Initial Hydraulic Potential Contours--Above the Water Table, Case 4 , with a Static Water Tabie.............................

21b Final Hydraulic Potential Contours--Above the Water Table, Case 4 with a Static Water Table.................................... 
22a Initial Moisture Content Contours--Above the Water Table,

Case 4 , with a Static Water Table........................ 41

22b Final Moisture Content Contours-Above the Water Table, Case 4

with a Static Water Table................................ 42

23 Transport Pathiline--Above the Water Table, Case 4 with a

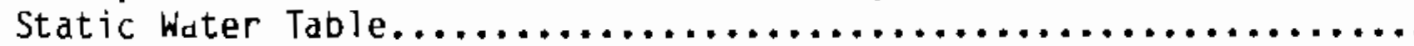

24a Initial Hydraulic Potential Contours--Below the Water Tabie,

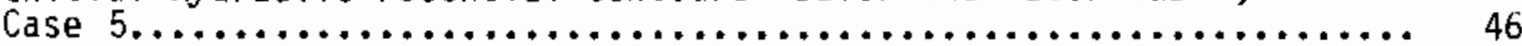

24b Finai Hydraulic Potential Contours-- Below the Water Table

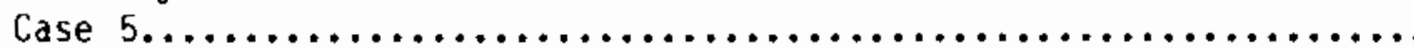

25a Initial Moisture Content Contours--Below the Water Tabie,

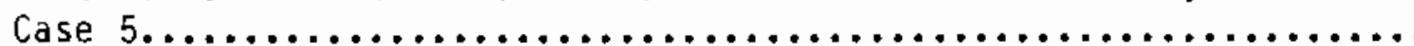

25b Final Moisture Content Contours-Below the Water Table,

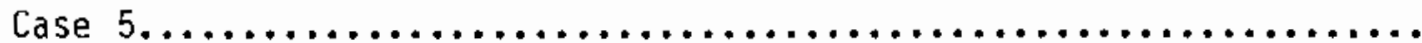

26 Pathlines of Particles Starting at Edge of Pit at Time $(\mathrm{t}=0)$

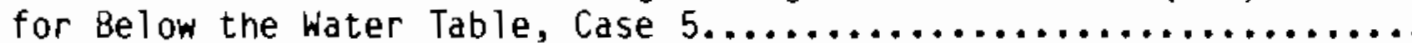

27 Effluent Sulfate Concentration from Laboratory Tailings Columns

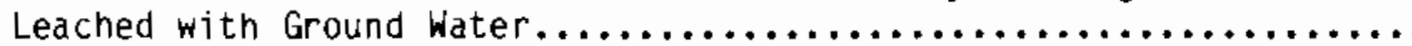

28 Location/Arrival Time Results for Pathlines at Downstream

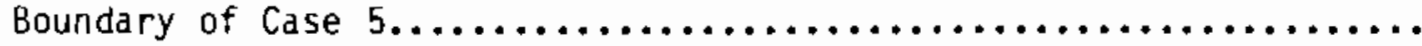

29 Unit Outflow Rate of Fiuid as a Function of Location Along the

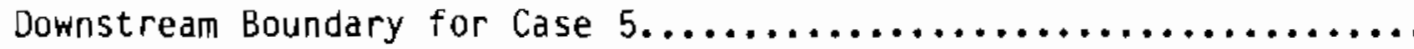

30 Sulfate Flow Rate in Ground water Away from the Below-the-

Water-Table Tailings Disposal Pit in Case $5 . . . . . . . . . . . . . .$.

3la Initial Hydraulic Potential Contours--Below the Water Table,

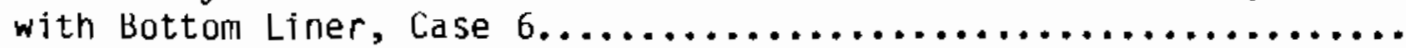

31b Final Hydraulic Potential Contours--Below the Water Table,

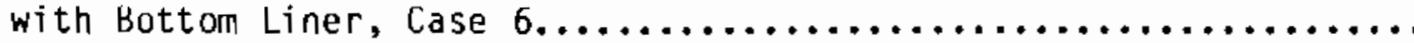

32a Initial Moisture Content Contours--Below the Water Table, with Bottom Liner, Case $6 \ldots \ldots \ldots \ldots \ldots \ldots \ldots \ldots \ldots \ldots \ldots \ldots \ldots \ldots . \ldots \ldots$

3:b Final Moisture Content Contours--Below the Water Table,

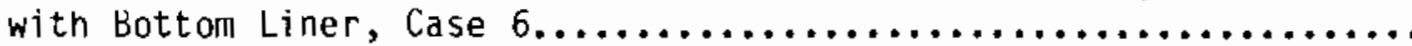

33 Time History of Drainable Fluid Content in Tailings-Below Water Table, Bottom Liner Case 6. 
34 Pathlines of Tailings Leachate--Below the Water Table,

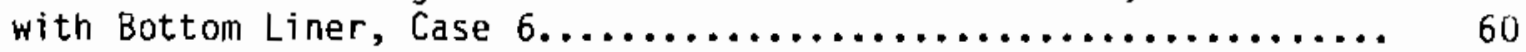

35a Initial Hydraulic Potential Contours--Below the Water Table, Case 7 with Bottom Liner, Stub-Sidewalls, and Drains

with Pumping.........................................

35b Final Hydraulic Potential Contours--Below the Water Table, Case 7 with Bottom Liner, Stub-Sidewalls, and Drains with Pumping........

36a Initial Moisture Content Contours--Below the Water Table, Case 7 with Bottom Liner, Stub-Sidewalis, and Lrains with Pumping........

36b Final Moisture Content Contours--Below the Water Table, Case 7 with Bottom Liner, Stub-Sidewalls, and Drains with Pumping........

37a Schematic Diagram of Initial Water Movement Near the Upstream

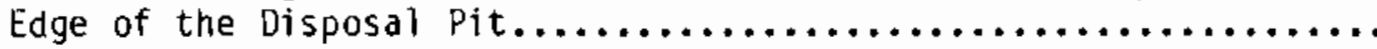

37b Schematic Diagram of Water Movement a Short Time Later Near

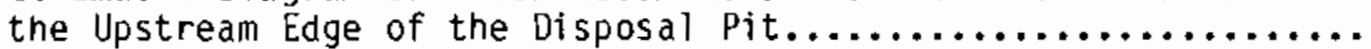

38 Fluid Pathlines for Below the Water Table, Case 7 with Pumped Drains, Clay Bottom Liner, and Stub-Sidewall Liners..............

B.1a Hydraulic Potential Contours at 1575 Days (4.3 years)--Above the water Table, Reference Case 1.........................

B.1b Moisture Content Contours at 1575 Days (4.3 years)--Above

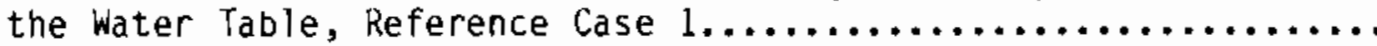

B.2a Hydraulic Potential Contours at 2500 Days (6.8 years)--Above the water Table, Reference Case $1 . . \ldots \ldots \ldots \ldots \ldots \ldots \ldots \ldots \ldots \ldots$

B. 2b Moisture Content Contours at 2500 Days ( 6.8 years)--Above the Water Table, Reference Case 1..........................

B. 3a Hydraulic Potential Contours at 3437 Days (9.4 years)--Above

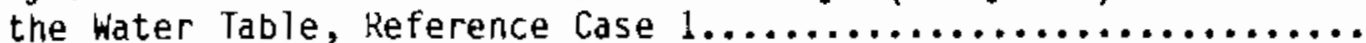

B.3b Moisture Content Contours at 3437 Days (9.4 years)--Above the

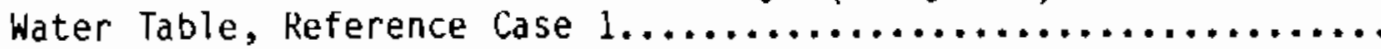

B. 4a Hydraulic Potential Contours at 6088 Days (16.7 years)--Above the Water Table, Reference Case 1..........................

B.4b Moisture Content Contours at 6088 Days (16.7 years)--Above the water Table, Keference Case 1.........................

B.5a Hydraulic Potential Contours at 42,522 Days ( 116.5 years)--

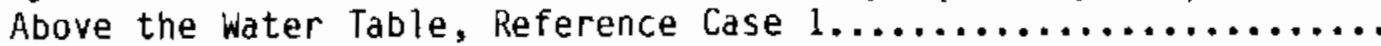


B.5b Moisture Content Contours at 42,522 Days (116.5 years)--

Above the Water Table, Reference Case 1.................... B. 5

C.la Hydraulic Potential Contours at 4852 Days (13.3 years)--

Above the Water Table, Case 2 with Clay Bottom Liner............ C.1

C. 1b Mojsture Content Contours at 4852 Jays (13.3 years)--Above

the Water Table, Case 2 with Clay Bottom Liner................. C.1

C.2a Hydraulic Potential Contours at 9731 Days (26.7 years)--

Above the Water Table, Case 2 with Clay Bottom Liner............. C.2

C.2b Moisture Content Contours at 9731 Days (26.7 years)--Above

the Water Table, Case 2 with Clay Bottom Liner................ c.2

C.3a Hydraulic Potential Contours at 15,479 Days (42.4 years)--

Above the Water Table, Case 2 with Clay Bottom Liner............ C.3

C.3b Moisture Content Contours at 15,479 Days (42.4 years)--Above

the Water Table, Case 2 with Clay Bottom Liner................ c.3

C.4a Hydraulic Potential Contours at 27,753 Days (76.0 years)--

Above the Water Table, Case 2 with Clay Bottom Liner............ C.4

C.4b Moisture Content Contours at 27,753 Days (76.0 years)--Above

the Water Table, Case 2 with Clay Bottom Liner................. C.4

C.5a Hydraulic Potential Contours at 46,896 Days (128.5 years)--

Above the Water Table, Case 2 with Clay Bottom Liner............ C.5

C.5b Mojsture Content Contours at 46,896 Days (128.5 years)--Above

the Water Table, Case 2 with $\mathrm{Cl}$ ay Bottom Liner............... c.5

D. la Hydraulic Potential Contours at 33.6 Days--Above the water

Table, Case 3 with Clay Bottom and Stub-Sidewall Liners

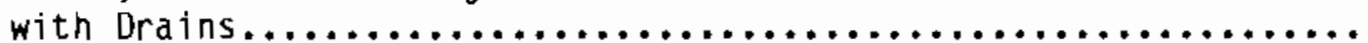

U. 1

D. Ib Moisture Content Contours at 33.6 Days--Above the Water

Table, Case 3 with Clay Bottom and Stub-Sidewall Liners

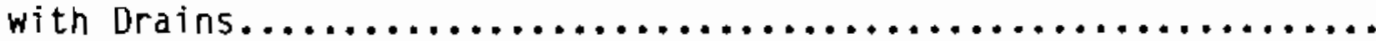

D.2a Hydraulic Potential Contours at 247 Days--Above the water

Table, Case 3 with Clay Bottom and Stub-Sidewall Liners

with Drains.........................................

D. 2

D. 2b Moisture Content Contours at 247 Days--Above the Water Table, Case 3 with Clay Bottorn and Stub-Sidewall Liners with Urains...... 
0.3a Hydraulic Potential Contours at 513 Days ( 1.4 years)--Above the Water Table, Case 3 with Clay Bottom and Stub-Sidewall Liners with Drains....................................

D. 3b Moisture Content Contours at 513 Days ( 1.4 years)--Above the Water Table, Case 3 with Clay Bottom and Stub-Sidewall

Liners with Drains.

0.4a Hydraulic Potential Contours at 1498 Days (4.1 years)--Above the Water Table, Case 3 with $\mathrm{Cl}$ ay Bottom and Stub-Sidewall

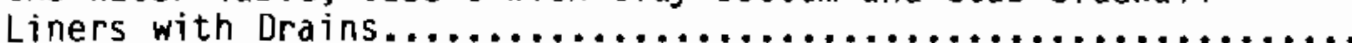

D. 4b Moisture Content Contours at 1498 Days (4.1 years)--Above the Water Table, Case 3 with Clay Bottom and Stub-Sidewall Liners

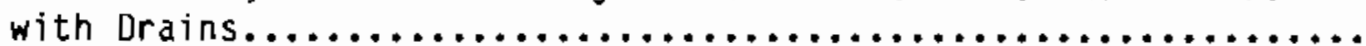

D.5a Hydraulic Potential Contours at 6765 Days (18.5 years)--Above the Water Table, Case 3 with Clay Bottom and Stub-Sidewall Liners with Drains.

D. 5b Moisture Content Contours at 6765 Days (18.5 years)-Above the Water Table, Case 3 with Clay Bottom and Stub-Sidewall Liners

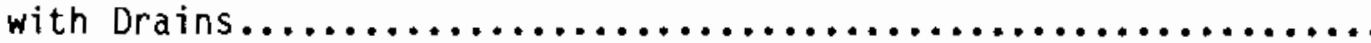

D.6a Hydraulic Potential Contours at 21,495 Days (58.9 years)--Above the Water Table, Case 3 with Clay Bottom and Stub-Sidewall

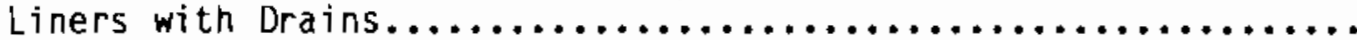

D.6b Moisture Content Contours at 21,495 Days (58.9 years)--Above the Water Table, Case 3 with Clay Bottom and Stub-Sidewall

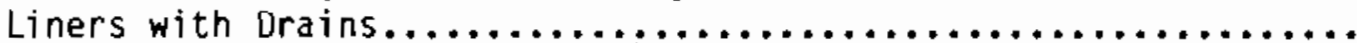

E.la Hydraulic Potential Contours at 34.9 Days--Above the water Table, Case 4 with Horizontal Water Table..................... E. 1

E.1b Moisture Content Contours at 34.9 Days--Above the Water Table, Case 4 with Horizontal Water Table......................

E. 2a Hydraulic Potential Contours at 242.2 Days--Above the water Table, Case 4 with Horizontal Water Table................... E...

E.2b Moisture Content Contours at 242.2 Days--Above the Water Table, Case 4 with Horizontal the Water Table................. E.4

E. 3a Hydraulic Potential Contours at 510 Days (1.4 years)--Above the Water Table, Case 4 with Horizontal Water Table............. E.5

E.3b Moisture Content Contours at 510 bays (1.4 years)--Above the Water Table, Case 4 with Horizontal Water Table. 
E.4a Hydraulic Potential Contours at 1507 Days (4.1 years)--Above the Water Table, Case 4 with Horizontal Water Table..............

E.4b Moisture Content Contours at 1507 Days (4.1 years)--Above the Water Table, Case 4 with Horizontal Water Table............. E.8

E.5a Hydraulic Potential Contours at 6696 Days (18.3 years)--Above the Water Table, Case 4 with Horizontal Water Table..

¿.5b Moisture Content Contours at 6696 Days ( 18.3 years)--Above the Water Table, Case 4 with Horizontal Water Table.

F.la Hydraulic Potential Contours at 276 Days--Below the Water Table Reference Case 5 .

F.1b Mojsture Content Contours at 276 Days-melow the Water Table Reference Case 5 .

F.2a Hydraulic Potential Contours at 974 Days (2.7 years)--Below the Water Table Reference Case 5.

F.2b Moisture Content Contours at 974 Days (2.7 years)--Below the

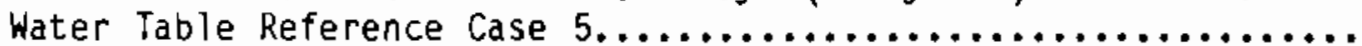

F.3a Hydraulic Potential Contours at 2092 Days ( 5.7 years)--Below

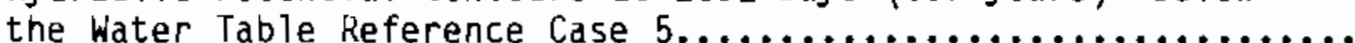

F.3b Moisture Content Contours at 2092 Days (5.7 years)--Below the

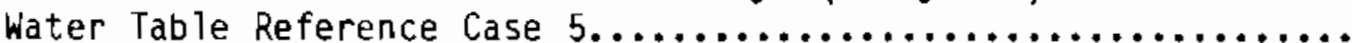

F.4a Hydraulic Potential Contours at 4488 Days (12.3 years)--Below the Water Table Reference Case 5 .

F.4b Moisture Content Contours at 4488 Days (12.3 years)--Below the

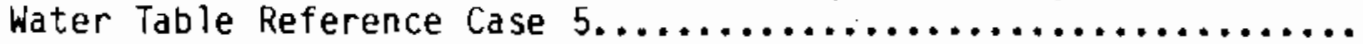

F.5a Hydraulic Potential Contours at 6486 Days (17.8 years)--Beiow the Water Table Reference Case $5 . . . \ldots \ldots \ldots \ldots \ldots \ldots \ldots \ldots \ldots \ldots$

F.5b Moisture Content Contours at 6486 Days (17.8 years)--Below the

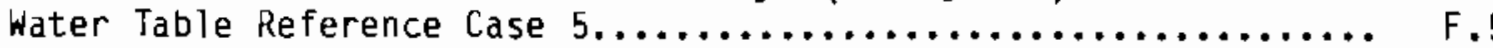

G.la Hydraulic Potential Contours at 713 Days (1.95 years)--Case 6

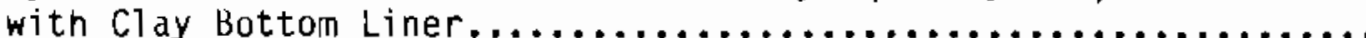

G.1b Moisture Content Contours at 713 Days (1.95 years)--Case 6

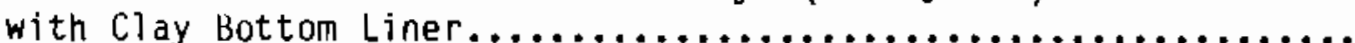

G. 2a Hydraulic Potential Contours at 1384 Days (3.8 years)--Case 6 with Clay Bottom Liner. 
G.2b Moisture Content Contours at 1384 Days (3.8 years)--Case 6

with Clay Bottom Liner............................. G.2

G.3a Hydraulic Potential Contours at 2548 Days (7 years)--Case 6

with Clay Bottom Liner.............................. G. 3

G.3b Moisture Content Contours at 2548 Days (7 years)--Case 6

with $\mathrm{Clay}$ Bottom Liner................................. G.3

G.4a Hydraulic Potential Contours at 4948 Days (13.6 years)--Case 6

with Clay Bottom Liner................................ G.4

G.4b Moisture Content Contours at 4948 Days (13.6 years)--Case 6

with Clay Bottom Liner................................. G.4

G.5a Hydraulic Potential Contours at 7913 Days (21.7 years)--Case 6

with Clay Bottom Liner.............................. G.5

G.5b Moisture Content Contours at 7913 Days (21.7 years)--Case 6

with Clay Bottom Liner.............................. 6.5

H.1a Hydraulic Potential Contours at 32.7 Days--Case 7 with Clay

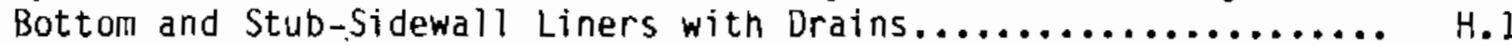

H. 1b Moisture Content Contours at 32.7 Days--Case 7 with Clay

Botton and Stub-Sidewall Liners with Drains.................. H.1

H.2a Hydraulic Potential Contours at 270 Days--Case 7 with Clay

Botton and Stub-Sidewall Liners with Drains.................... H.2

H. 2b Moisture Content Contours at 270 Days--Case 7 with Clay

Bottom and Stub-Sidewall Liners with Drains.................. H.2

H.3a Hydraulic Potential Contours at 747 Days (2 years)--Case 7

with Clay Bottom and Stub-Sidewall Liners with Drains............ H.3

H. 3b Moisture Content Contours at 747 Days (2 years)--Case 7 with Clay Bottom and Stub-Sidewall Liners with Drains................ H.3

H.4a Hydraulic Potential Contours at 2062 Days (5.6 years)--Case 7

with Clay Bottom and Stub-Sidewall Liners with Drains............ H.4

H.4b Moisture Content Contours at 2062 Days (5.6 years)--Case 7

with Clay Bottom and Stud-Sidewall Liners with Drains............ H.4 


\section{TABLES}

1 Selected Physical Characteristics for Soil Material Used in Model Cases........................................... 11

2 Pathline Arriva] Data at Outflow Boundary for Case $5 \ldots \ldots \ldots \ldots . . .49$

3 Summary and Comparison Results from Seven Tajlings Pit Disposal Pits....................................... 68 

Probiems associated with the disposal of uranium mill tailings in belowgrade pits located above and below the water table were studied by Pacific Northwest Laboratory (PNL) through model simulations of ground-water flow and transport. In this study, sponsored by the U.S. Nuclear Regulatory Comrnission (NRC), we simulated and analyzed cases of tailings disposal in below-grade pits above the water table and compared these results with similar simulated cases for disposal below the water table. Thus, we were able to build on the already-accumulated experience for pit disposal above the water table to allow greater understanding of disposal below the water table, that is, greater understanding of leachate losses to the environment and of the benefits of various leachate control methods.

Three cases of pit disposal above a lateral water-table gradient were considered. (A fourth case, in which the disposal pit was located above a horizontal or static water table, was considered as an index to previous studies in this area.) A different leachate control method was used for each of the first three cases. In the first, or reference case, saturated sluiced tailings were in an unlined pit above the water table. The second case involved the same pit, with a clay bottom liner added. The third case provided still more leachate control through stub-sidewall clay liners and drains in the tailings above the bottom clay liner, with the drainage effluent pumped from the pit.

The volume of tailings leachate entering ground water from the pits above the water table was $100 \%, 97.2 \%$, and $20.9 \%$, respectively, for the reference unlined pit, for the pit with the clay-lined bottom, and for the pit with the clay-lined bottom and stub-sidewalls, with pumped drainage effluent. The 75 to $30 \%$ decrease in leachate that enters the ground water as a result of the flumping from the drain sumps in the third case is significant.

The corresponding leachate losses to ground water for the below-the-watertable cases were $142.7 \%, 135.6 \%$, and essentially $0 \%$, based on the $100 \% 1$ oss for the above-the-water-table reference case. Some of the tailings pore solution in this reference case is retained by capillary forces. The greater leachate losses to ground water for the first two cases below the water table (142.7\% and $135.6 \%$ compared to $100 \%$ and $97.2 \%$, respectively) are a result of the ground water flowing through the tailings. The ground water effectively sweeps all the initial pore solution frorn the tailings. These leachate losses, we must remember, represent the leachate volume that is physically swept from the tailings by the ground water flowing through, and do not include the longerterm leaching associated with chemical interactions between ground water and tailings. Without experimental analyses of these chemical interactions, we must assume worst-case situations to assess the overall consequences of leachate loss to the environment. Growing evidence suggests that the detrimental consequences found are often a direct result of these worst-case assumptions. 
On the other hand, essentially no leachate was lost to ground water when the leachate control methods were combined in the below-grade disposal pit. This combination, however, requires that as the ground water enters the tailings and reaches the drains, extra water be pumped from drains. In fact, a $289.7 \%$ volume of fluid (about 2.9 times that of the reference case) must be pumped from the pit drains to assure that leachate will not be lost to ground water. In all of the pumping situations the cost of pumping over time periods of from 1 to 10 years is a factor. (a) Also, if the pumped fluid is not used as process makeup solution, it must be disposed of in an environmentally safe manner.

This study supports earlier work concerning the effectiveness of pumping from drains in pits above the water table to reduce leachate seepage from tailings into ground water. We also found that control by pumping from tailings drains in disposal pits below the water table is even more effective (no leachate loss to ground water, compared to $20.9 \%$ loss from pits above the water table) because greater head drawdown is possible under saturated flow conditions.

(a) See Table 3 for more spedific pumping-time results. 
$\underline{\text { INTRODUCTION }}$

Depositing uranium mill tailings in the pits excavated during surface mining operations lessens the undesirable environmental effects of the tailings (NRC 1980). When open mine pits are not available, tailings can be buried in specially constructed pits (Scarano 1980). The advantages of better radon control and of returning the mine site to nearly the original topography and vegetative habitat may warrant such burial (as opposed to storing tailings in pords above the ground).

On the other hand, buried tailings could contaminate the environment. In particular, drainage from slurried taitings and seepage through the tailings disposal site may contaminate ground water. Appropriate construction practices and control methods, however, should reduce the possibilities for ground-water contamination and, in some cases, essentially eliminate detrimental effects (Neison, Reisenauer and Gee 1980).

To identify effective and economical control methods, we must be able to assess and analyze their potential effects (beneficial and harmful). The needed analysis involves two technical areas. First, the amounts, rates, and flow paths of the water are analyzed because water transports the leachate solute through and away from the tailings pit. Second, the chemical interactions of the solute with the tailings, liner materials, and soil materials are identified to estimate the ultimate quality of the ground water. These evaluations are important because only those parts of the subsurface systen where the solute is conveyed by the ground water can be affected. On the other hand, an evaluation of potential subsurface contamination resulting from the disposal of tailings below the water table is unrealistic if chemical buffering capacities, precipitation, and exchange reactions along the transport pathway are ignored.

In this study we used model simulations to focus on the fluid flow and water transport features of tailings disposal in pits above and below the water table. Our emphasis is on evaluating the effectiveness of various methods to control fluid flow, as applied above and below the water table. The control methods analyzed include clay bottom liners; clay stub-sidewall liners; and drains installed above the clay liners, with pumping of the drainage effluent from the pits.

We defined reference cases (typical disposal situations) for above the water table and then compared the simulations of various modifications for below the water table to these reference cases. These generic reference cases are based on a typical pit cross-section and the soil material charcteristics are based on data representative of the proposed Morton Ranch Uranium Mill Site in Converse County, Wyoming. [See Nelson, Reisenauer and Gee (1980) for a site clescription.] The stratigraphy and material heterogeneity of the cases selected were uncomplicated, to help us determine relative overall performance for tailings disposal above and below the water table. The values from this study should be used for overall comparisons between various disposal alternatives, not for detailed interpretations of any stratigraphic or heterogeneous system. 
Seven cases are discussed in this report:

- Disposar Pits Above the Water Table

Case 1--(reference case), saturated tailings are contained in an unlined pit with no drains, above a sloping water table.

Case 2--sinilar to Case 1, but with a clay liner in the bottom of the pit.

Case 3--similar to Case 2, Dut with clay stub-sidewall liners and drains with sumps added, so the drainage effluent is pumped from sumps.

Case 4--similar to Case 3, but with a static or level (rather than a sloping) regional gradient through the vertical crosssection.

- Disposal Pits Below the Water Table

Case 5--the same as Case 1, Dut with the water table raised $27.4 \mathrm{~m}$

$(90 \mathrm{ft}$ ). (A more detailed tailings leaching analysis is provided for this case.)

Case 6--the same as Case 2, Dut with the water table raised $27.4 \mathrm{~m}$ $(90 \mathrm{ft})$.

Case 7 --the same as Case 3 , but with the water table raised $21.3 \mathrm{~m}$ $(70 \mathrm{ft})$.

This report begins with a discussion of techniques we used to simulate and analyze the seven cases that are presented in this study. Next, the four disposal situations above the water table are described and discussed. These analyses are followed by a discussion of the three disposal cases below the water table. Finally, we compare and contrast the overall results of the fluid control methods simulated. 
The best control of leachate from uranium mill tailings in disposal pits is provided by a combination of a clay bottom liner, clay stub-sidewall liners, and tailings drains with pumping of the effluent. As much as $80 \%$ of the total leachate volume that otherwise would enter ground water from disposal pits above the water table is intercepted by this combination of control features. Model simulations of pits below the water table with the same control combination showed essentially complete control of leachate losses. Pumping of the effluent, however, involves continuing energy costs and requires an alternative method of disposal of any leachate that cannot be reused as mill process makeup water.

When no drains or effluent pumping are involved, the clay bottom liners are less useful. They do reduce the leachate outflow rates, but the leachate continues to flow out over a much longer period of time, resulting in essentially the same total outflow volume of leachate. This pattern is about the same for disposal both above and below the water table, even though more leachate enters the ground water from disposal pits below the water table.

Aithough our analysis of the fluid flow and leachate seepage control is realistic and has provided meaningful results, two related areas of serious technical deficiency remain in our assessment of the fate of tailings Teachate. The first concerns the limited laboratory experimental column studies to determine the change in leachate composition as ground water seeps through tailings. Closely related is the need for experimental column studies an tailings leachate that percolates through coarser natural soils. The reutralization, chemical interactions, and sorption effects on the column effluent concentrations, and also the precipitation-mineralization effects in the column should be known.

Second, we need an appropriate capability to analyze transport, which includes the analysis of sorption, chemical speciation, precipitation, and dissolution reactions for tailings leachate percolating through natural materials. Without such experimental results, coupled with the capability to analyze combined hydrologic transport and chemical interactions, we either cannot do the appropriate analyses or we must assume worst-case situations to assess the overall consequences. From this project and from related NRC research underway at $\mathrm{PNL}$, evidence suggests that the detrimental consequences found are often a direct result of the worst-case assumptions that have been made. Specifically, if transport with chemical speciation, precipitation, and dissolution effects could be realistically analyzed, many of the currently predicted detrimental consequences would probably disappear. 



\section{ANALYSIS TECHNIQUES}

Our analyses for this study are divided into two main categories. The evaluation begins with an analysis of fluid flow in the tailings pit and in the surrounding material. From the flow analysis we obtain vector fields in time and space for the pore velocity of the fluid. These vector fields are used in the second category, the fluid transport analysis, to determine the transport of the water and contaminants throughout the system. From the transport analyses and from the available experimental information on pertinent chemical interactions with the soil materials, we can determine the overall effects of the various leachate controls for disposal pits above and below the water table.

\section{FLUID FLOW ANALYSIS}

To analyze the flow of a generic tailings disposal pit, we numerically simulate fluid flow in both the saturated and partially saturated regimes. In this study, simulations were done in two dimensions, the modeled region being a vertical cross-section (one unit thick) of the pit and surrounding material. Figures la and $1 b$ are schematic diagrams of a typical tailings disposal pit above the water table. Figure la shows the pit before the cover is applied and Figure $1 b$ indicates the structure of the engineered cover system. The simulations for pits below the water table are the same, except the water table has been raised so that the ground water flows through the tailings. All of the pit dimensions are reported in metric units, followed by English units in parentheses.

Model Grid of Tailings Pits

To solve the flow problems we separated pit cross-sections and surrounding areas into discrete irregular elements for use in the TRUST code (Reisenauer et al. 1982). TRUST uses an integrated finite-difference method to solve the conservation of mass equation for the discrete element or cells that together make up the region to be simulated. Each element has a node point at or near the center of mass of the cell. The material and hydraulic properties are considered to be uniform throughout each individual cell and are represented by the values at the node. The cells must fit together to smoothly and completely cover the whole region and the connections between nodes should be orthogonal, or very nearly orthogonal, to the intersecting cell interfaces. Developing reliable grids for irregular flow regions and subregions that satisfy these conditions offers a considerable challenge.

An interactive, graphics-based computer code, DIGRD, was developed at PNL by Foote, Rice and Kincaid (1982) to make grid development easier. DIGRD uses a RAMTEK scope, light pen, and digitizing table to construct grids, establish node connections, and move node locations and cell interface corners. Thus, the critical angles between node connections and the cell boundaries they intersect can be made as near to orthogonal as desired. 


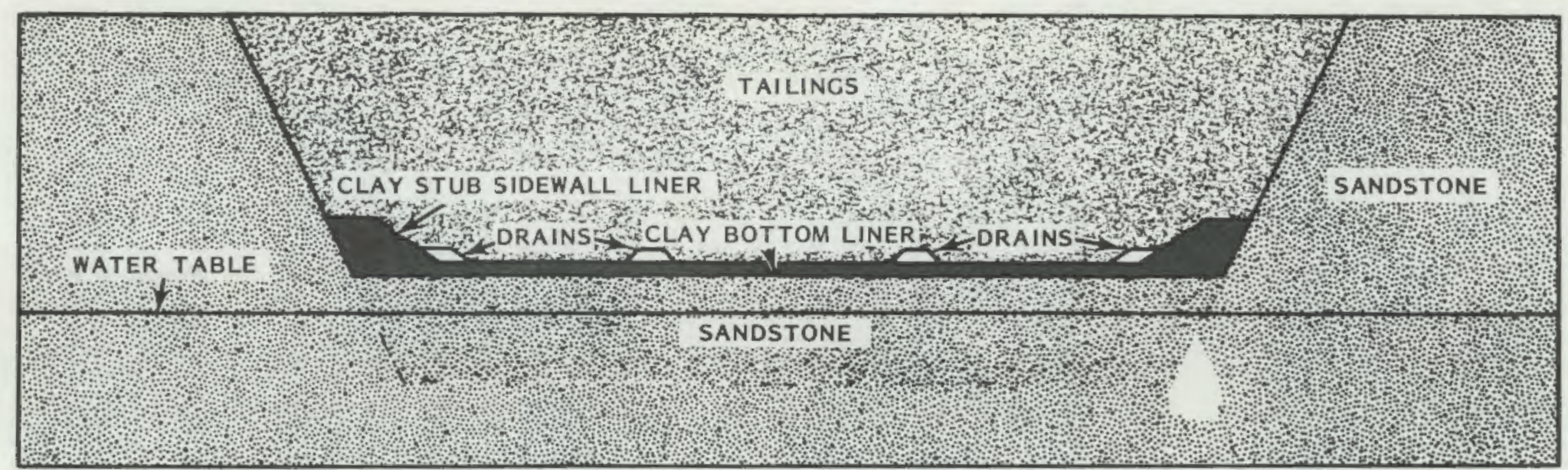

FIGURE 1a. Cross-Section of a Tailings Disposal Pit Above the Water Table -Uncovered (not drawn to scale)

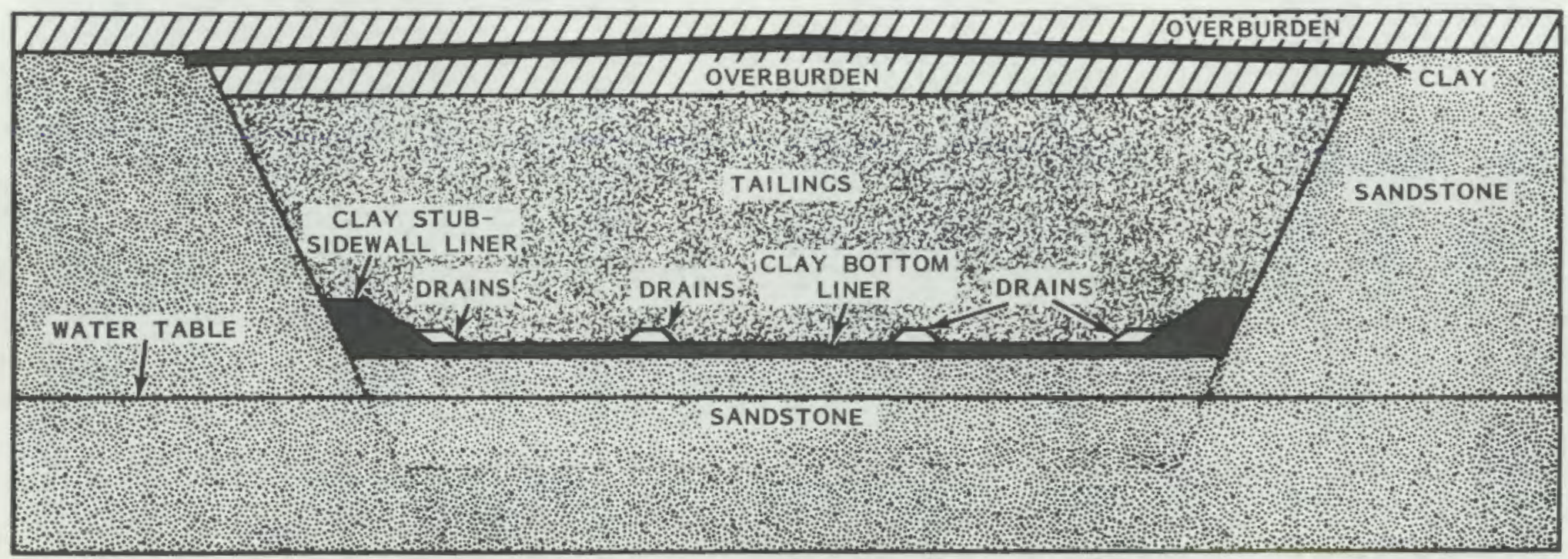

FIGURE 1b. Cross-Section of a Tailings Disposal Pit Above the Water Table -- Covered (not drawn to scale) 
During the course of this study, two different grids were used to simulate the seven cases. The right half of the first grid used is shown in Figure 2. For the case in which the water table was horizontal, the grid in Figure 2 could take advantage of the axis of symmetry about the vertical centerline of the tailings pit. For the remaining cases (with a sloping water table) we added a mirror image of this grid to the left of the centerline and changed the elevation of the nodes above the datum to reflect the sloping water table. This grid also allows us to consider the effects of a cover in the tailings pile.

Although the cover is an important feature in the long-term control of radon emission from the buried tailings, it can only be placed later in the simulation sequence. The tailings must drain and settle before a stable cover can be installed. Accordingly, a cover usually cannot be added until after a year or more into the simulation.

If future studies include analyses of precipitation and evapotranspiration, adding the cover may help to determine the ability of the clay layer to route the infiltration. A further impetus for adding the cover will exist once the TRUST code is modified to allow analyses of layered materials during consolidation. Because additional grid nodes are needed with the cover (28\% or more), resulting in increased computer costs, we did not use the cover in all of the cases.

Based on our experience with this first grid, we decided it was necessary to develop a new grid using the DIGRD generation program. By eliminating nodes where possible, we simplified the new grid.

The right half of the final grid is shown in Figure 3 ; the complete grid is symmetric. The main points followed in the design of this grid are:

- The grid is set up to handle any combination of the three control options: clay liner, clay stub-sidewall liner, and gravel-packed under-drains. The philosophy here is that any combination could be handled by changing the material associated with a given node rather than by changing the node configuration. Thus, simulation scenarios could be changed without inadvertently affecting the flow system through changes to the grid.

- The more regular grid (especially the rows of nodes at approximately the same elevation) allowed moisture content contours to be more representative. When nodes at different elevations in the unsaturated region have different potentials, contouring errors in moisture content develop because the soil-water characteristic curve is nonlinear.

- The top surface of the modeled region is at a uniform elevation because we did not consider a tailings cover in the final grid. 


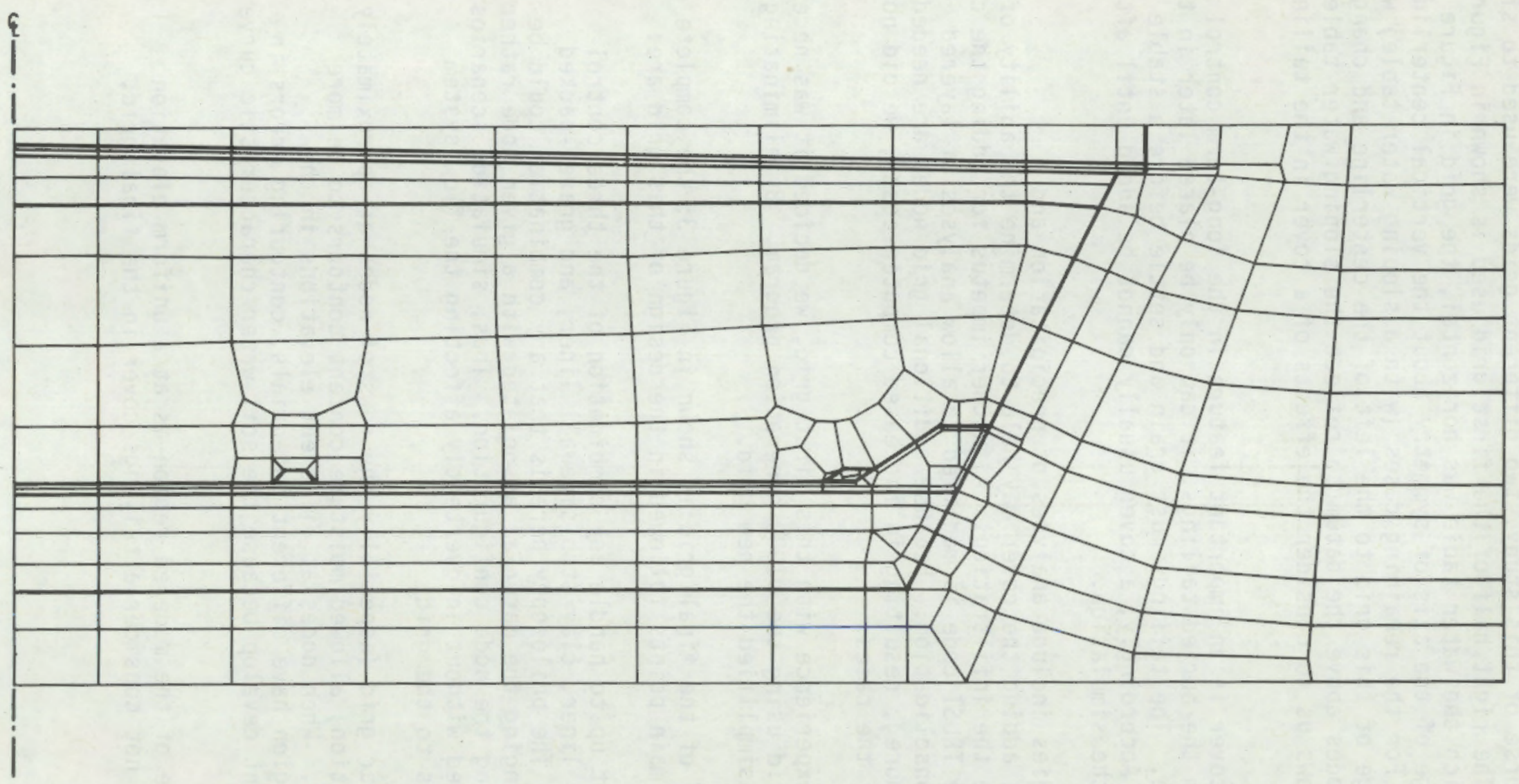

FIGURE 2. Right, or Upgradient, Half of TRUST Grid Number One 
๘

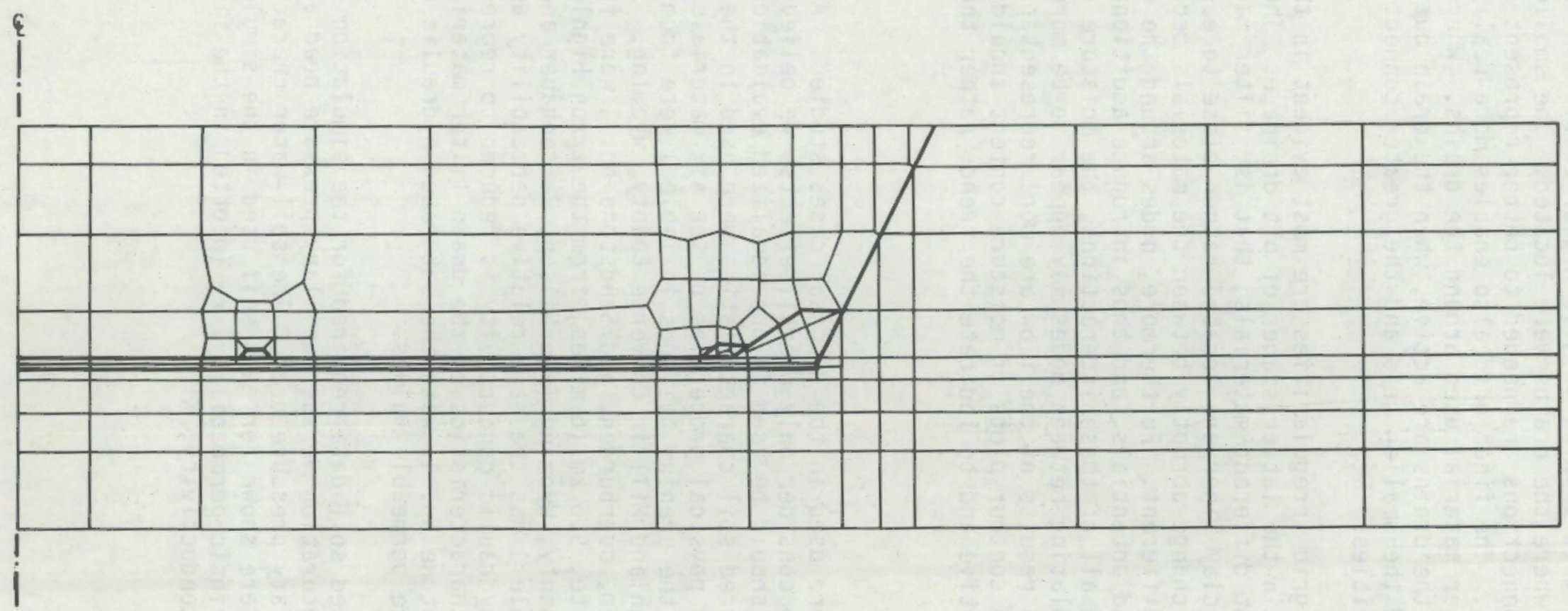

FIGURE 3. Right, or Upgradient, Half of TRUST Grid Number Two 
Both grids used small grid spacing to give higher resolution and better connectivity in the areas where the drains were located. The smaller grid spacings with more interconnections are needed to better represent the converging flow toward the drains. The finer grid also enables more-realistic simulation of the coarser filter material used around the drains. Whereas such resolution is needed when the drains are active, when the drain outflow stops or when no drains are used the smaller grid and the greater connectivity may cause noticeable irregularities.

The effects of these grid irregularities are most evident in the moisture content plots, especially in the latter stages of pit drainage. The nodes around the drains represent different materials; that is, filter material around the drains and the clay liner are located rather close to each other. The moisture contents may change abruptly between the materials because the characteristics are much different. Furthermore, nodes around the drains are at different elevations and potentials, and thus introduce additional changes in moisture content. With all of these interactions, the moisture content contours derived from interpolating between nodes may appear to be more irregular, even though the simulation results of the flow are more representative in these regions. Accordingly, the contour plots of moisture content should be considered to be only qualitative and to indicate the trend, rather than to provide exact detail.

\section{Soil Material Properties}

Six soil materials were used in the disposal cases studied. Although this evaluation was designed to consider only overall effects, we believed that realistic soil properties should be used in the idealized evaluations. Accordingly, predominantly measured soil characteristics were used in the seven cases. Table 1 summarizes physical properties of the six materials. The measured characteristics for the uranium tajlings in Table 1 were from tailings samples from the Exxon Highland Mill in Converse County, Wyoming. Samples measured for the clay liner, overburden, and Sandstone No. 1 were from the proposed Morton Ranch Mill Site, $9.6 \mathrm{~km}$ (6 miles) from the Exxon Highland Mill Site, again in Converse County, Wyoming (see Nelson, Reisenhauer and Gee 1980). The Sandstone No. 2 in Table 1 has the same relative permeability as Sandstone No. 1, but the saturated hydraulic conductivity is reduced to represent a less permeable material. The characteristics of the drain filter material were synthesized from the Sandstone No. 1, with the saturated hydraulic conductivity increased to represent more permeable values.

The partially saturated soil data required for the simulation consist of tabular values defining saturation versus capillary pressure head and intrinsic permeability versus capillary pressure head. The soil-water characteristic data points used in TRUST are shown for each soil used in the simulation in Figures 4 through 9. Intrinsic permeability, $k$, ( $p$ lotted in the figures) is related to the hydraulic conductivity, $k$ : 
TABLE 1. Selected Physical Characteristics for Soil Material Used in Model Cases

\begin{tabular}{|c|c|c|c|c|c|c|}
\hline \multirow[b]{2}{*}{ Characteristic } & \multirow[b]{2}{*}{ Tailings } & \multicolumn{2}{|c|}{ Sandstone } & \multirow[b]{2}{*}{ Clay Liner } & \multirow[b]{2}{*}{ Overburden } & \multirow{2}{*}{$\begin{array}{c}\text { Drain } \\
\text { Filter } \\
\text { Material } \\
\end{array}$} \\
\hline & & No. 1 & No. 2 & & & \\
\hline $\begin{array}{l}\text { Saturated } \\
\text { Conductivity } \\
\mathrm{K}(\mathrm{cm} / \mathrm{s})\end{array}$ & $2.2 \times 10^{-4}$ & $7.5 \times 10^{-3}$ & $1.0 \times 10^{-6}$ & $2.5 \times 10^{-8}$ & $1.3 \times 10^{-6}$ & $1.0 \times 10^{-1}$ \\
\hline $\begin{array}{l}\text { Particle } \\
\text { Density }\left(9 / \mathrm{cm}^{3}\right)\end{array}$ & 2.91 & 2.65 & 2.65 & 2.75 & 2.70 & 2.65 \\
\hline $\begin{array}{l}\text { Bulk Degsity } \\
\left(\mathrm{g} / \mathrm{cm}^{3}\right)\end{array}$ & 1.63 & 1.75 & 1.75 & 1.69 & 1.90 & 1.75 \\
\hline Void Ratio & 0.789 & 0.515 & 0.515 & 0.626 & 0.421 & 0.515 \\
\hline Porosity & 0.441 & 0.340 & 0.340 & 0.385 & 0.296 & 0.340 \\
\hline $\begin{array}{l}\text { Max. Compaction } \\
\qquad\left(g / \mathrm{cm}^{3}\right)\end{array}$ & $\cdots$ & $\cdots$ & $\cdots$ & 1.84 & 2.03 & -- \\
\hline
\end{tabular}

where $\rho$ is the fluid mass density, $g$ is the acceleration due to gravity, and $\mu$ is the dynamic viscosity of the fluid. Hysteresis was not considered in these simulations because data were limited. Also, experience has shown that much less hysteresis occurs under field conditions than is often reported for laboratory measurements.

\section{Results from Fluid Flow Analysis}

The results from the TRUST code provide at each time for each node the potential energy, capillary pressure, hydraulic conductivity, moisture content, and flux between each element. These large data sets are provided as time sequences on disk and magnetic tape for subsequent use, either to contour the resuits for display or to use in the transport analysis.

\section{TRANSPORT ANALYSIS}

The transport analysis uses the flow analysis results to determine the flow paths, arrival times, arrival locations, and amounts of transported constituents. The chemical interactions between individual constituents transported by the ground water and the porous materials should be included in a thorough transport analysis. The fluid movement effect, provided in the fluid flow analysis, is coupled in the transport analysis with the interactions of contaminants with the porous material and with the chemical reactions of individual constituents to provide the transport equations for the mixture of 


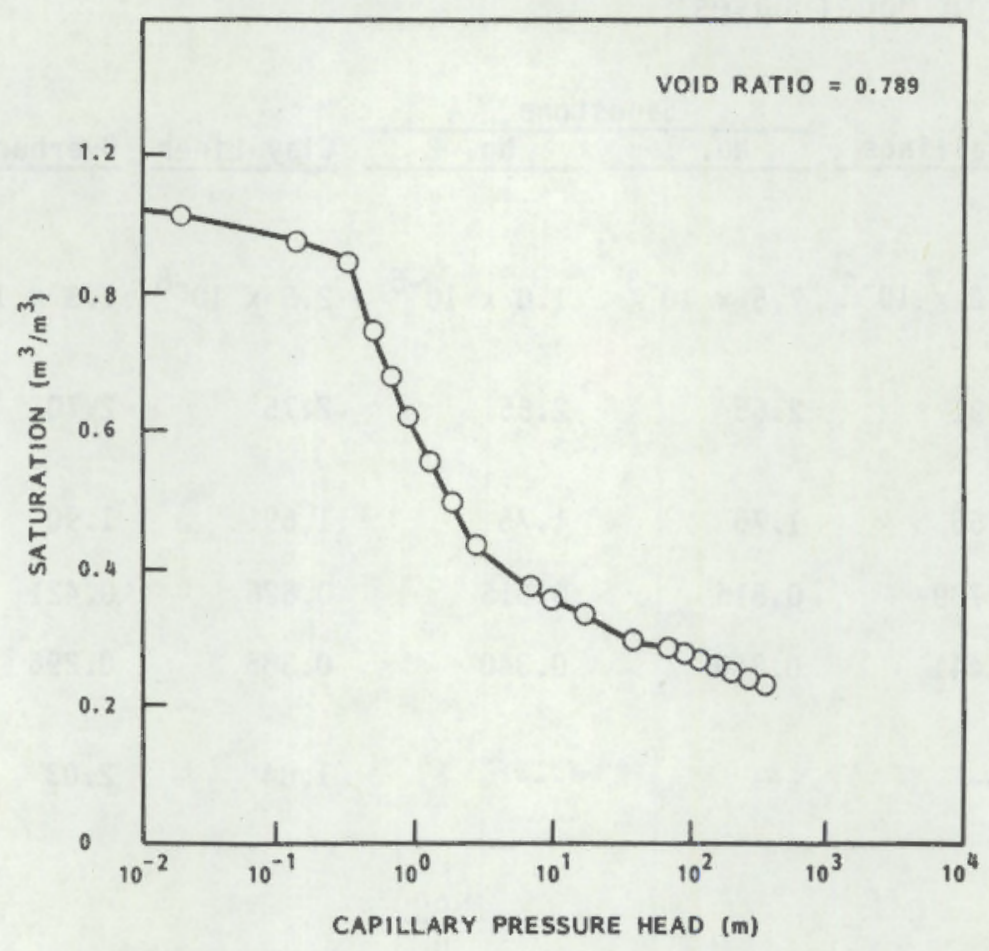

FIGURE 4a. Tailings Characteristic Saturation Curve

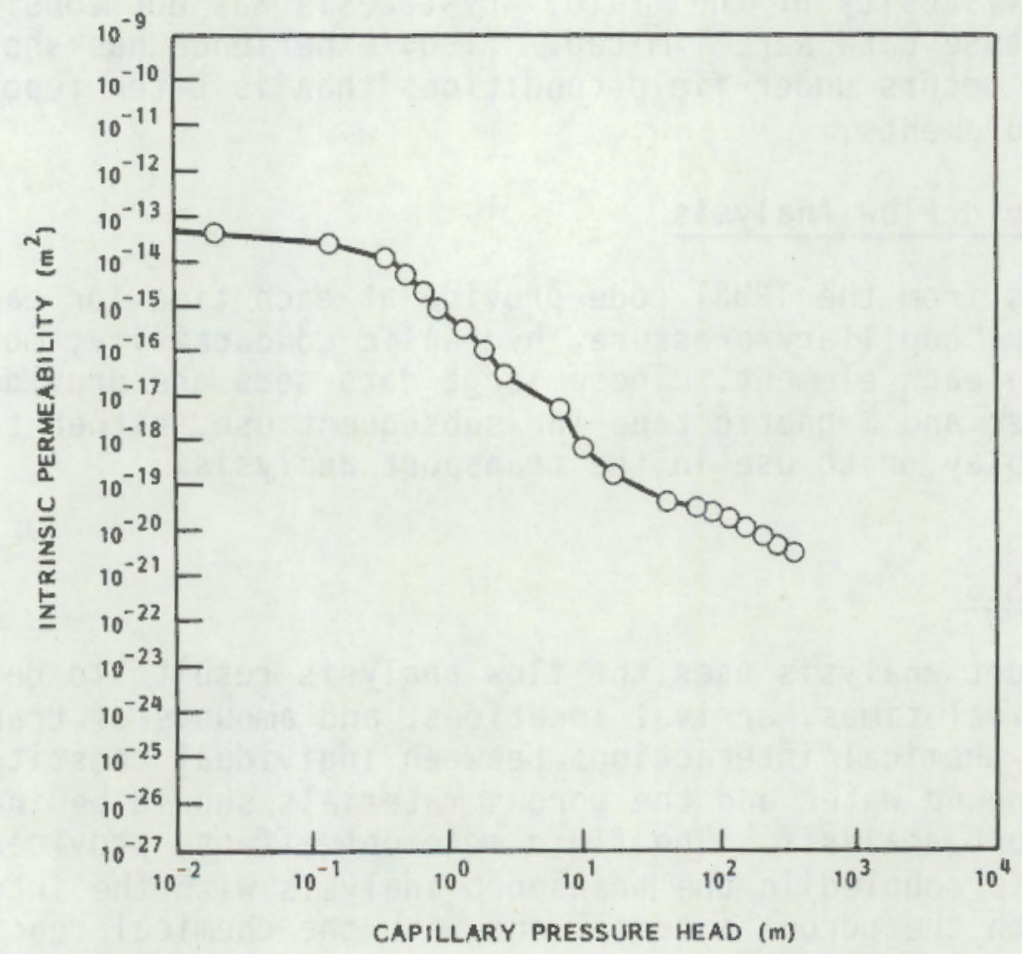

FIGURE 4b. Tailings Intrinsic Permeability Curve 


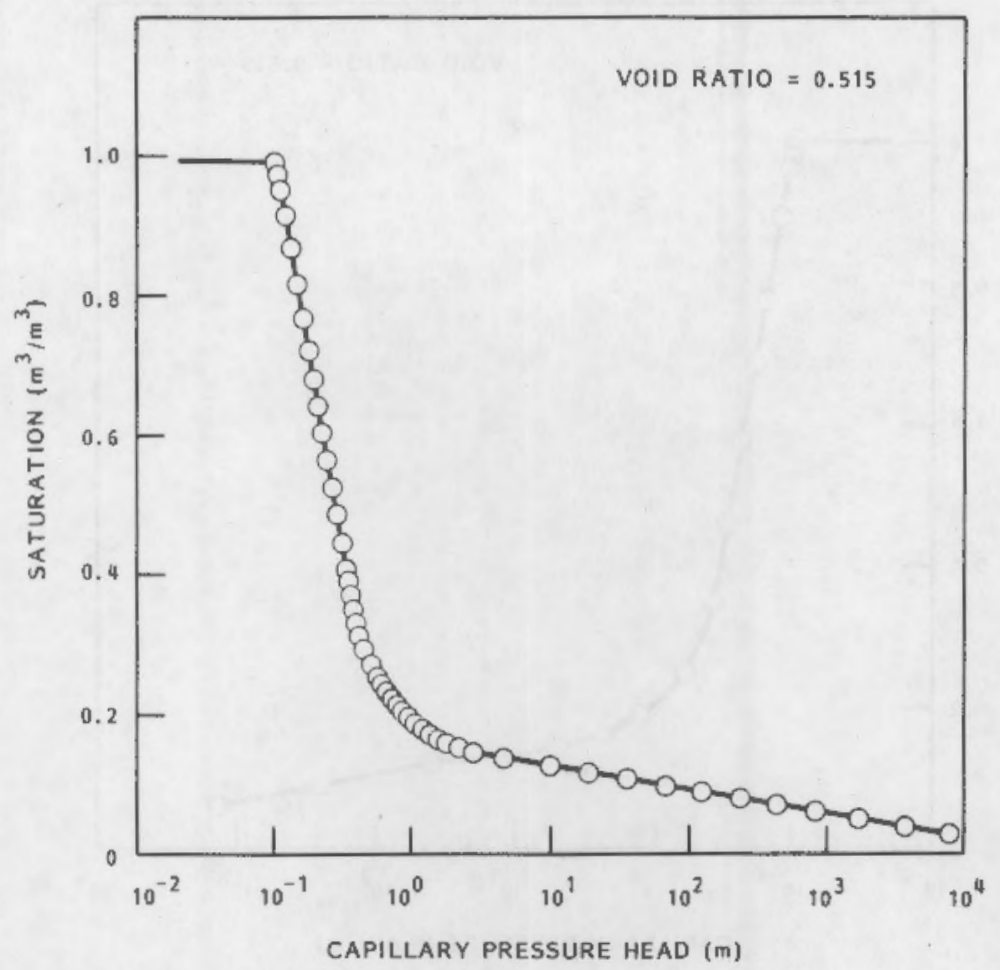

FIGURE 5a. Sandstone No.1 Characteristic Saturation Curve

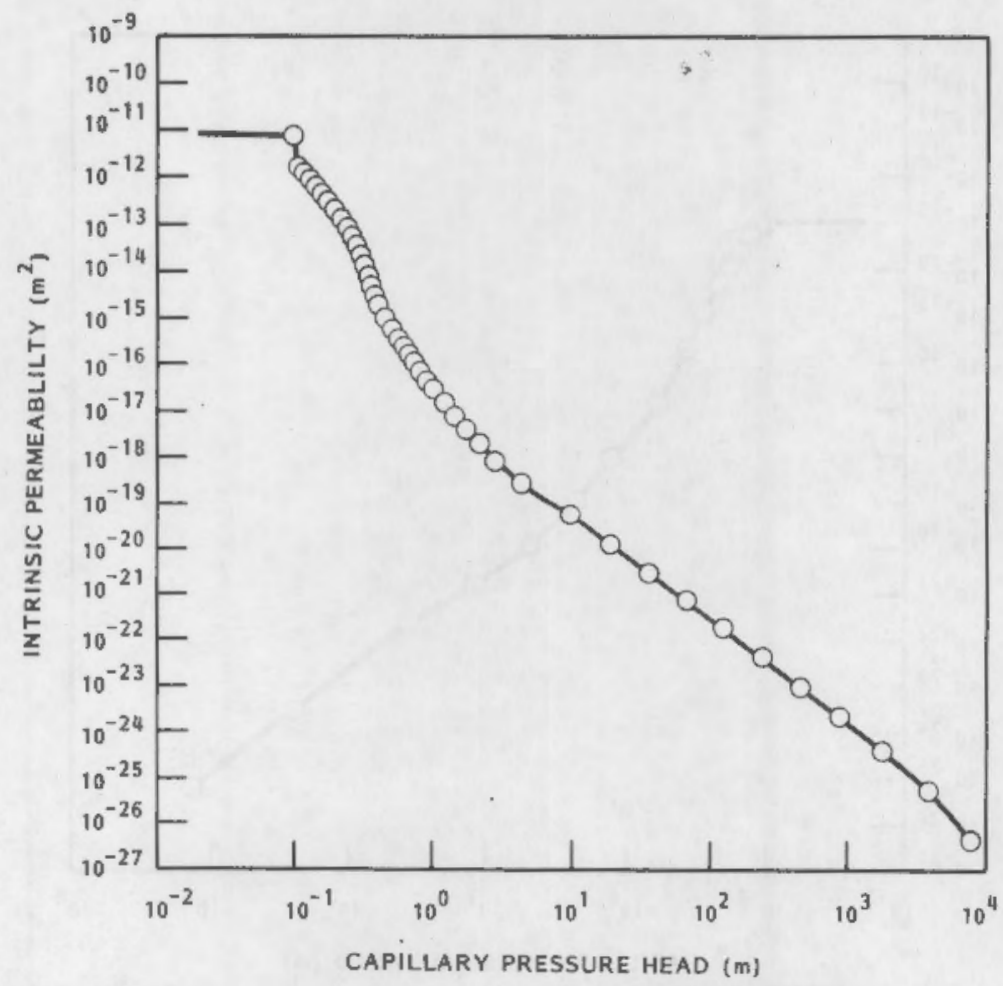

FIGURE 5b. Sandstone No. 1 Intrinsic Permeability Curve 


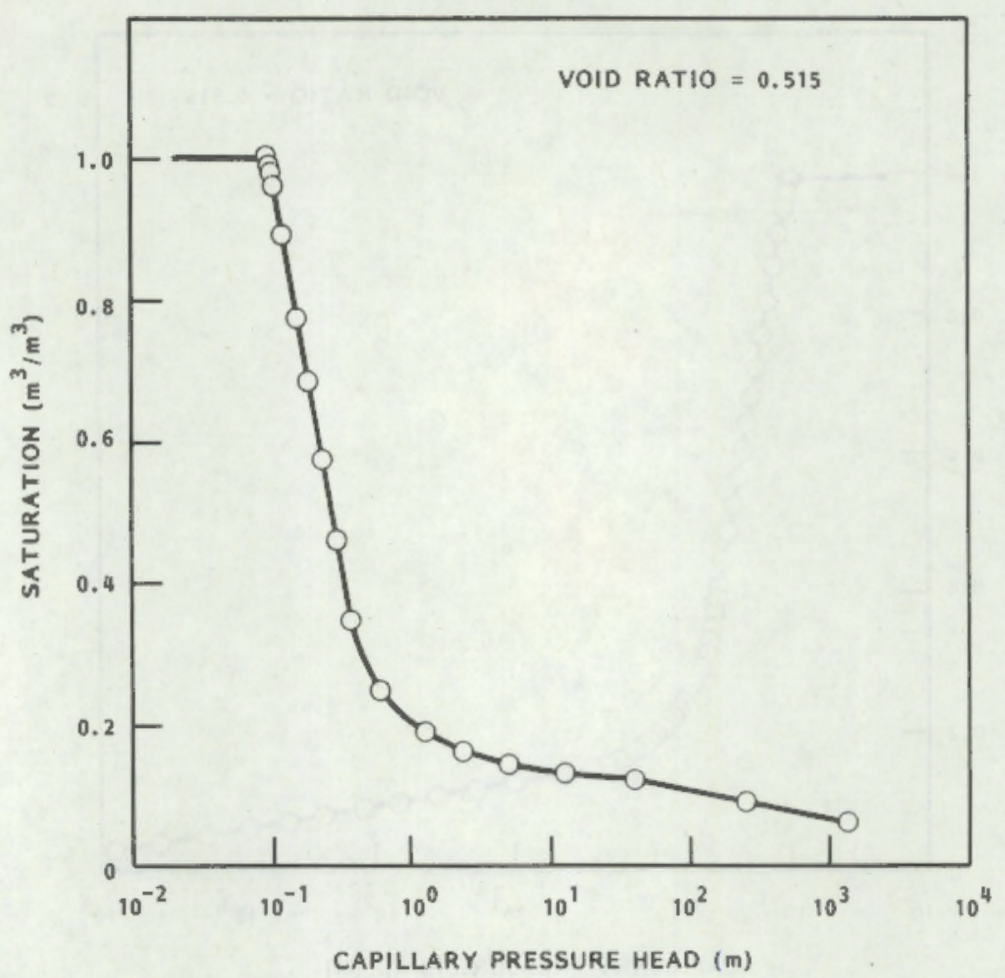

FIGURE 6a. Sandstone No. 2 Characteristic Saturation Curve

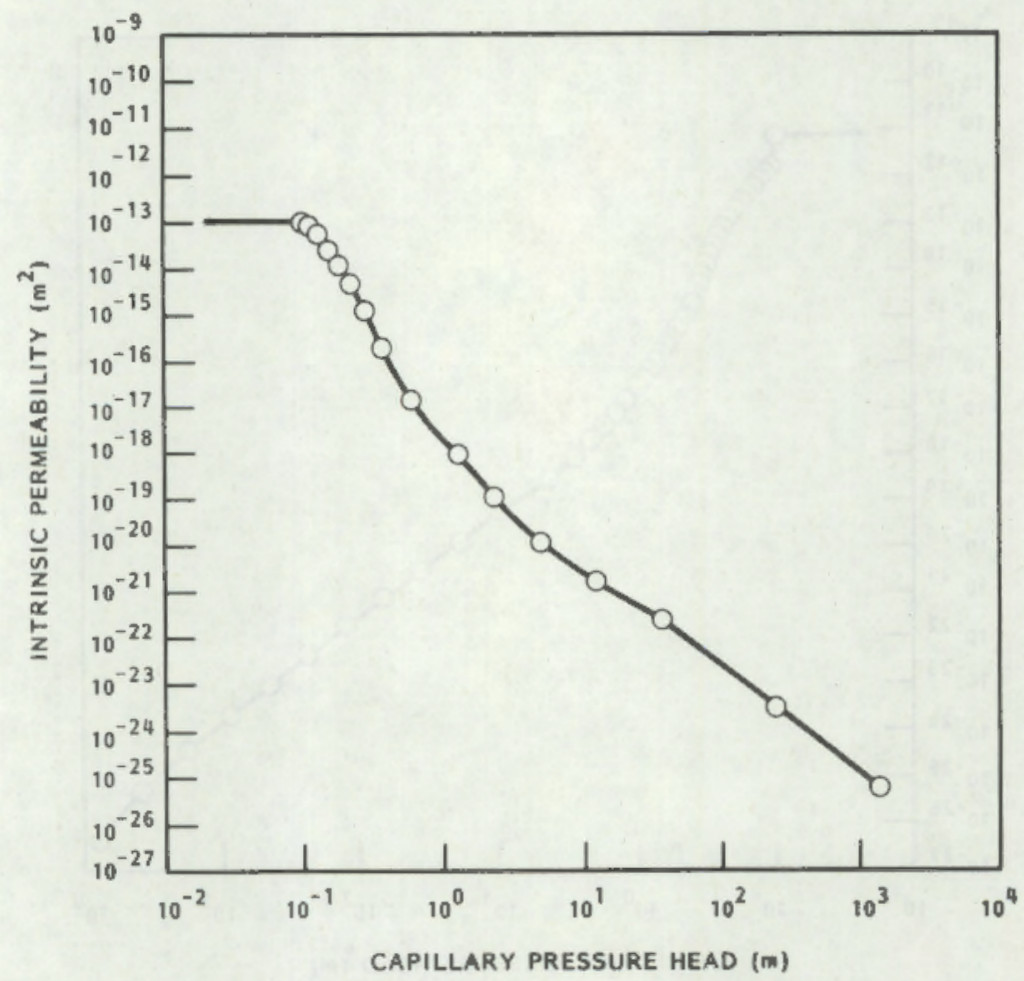

FIGURE 6b. Sandstone No. 2 Intrinsic Permeability Curve 


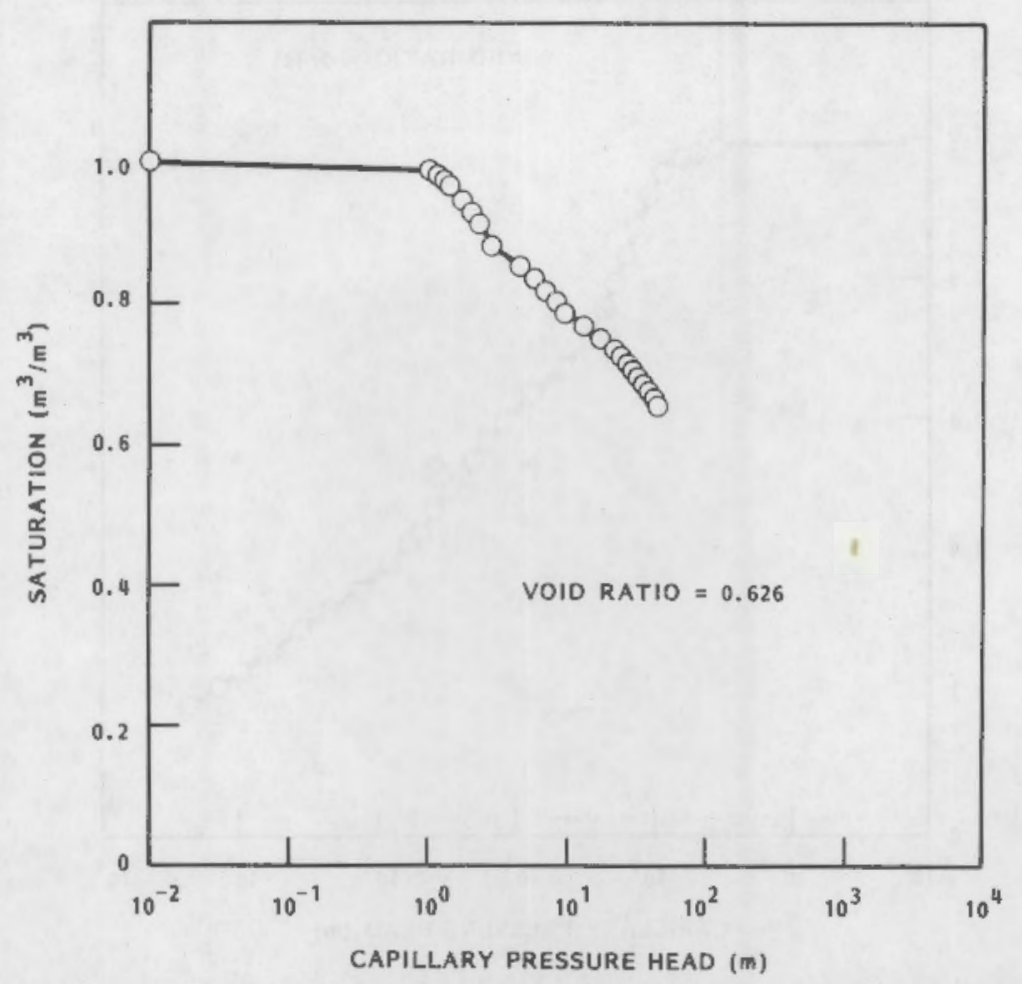

FIGURE 7a. Clay Characteristic Saturation Curve

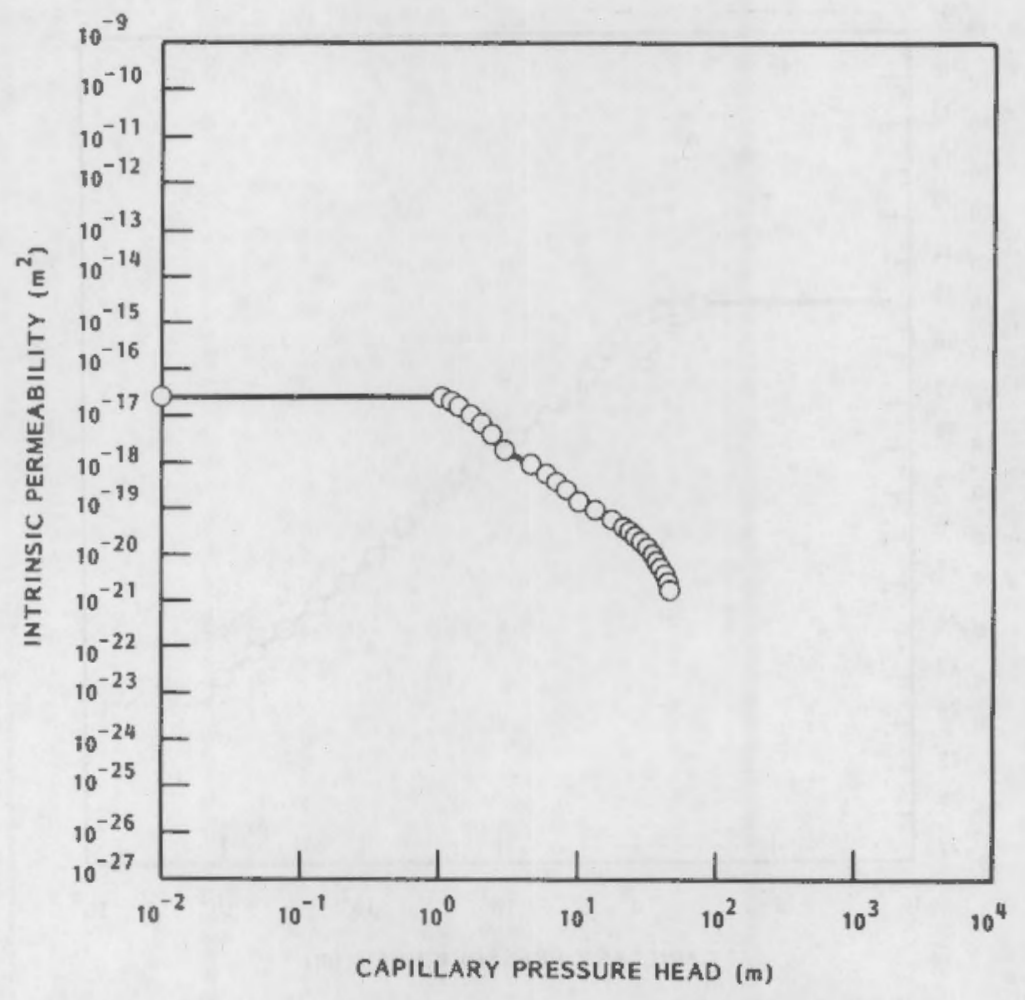

FIGURE 7b. Clay Intrinsic Permeability Curve 


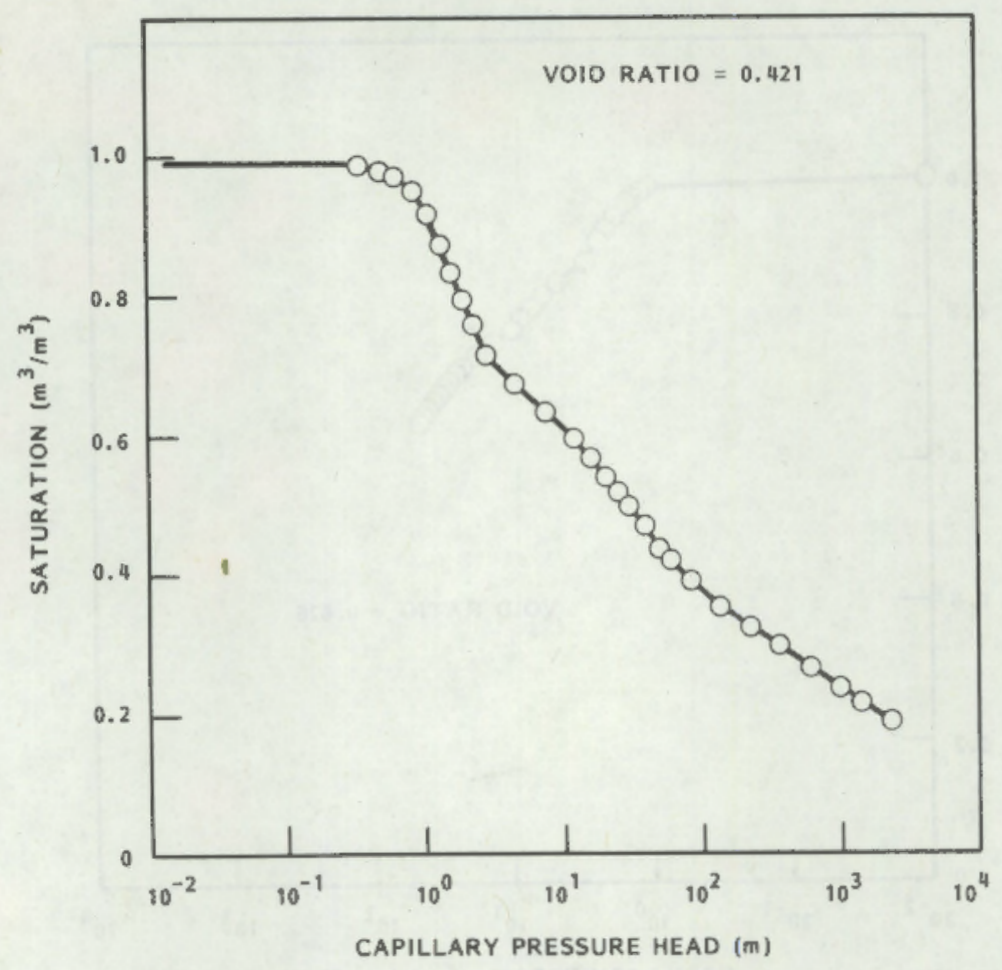

FIGURE 8a. Overburden Soil Characteristic Saturation Curve

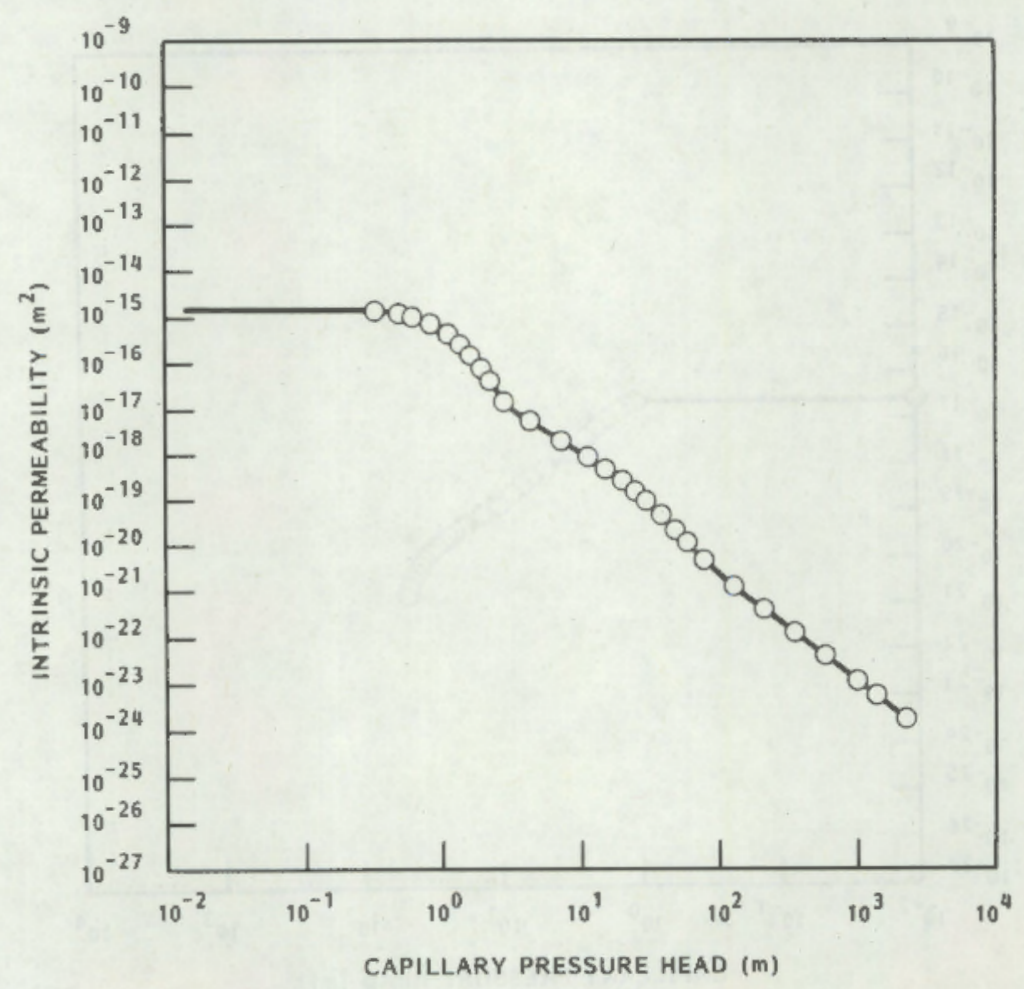

FIGURE 8b. Overburden Soil Intrinsic Permeability Curve 


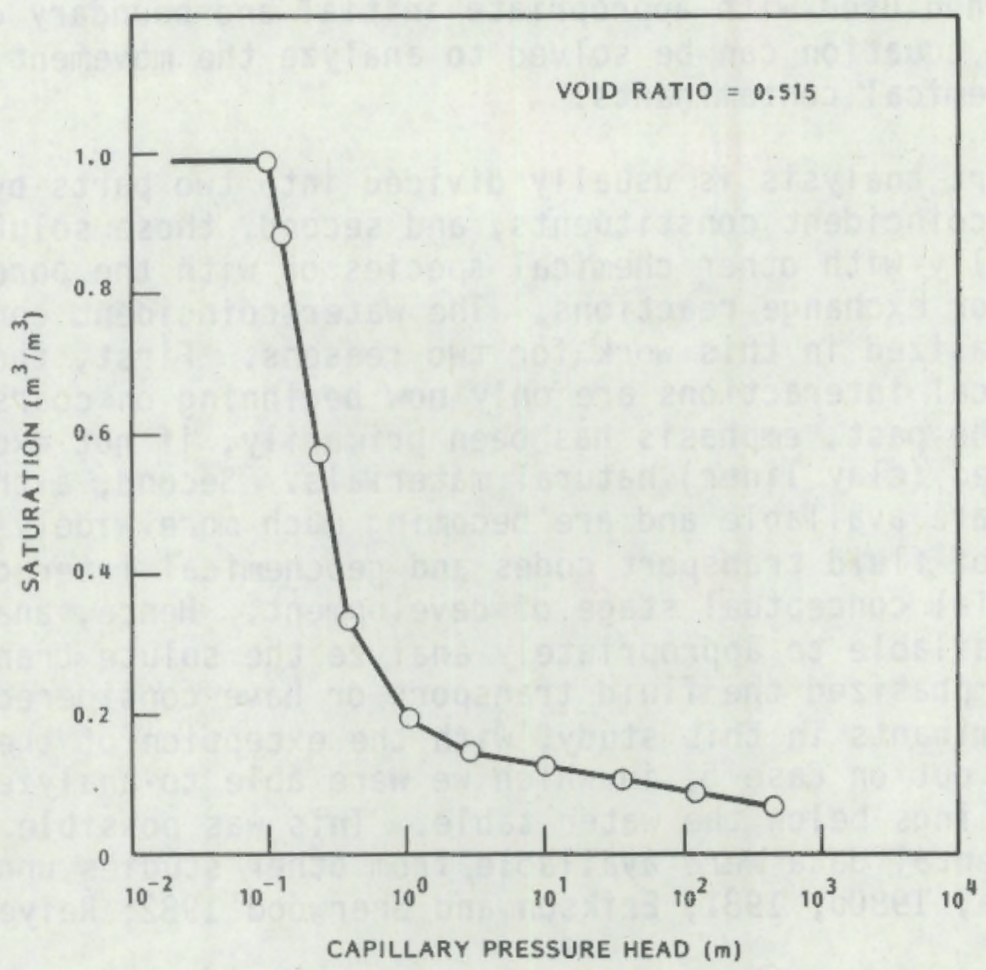

FIGURE 9a. Drain Filter Material Characteristic Saturation Curve

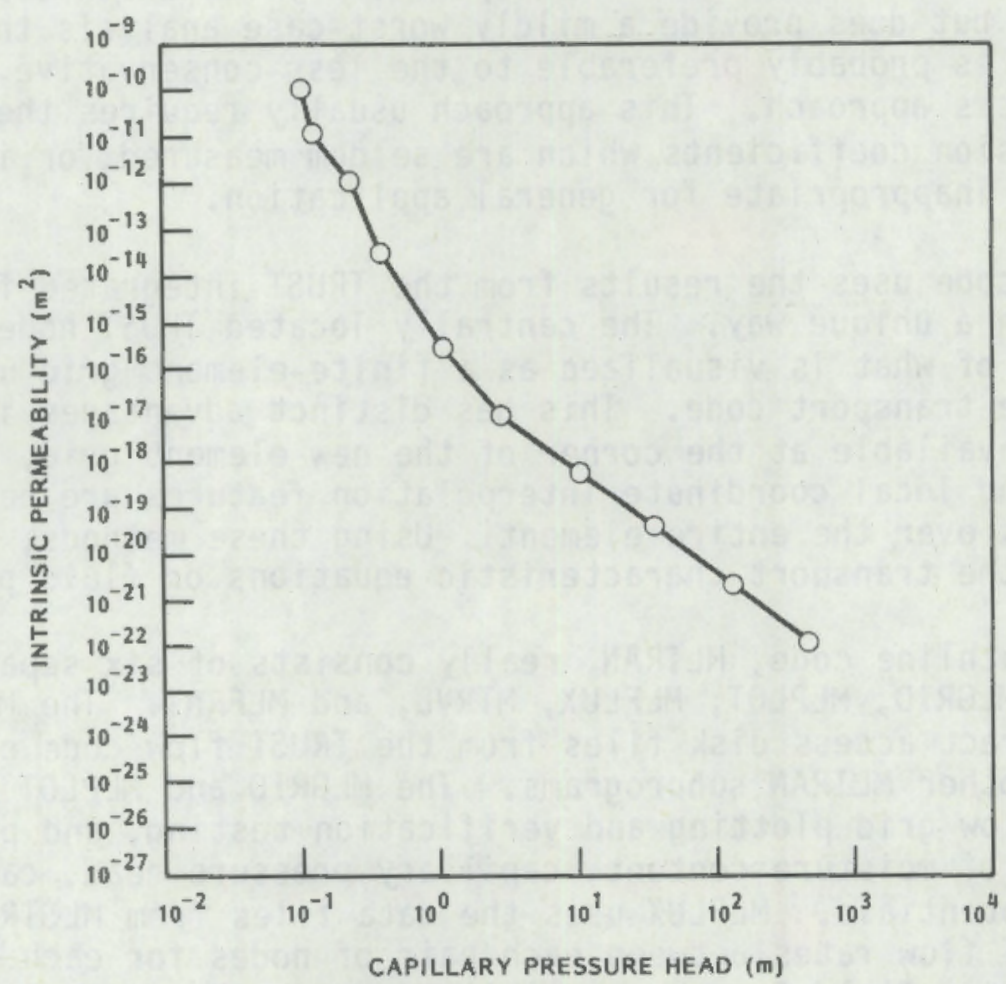

FIGURE 9b. Drain Filter Material Intrinsic Permeability Curve 
contaminants. When used with appropriate initial and boundary conditions, the solute transport equation can be solved to analyze the movement of individual components of chemical contaminants.

The transport analysis is usually divided into two parts by considering first the water-coincident constituents, and second, those solutes that either interact chemically with other chemical species or with the porous media through mineral or exchange reactions. The water-coincident constituents are necessarily emphasized in this work for two reasons. First, the experimental studies on chemical interactions are only now beginning on coarser, aquifer materials. In the past, emphasis has been primarily, if not exclusively, on the finer-textured (clay liner) natural materials. Second, although geochemical model codes are available and are becoming much more widely used, the actual coupling of fluid transport codes and geochemical interaction codes is only in the initial conceptual stage of development. Hence, analysis tools are not currently available to appropriately analyze the solute transport. Accordingly, we have emphasized the fluid transport or have considered only watercoincident contaminants in this study, with the exception of the detailed analysis carried out on Case 5, in which we were able to analyze leaching of sulfate from tailings below the water table. This was possible because some in-depth experimental data were available from other studies underway at PNL (Gee et al. 1980a, 1980b, 1981; Erikson and Sherwood 1982; Relyea and Martin 1982).

The MLTRAN code is used for the transport analysis. It is based on the method for convective deterministic transport analysis, which does not incorporate dispersion, but does provide a mildly worst-case analysis that is useful. Such an analysis is probably preferable to the less-conservative, convectivedispersion analysis approach. This approach usually requires the arbitrary choice of dispersion coefficients which are seldom measured; or if measured, they usually are inappropriate for general application.

The MLTRAN code uses the results from the TRUST integrated finite difference flow code in a unique way. The centrally located TRUST node points become the corner nodes of what is visualized as a finite-element grid used in the MLTRAN convective transport code. This has distinct advantages in that all of the results are available at the corner of the new element grid, and the finite-element and local coordinate interpolation features are easily applied to obtain results over the entire element. Using these methods, we can accurately generate the transport characteristic equations or fluid pathlines.

The fluid pathline code, MLTRAN, really consists of six separate subcodes: MLSTRT, MLGRID, MLPLOT, MLFLUX, MTRVL, and MLFRNT. The MLSTRT subcode generates the direct access disk files from the TRUST flow code output that are used by the other MLTRAN subprograms. The MLGRID and MLPLOT are utility routines that allow grid plotting and verification testing, and provide the graphical output of moisture content, capillary pressure head, capillary conductivity, and potentials. MLFLUX uses the data files from MLSTRT (which include the TRUST flow rates between each pair of nodes for each time) to calculate the vector field for the spatial and temporal pore velocity. MLFLUX 
may also be used to generate retarded velocity fields, given the pH buffering capacities or retardation characteristics of material. From these velocity fields $\mathrm{pH}$ and sorbed ion front advances may be determined. The subprogram MLTRVL determines the pathlines and calculates the travel times along those flow paths using the pore velocity fields from MLFLUX. The last subprogram, MLFRNT, allows the advancing contamination fronts to be plotted using the results from several sequentially determined pathlines from MLTRVL. Unfortunately, the MLTRAN code as developed at present, must be documented so it can be made available other users. This useful code is currently operated on a mini-computer (DEC PDP 11/70).

As mentioned, the MLTRAN code provides the flow paths of the fluid, originating at a selected coordinate locaton at a particular time. The pathlines follow the trajectory traversed by particles of that particular fluid. If fluid particles originating in the tailings are followed, the course traversed by the leachate into the water table and away from the tailings pit is easily identified. Through judicious use of these results in combination with the TRUST flow results, we can determine the amounts and concentration of leachate leaving the pits. Thus, disposal above and below the water table for the various control methods can be compared. 



\section{DISPOSAL CASES ABOVE THE WATER TABLE}

The four cases discussed in the following subsections investigate the effect of uranium mill tailings disposal above the water table. The first three cases consider a sloping water table in which the vertical cross-section is oriented downgradient; the fourth case involves a static water table with no ground-water gradient.

Case 1 involves no control measures for reducing leachate losses. A clay bottom liner was installed for Case 2. For Case 3, pumping from the drain sumps, and clay stub-sidewall liners were added. The fourth case for disposal above the water table is the same as Case 3 , except there is no water-table gradient.

\section{REFERENCE CASE 1}

Case 1 probably represents the worst situation for disposal above the water table, with no control measures used. Only two materials, the Sandstone No. 2 (Figure 6) and the uranium mill tailings, are involved. Grid No. 2 (see Figure 3) was used for this reference case. The pit bottom is $16.6 \mathrm{~m}$ (58 ft) above the aquifer bottom and $3.05 \mathrm{~m}(10.0 \mathrm{ft})$ above the water table. The regional ground water flows from right to left with a regional gradient of 0.005 . The grid is oriented with the natural gradient and is maintained with the end boundaries held at a potential equal to the water-table elevation at the respective ends of the flow system. The fluid or hydraulic potential is expressed as energy per unit weight of fluid and is reported in units of meters of water head.

\section{Fluid Flow Analysis}

The distribution of the initial and final fluid potential for the Reference Case 1 from the TRUST code is shown in Figures $10 \mathrm{a}$ and 10b. The initial potential head is higher in the pit because of the completely saturated tailings. Also, there is a gradient of head across the pit from the right to the left (see Figure 10a). A similar gradient from the right toward the left is seen in the saturated zone below the water table beneath the tailings. The initial and final values of the moisture distribution are shown in Figures 11 a and 11b. Note the sharp contrast between the initially saturated tailings at a moisture content in the pit of 0.44 in Figure lla compared to the almost equilibrium of the drained tailings at moisture contents of 0.15 and 0.16 in Figure 11b. Additional plots of the fluid potential and moisture contents during the intermediate times of drainage in the tailings pit are provided in Appendix B.

Three distinct phases of flow occurred in the simulation of Case 1 . The first phase included approximately the first 1500 days ( 4.1 years). During this time, water slowly saturates the region between the tailings and the water table (indicated as the region of sharp moisture change between moisture 


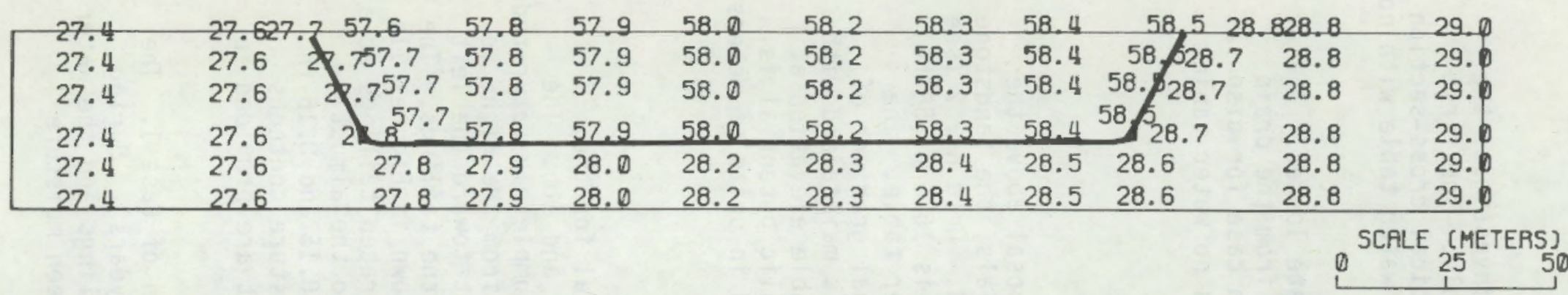

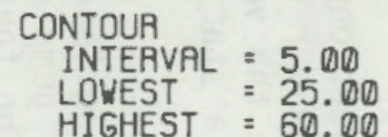

FIGURE 10a. Initial Hydraulic Potential Contours--Above The Water Table, Reference Case 1 (values in meters)

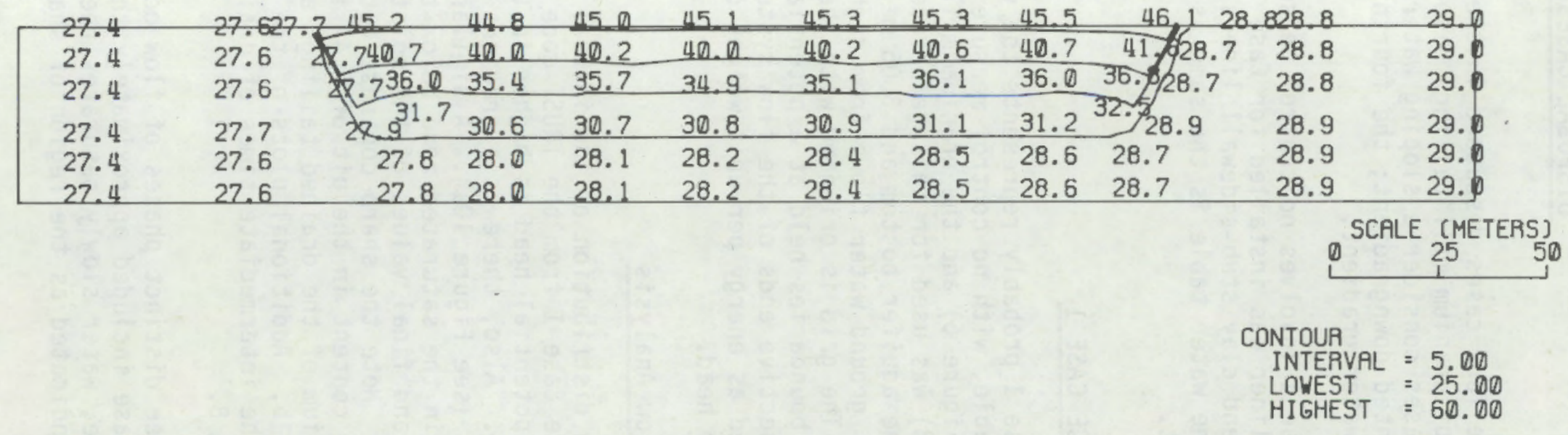

FIGURE 10b. Final Hydraulic Potential Contours--Above The Water Table, Reference Case 1 (values in meters) 


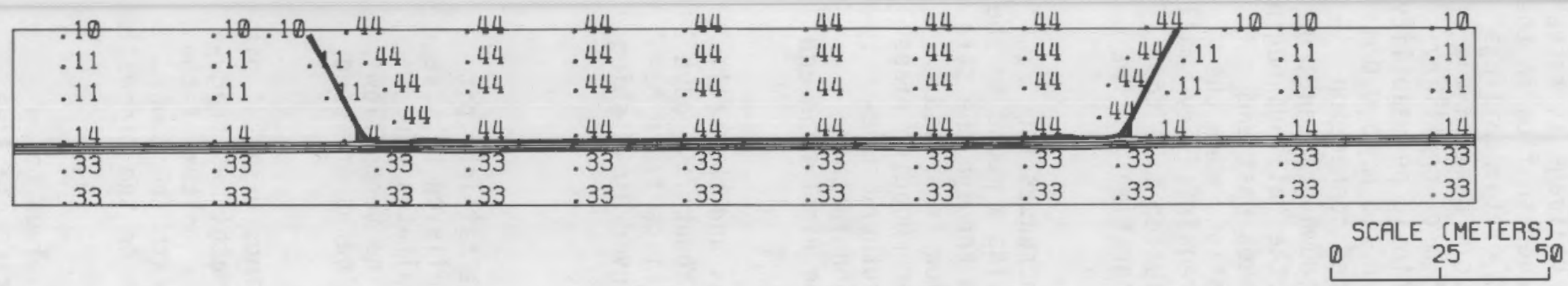

CONTOUR

INTERVAL $=.05$

LOWEST $=.10$

HIGHEST $=.45$ FIGURE 1la. Initial Moisture Content Contqurs--Above The Water Table,
Reference Case 1 (values in $\mathrm{m}^{3} / \mathrm{m}^{3}$ )

$\tilde{\omega}$

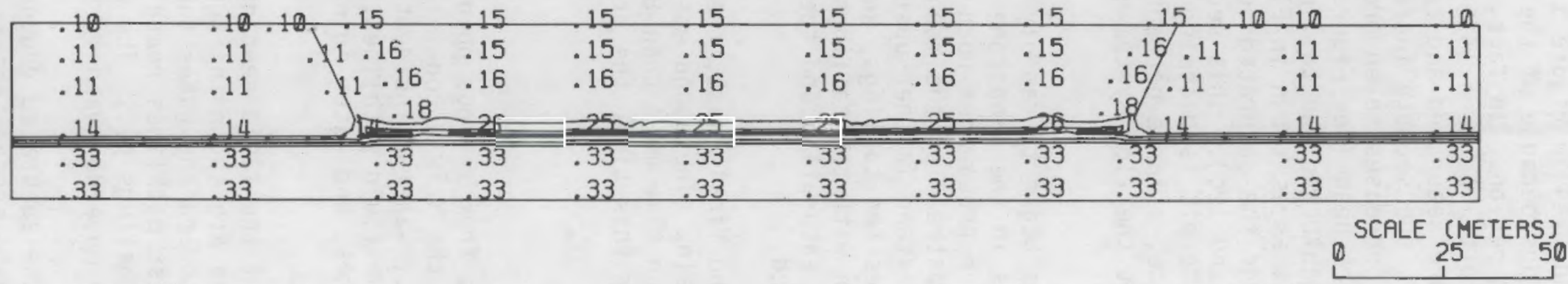

CONTOUA

INTEAVAL $=.05$

LOWEST $=.10$

HIGHEST $=.45$

FIGURE 11b. Final Moisture Content Contours--Above The Water Table, Reference Case 1 (values in $\mathrm{m}^{3} / \mathrm{m}^{3}$ ) 
contents of 0.33 and 0.44 in Figure 11a). During this time, drainage is rather slow from the tailings because of the moderately high resistance to flow in the partially saturated region. In fact, at 1435 days, only $0.4 \%$ of the tailings fluid has left the pit. Between 1435 and 1500 days, as the soil beneath the tailings becomes more saturated and reaches approximately $0.5 \mathrm{~m}$ of capillary pressure and higher, the seepage increases rapidly. The intrinsic permeability of Sandstone No. 2 increases seven orders of magnitude between $0.5 \mathrm{~m} \mathrm{to} 0.0 \mathrm{~m}$ in'capillary pressure head (see Figure 6b). The more saturated connection between the water table and the tailings occurs first at the down-gradient, or left, end of the pit as is shown in Figure 12a. At that end the tailings begin draining rapidly, and the saturated connection gradually spreads upstream (Figures 12a, 12b, and 12c). This second phase of the simulation, when the sandstone beneath the pit is becoming completely saturated, requires very small time steps, and hence, a large percentage of the computer solution time to accurately represent the flow system (53\% of the total computer time for the 60-day period).

As the tailings begin to rapidly drain, that drainage increases the hydraulic potentials in the sandstone beneath the pit and builds a mound in the saturated zone, which propagates both upstream and downstream through the saturated sandstone. Upstream of the mound the regional water flow is slowed, which causes it to extend farther upstream. This ground-water mounding rises toward and approaches the tailings, and thus helps to form another, morepermeable connection with the tailings. The unsaturated region farther upstream approaches saturation and the cycle repeats until the right-hand end of the pit is reached.

In the third and final phase, the mound gradually recedes and the tailings continue to drain. The mound essentially disappears by about 7000 days (19.2 years) by which time more than $81 \%$ of the drainable tailings fluid has left the pit. After this time, the drainage continues at an ever-diminishing rate.

Transport Analysis

Transport paths from various points along the edge of the tailings pit were generated with the MLTRAN code. Contaminants that are believed to move with the fluid (i.e., water-coincident constituents such as sulfates and chlorides) follow the fluid pathlines. (In this discussion, the terms flow paths, fluid pathlines, and water-coincident contaminant flow paths are used interchangeably).

The pathlines of the fluid seeping from the unlined tailings disposal pit above the water table are shown in Figures $13 a$ and $13 b$. The pathlines gradually move downward toward the water table from along the entire bottom of the pit, with the earliest pathlines reaching the water table beneath the lowerleft corner of the tailings pit. The pathlines that originate on the sidewalls of the pit primarily move downward in the tailings.

The effect of the saturated ground-water mound, which develops below the pit as the leachate seepage enters the water table, is noticeable (see Figure 13b). The pathlines in Figure 13b actually move upstream to the right, 


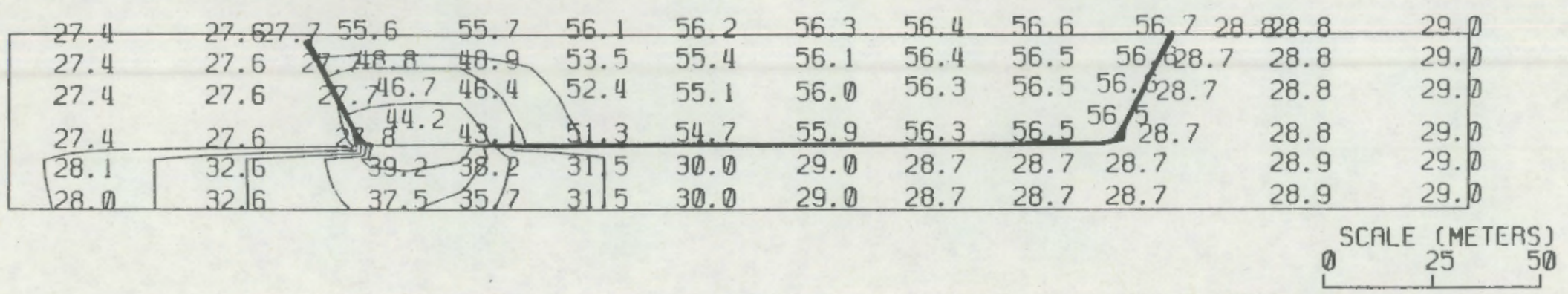

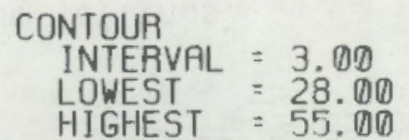

FIGURE 12a. Hydraulic Potential Contours at 1523 Days as Major Tailings Fluid Outflow Occurs at Lower End of the Pit

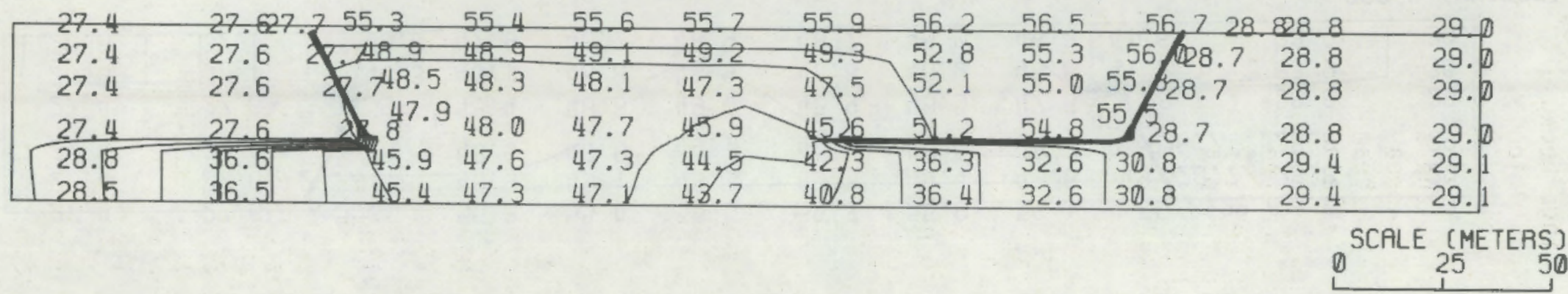

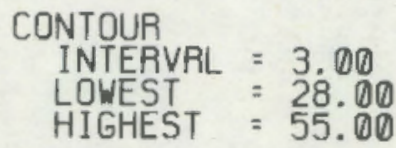

FIGURE 12b. Hydraulic Potential Contours at 1544 Days as Tailings Fluid Outflow Expands Upgradient Along Pit 


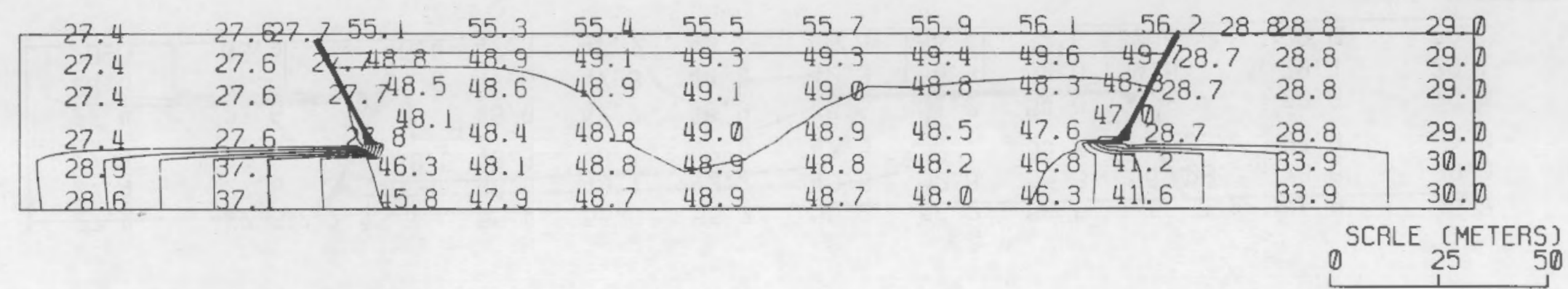

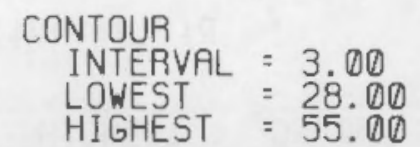

FIGURE 12C. Hydraulic Potential Contours at 1577 Days at Maximum Tailings Fluid Outflow from the Pit 


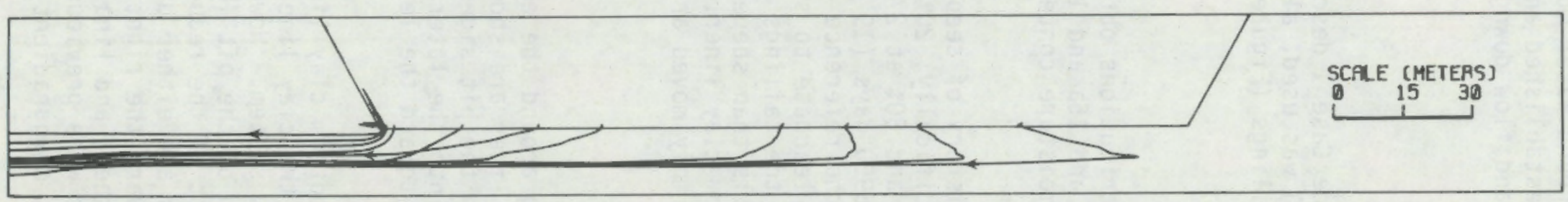

FIGURE 13a. Transport Pathlines--Above The Water Table, Reference Case 1 (Departure Time $=0$ days)

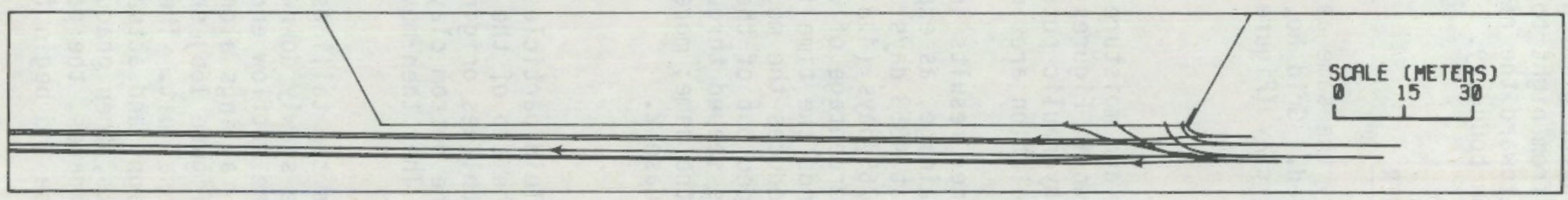

FIGURE 13b. Additional Pathlines--Above the Water Table, Reference Case 1 (Departure Time $=0$ days) 
against the original ground-water gradient. As the ground-water mound diminishes, the natural gradient from right to left is re-established and the pathlines that have been moving toward the right reverse and flow downgradient toward the left-hand, outflow boundary.

\section{CASE 2--WITH CLAY BOTTOM LINER}

This case is essentially the same as the Reference Case 1 described above, with a clay bottom liner added. Grid No. 2 (Figure 3) was used, along with the material characteristics for clay (Figure 7), mill tailings (Figure 4), and Sandstone No. 2 (Figure 6).

Fluid Flow Analysis

The hydraulic potential and moisture content distributions obtained by using the TRUST code are shown in Figures $14 \mathrm{a}$ and $14 \mathrm{~b}$ and $15 \mathrm{a}$ and $15 \mathrm{~b}$. Additional distributions of the hydraulic potentials and moisture contents at various times during the simulation are in Appendix $C$.

In general, the clay liner results in a longer history of seepage from the mill tailings with slower drainage, as expected. Specifically, $20 \%$ of the drainable fluid was drained at 4853 days (13.3 years) and $80 \%$ at 27,753 days ( 76 years), as compared to 1765 days ( 4.8 years) and 6950 days ( 19 years), respectively, for the same percentage of drainage in the reference case. The clay liner considerably extends the time for tailings leachate to seep from the disposal pit and generally reduces the mounding below the tailings pit. At the same time, more leachate seeped out of the pit sidewalls than seeped out in the Reference Case 1 because less seeped through the bottom clay liner. The overall leachate loss was about the same; more leachate simply moved around the end of the bottom clay liner in Case 2 .

Transport Analysis

The pathlines for the fluid particles originating around the edge of the disposal pit and along the top of the botton clay liner are shown in Figures 16a and 16b. The pathlines originating low on the pit sidewalls move downward around the end of the bottom clay liner and into the lateral flow of the saturated ground-water. They then move laterally toward the left-hand outflow boundary.

Pathlines originating in the tailings above the bottom clay liner toward the left half of the pit move slowly downward through the clay liner and then gradually flow left toward the outflow end of the flow system. However, fluid particles originating in the tailings along the bottom of the pit (but toward the right end of the pit in Figure 16b) show the effect of the reduced mound that develops below the disposal pit. These pathlines are either diverted downward or further to the right and actually flow toward the right while the water-table mound grows, peaks, then gradually diminishes, and finally vanishes. As the mound dissipates, the pathlines that were previously moving to the right gradually reverse and begin flowing left, downgradient toward the outflow boundary. 


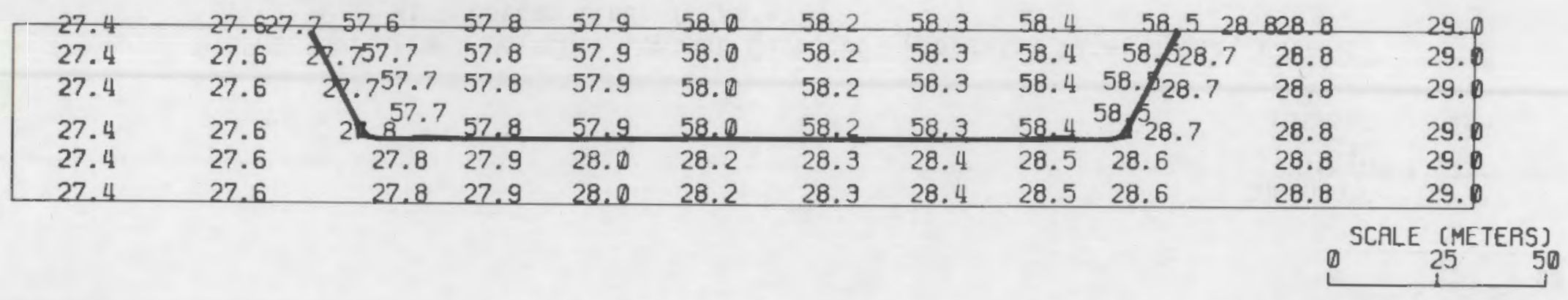

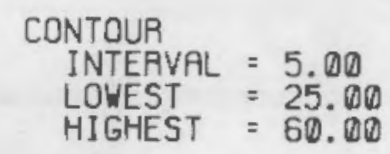

FIGURE 14a. Initial Hydraulic Potential Contours--Above The Water Table, Case 2 with Clay Bottom Liner (values in meters)

\begin{tabular}{|c|c|c|c|c|c|c|c|c|c|}
\hline 27.4 & 27.62 & -44.8 & 44.4 & 44.5 & 44.7 & 44.8 & 44.9 & $45 \mathrm{~A}$ & \\
\hline 27.4 & 27.6 & .240 .3 & 39.7 & 39.8 & 39.7 & 39.8 & 40.2 & 40.3 & \\
\hline 27.4 & 27.6 & 8.235 .7 & 35.2 & 35.4 & 34.7 & 34.8 & 35.8 & 35.8 & \\
\hline 27.5 & 27.7 & 28.1 & 30.8 & 30.8 & 31.0 & 31.1 & 31.2 & 31.4 & $\int 25$ \\
\hline 27.4 & 27.6 & 27.9 & 28.0 & 28.1 & $2 B .2$ & 28.4 & 28.5 & 28.6 & 28.7 \\
\hline 27.4 & 27.6 & 27.9 & 28.0 & 28.1 & 28.2 & 28.4 & 28.5 & 28.6 & 28.7 \\
\hline
\end{tabular}

$\begin{array}{ll}828.8 & 29.9 \\ 28.8 & 29.0 \\ 28.8 & 29.0 \\ 28.9 & 29.0 \\ 28.9 & 29.0 \\ 28.9 & 29.0\end{array}$
$0^{\text {SCRLE (METEAS) }}$

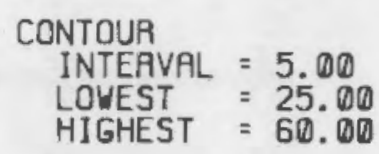

FIGURE 14b. Final Hydraulic Potential Contours--Above The Water Table, Case 2 with Clay Bottom Liner (values in meters) 


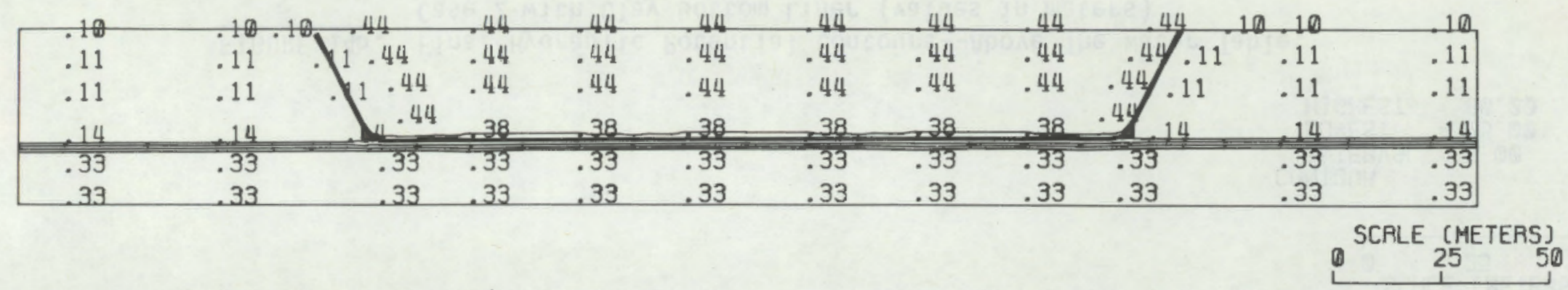

CONTOUR

INTERVAL $=.05$

LOWEST $=.10$

HIGHEST $=.45$

FIGURE 15a. Initial Moisture Content Contours--Abqve The Water Table, Case 2 with Bottom Liner (values in $\mathrm{m}^{3} / \mathrm{m}^{3}$ )

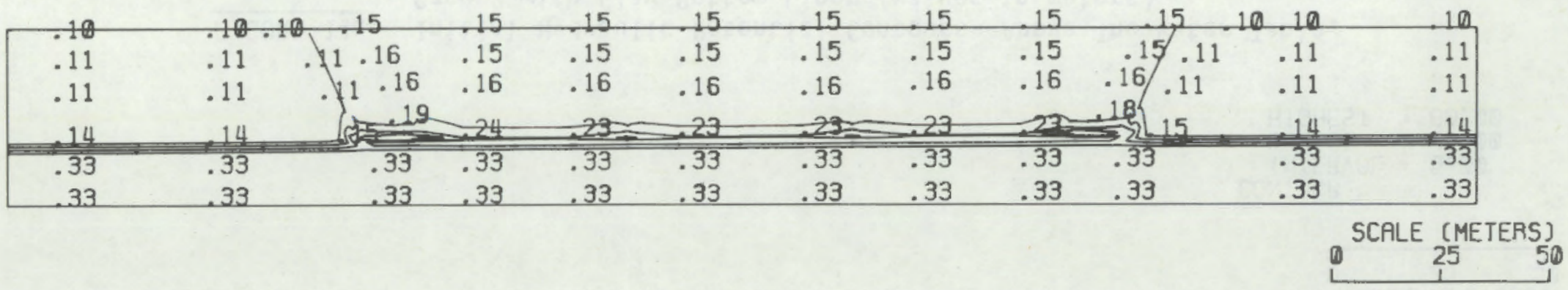

CONTOUR

INTERVAL $=.05$

LOWEST $=.10$

HIGHEST $=.45$

FIGURE 15b. Final Moisture Content Contours--Above The Water Table, Case 2 With Bottom Liner $\left(\mathrm{m}^{3} / \mathrm{m}^{3}\right)$ 


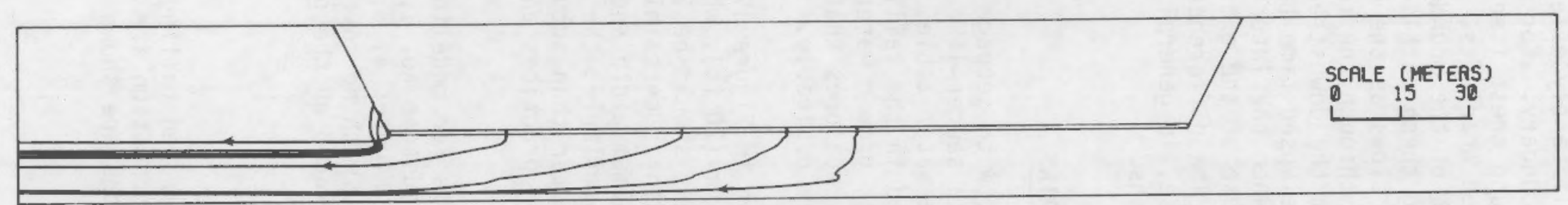

FIGURE 16a. Transport Pathlines for Case 2 with Clay Bottom Liner

$\stackrel{\omega}{\omega}$

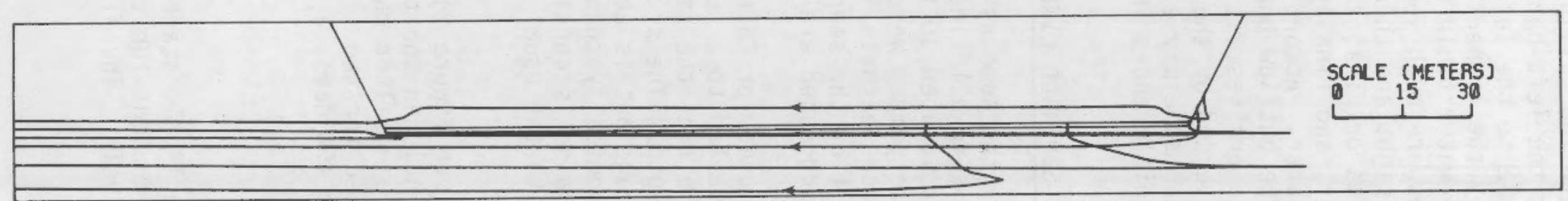

FIGURE 16b. Additional Transport Pathlines for Case 2 with Clay Bottom Liner 
The formation, growth, and diminishing of the mound as leachate seepage enters the water table beneath the tailings pit significantly affects the arrival times of leachate at the left-hand outflow boundary. For those pathlines entering the water table to the left of the mound crest (see Figure 16a), travel times are shortened by the higher mound-induced gradients. However, for those pathlines entering the water table to the right of the mound crest (see Figure 16b), the travel times are much longer. Along these pathlines, the leachate moves first to the right and then gradually slows as the mound peaks, then reverses and retraces its original lateral path through the region where the mound previously had been, and finally arrives at the downstream or lefthand outflow boundary much later. Accordingly, the elapsed time between when the first leachate reaches the outflow boundary and when the later leachate that is detained by the mound arrives, is great because of the extreme difference in the path lengths traversed by the leachate. The differences in time are actually much greater than some may expect because, in general, the time varies as the square of the differences in path lengths.

\section{CASE 3--CLAY BOTTOM AND STUB-SIDEWALL LINERS WITH DRAINS}

This case is essentially the same as Case 2, but with seepage control improved by adding clay stub-sidewall liners to form a saucer-like clay base for the tailings disposal pit located $10 \mathrm{ft}$ above the water table. Four drains that drain into sumps that are pumped were also placed in the tailings above the saucer clay liner to reduce leachate losses to the ground water. Thus, this case used essentially all of the seepage control measures that previous studies and experience have suggested are economically desirable.

The specific dimensions used for Case 3 are shown in Figure 17 . The clay stub-sidewall liners are installed to a height of $6.1 \mathrm{~m}(20 \mathrm{ft})$, which is within the usual rule of thumb that the stubwall height should be 20 to $25 \%$ of the total sluiced tailings depth. The stub liner width is certainly greater than required to control seepage but is about the minimum width and shape that can be realistically and economically constructed. Similarly, the volume of filter material around the drains is considerably greater than actually required but is consistent with the usual construction practices and the size of equipment usually used.

Case 3 used Grid No. 1 (see Figure 2) as the basis for modeling. The soil materials used in the model included the tailings, Sandstone No. 1, clay, the backfill material, and the drain filter material (see Figures 4, 5, 7, 8, and 9). This problem was simulated for the first 450 days with no cover for radon control over the pits. After 450 days, a cover was placed on the pit and the simulation continued.

Fluid Flow Analysis

The flow analysis, using TRUST, started with saturated tailings. The fluid potential and moisture content for the initial condition are shown in Figures $18 \mathrm{a}$ and $19 \mathrm{a}$, respectively. The final conditions are shown in 


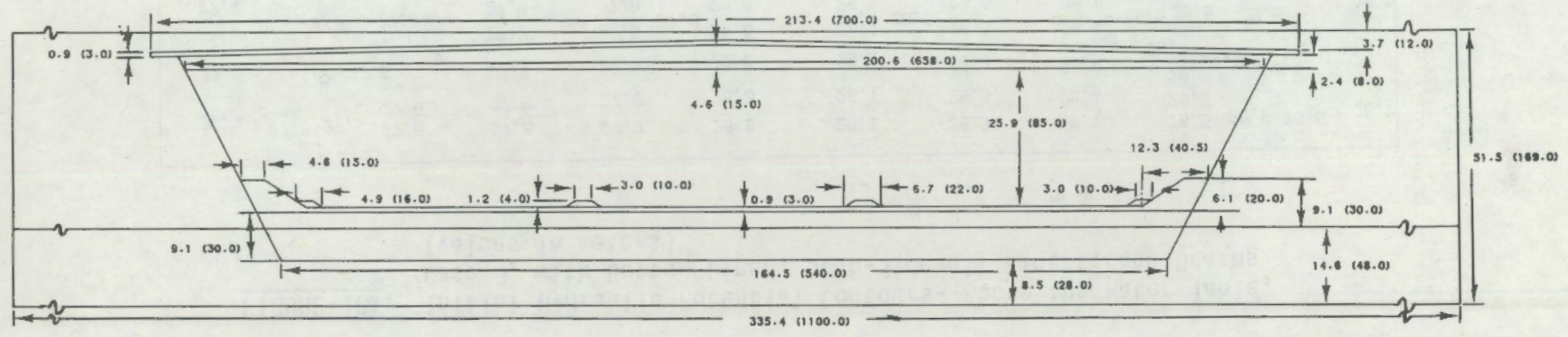

FIGURE 17. Detailed Dimensions in Meters (feet) of Case 3--with Clay Bottom Liner, Stub-Sidewall Liners, and Drains 


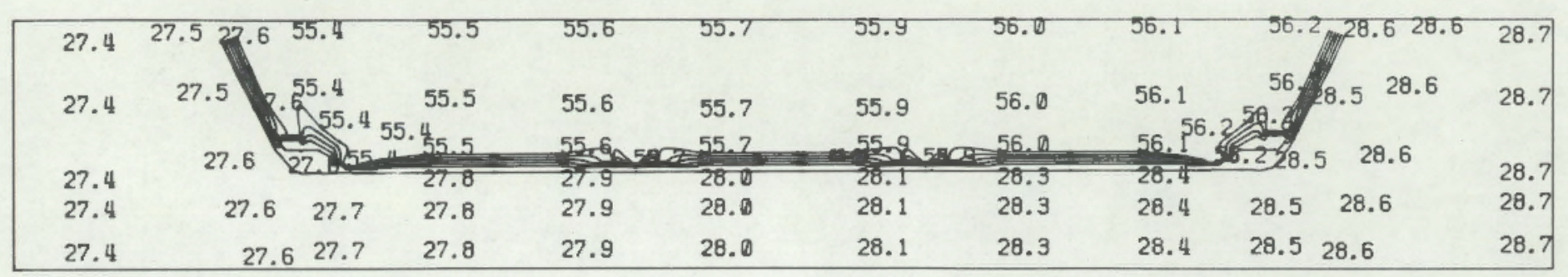

sere comess

FIGURE 18a. Initial Hydraulic Potential Contours--Above the Water Table, Case 3, with Bottom Liner, Stub-Sidewall Liners, and Drains (values in meters)

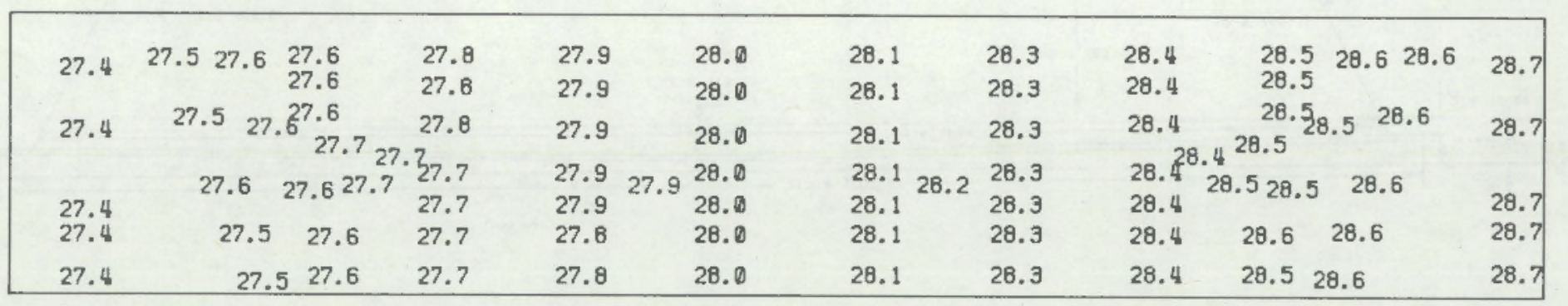

FIGURE 18b. Final Hydraulic Potential Contours--Above the Water Table, Case 3, with Bottom Liner, Stub-Sidewall Liners, and Drains (values in meters 


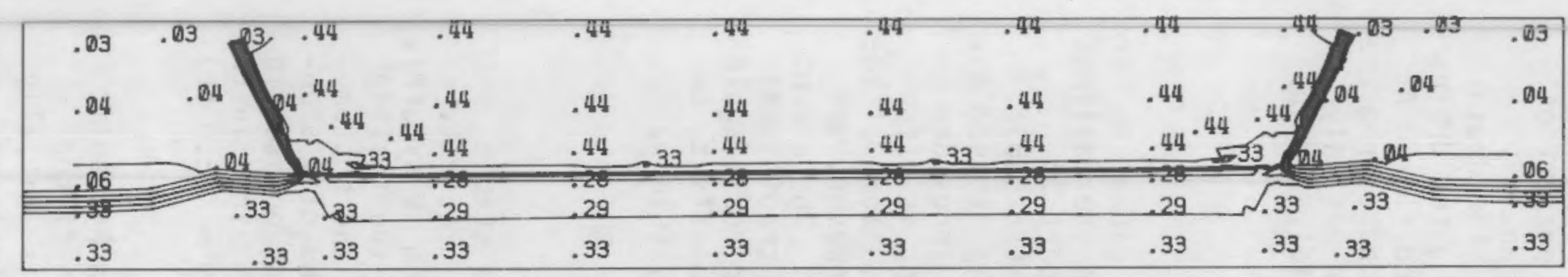

FIGURE 19a. Initial Moisture Content Contours--Above the Water Table, Case 3, with Bottom Liner, Stub-Sidewall Liners, and Drains (values in $\mathrm{m}^{3} / \mathrm{m}^{3}$ )

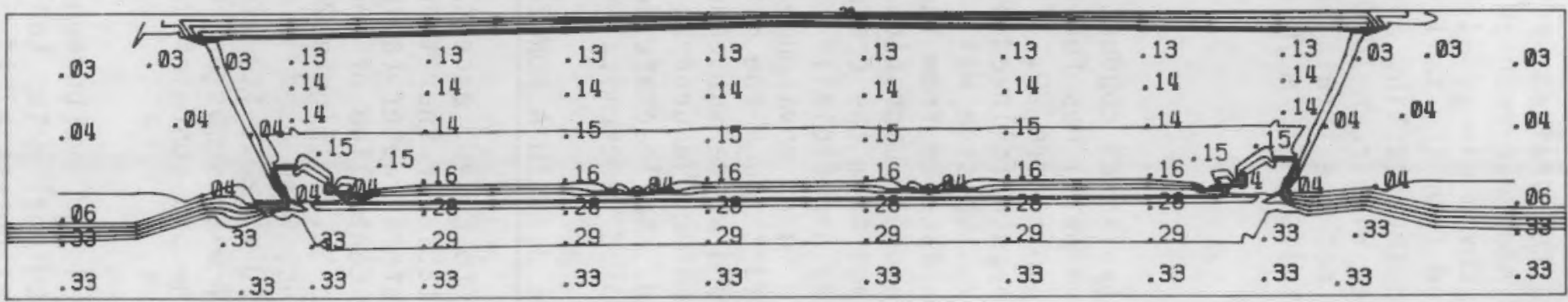

FIGURE 19b. Final Moisture Content Contours--Above the Water Table, Case 3, with Bottom Liner, Stub-Sidewall Liners, and Drains (values in $\mathrm{m}^{3} / \mathrm{m}^{3}$ ) 
Figures $18 \mathrm{~b}$ and $19 \mathrm{~b}$ for the potential and moisture content, respectively. Selected plots at intermediate times are shown in Appendix D.

In general, the tailings drained more rapidly in Case 3 than in the previous two cases because the drainage effluent was pumped. Twenty percent of the drainable leachate had been removed 45 days after drainage began. By 450 days, when the pit cover was added to the simulation, $48.5 \%$ of the drainable leachate had seeped from the tailings. At 2920 days ( 8 years) the drains essentially had stopped intercepting any gf the partially saturated flow. At that time the drains had withdrawn $1090 \mathrm{~m} / \mathrm{m}$ of the drainable leachate from the tailings, which means that the total leachate loss to ground water was only $310 \mathrm{~m} / \mathrm{m}$ out of the total of $1400 \mathrm{~m}^{3} / \mathrm{m}$ of drainable leachate initially in the tailings (for Case 3 ).

Transport Analysis

The transport analysis was conducted in essentially the same manner as for the previous cases. The pathlines for the first leachate to leave the tailings disposal pit are shown in Figure 20. The pathline in the lowest part of Figure 20 indicates the path followed by ground water below the water table. The combination of clay stub-side wall liner and drains effectively stopped any significant seepage of leachate from the pit sidewalls, and hence, provided effective control of leachate migration. Although drainage pumping is effective, the leachate pumped from the drain sumps may be a liability. Some of the leachate can be recycled beneficially through the uranium mill; however, any excess must be disposed in an environmentally satisfactory manner. The amount that can not be recycled through the mill must be discharged to a traditional above-grade tailings pond where subsequent seepage to ground water could again have direct environmental consequences. Once again, for the trade-offs to be appropriately evaluated, the leachate-soil-transport interaction should be analyzed through a coupled geochemical transport analysis.

CASE 4--SIMILAR TO CASE 3, WITH A HORIZONTAL WATER TABLE

Case 4 is similar to Case 3 except that it is located above a static (or horizontal) water table, rather than above one with a lateral gradient. Because there was no lateral water-table gradient, the flow problem is symetrical about the vertical centerline of the pit and only one-half of the tailings pit was modeled by Grid No. 1 (Figure 2). The clay stub-sidewall and bottom liner, along with drains, were used in the Case 4 simulations. The clay stubsidewall liners are $6.10 \mathrm{~m}(20.0 \mathrm{ft})$ high as in Case 3 . Two drains encased in coarser filter material with sumps are placed over the clay bottom liner in the half pit simulated. The pit contains tailings to a depth of $25.09 \mathrm{~m}(85.0 \mathrm{ft})$ as in the previous cases.

The Sandstone No. 1 and overburden materials are initially in hydraulic equilibrium with the regional water table. The tailings and drain filter material have an initial potential of $56.1 \mathrm{~m}$ (184 ft). All clay is initially saturated; the potential at each clay node was set equal to its elevation (pressure head $=0.0 \mathrm{~m}$ ). 


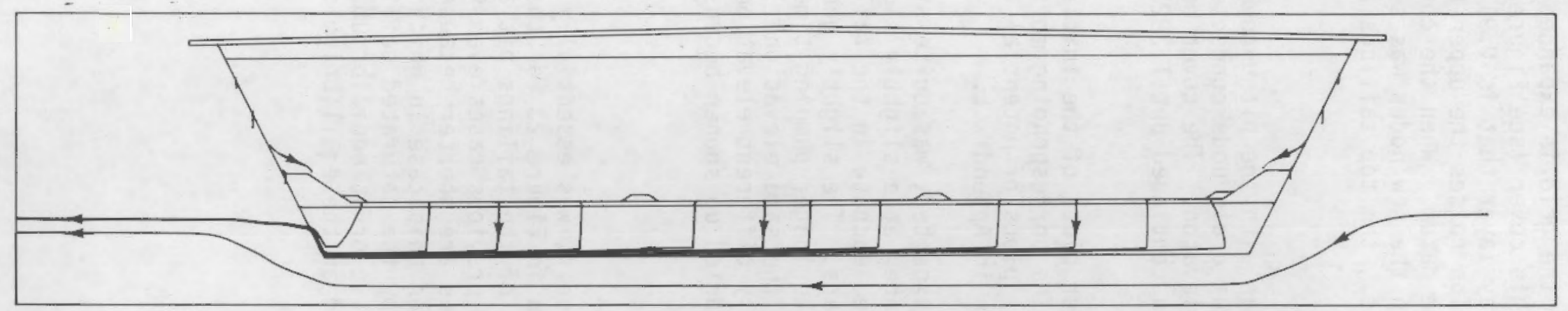

FIGURE 20. Leachate Pathlines--Above the Water Table, Case 3, with Bottom Liner, Stub-Sidewall Liners, and Drains 
After a period of simulation, the grid is expanded above the pit to account for a surface covering. This cover (see Figure lb) consists of a layer of overburden, a sloping (2.0\%) clay layer that is $0.91 \mathrm{~m}(3.0 \mathrm{ft})$ thick, and additional overburden. This addition raises the upper boundary to ground level, $64.31 \mathrm{~m}(211.0 \mathrm{ft})$ above the datum. When the cover was added during simulation, the initial pressure in the new nodes was set to the pressure head of the nodes immediately below (i.e., the top tailings nodes).

\section{Fluid Flow Analysis}

The analysis of this case began with the pit uncovered and the drains open. An open drain consists of the drain node connected to an external node with potential held at the nodal elevaton. The cover nodes were added after 478 days of simulation. Simulation continued until 3923 days (10.75 years), at which time the drains were closed.

Figures $21 \mathrm{a}$ and $21 \mathrm{~b}$ are contour plots of the initial and final potential heads for the Case 4 simulation. The corresponding moisture contours are shown in Figures $22 \mathrm{a}$ and $22 \mathrm{~b}$. Additional plots of potential head and the moisture content at selected times are shown in Appendix $E$.

The drainage from Case 4, as expected, was quite similar to Case 3, though the drains did continue running longer at a slightly slower rate. A total of $1106 \mathrm{~m} / \mathrm{m}$ or $79.5 \%$ of the drainable leachate in the tailings was pumped from the drains over the first 10.75 years. The slightly greater amount of leachate intercepted (about 1\% more), and the longer pumping time, for Case 4 is a result of the drains all placed at the same elevation. By contrast, in Case 3 the four drains are each at slightly different elevations due to the lateral gradient, and the upstream drains dried up sooner because of that slightly higher elevation.

Transport Analysis

The transport analysis for Case 4, was essentially the same as the previous cases. The results are shown in Figure 23 for the paths of fluid particles originating around the edge of the tailings pit at zero time. The pathlines are shorter than for the previous cases even though the leachate drainage took longer. The pathlines are shorter because there is no persistent regional ground-water gradient. For this case in which the water table is horizontal, once the head induced by the saturated tailings in the pit is dissipated, the flow system is static or at equilibrium; hence, the pathlines gradually slow down and finally end at the equilibrium static condition. 


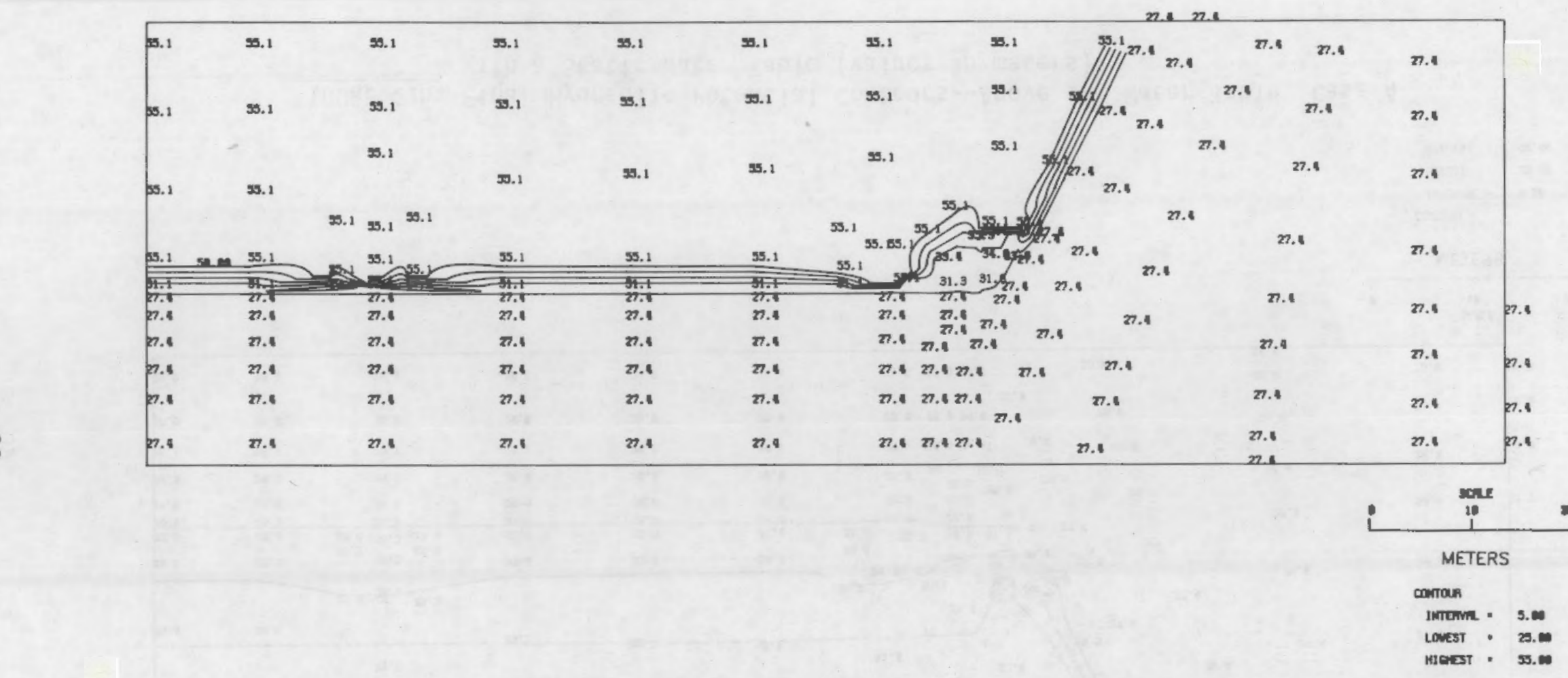

FIGURE 2la. Initial Hydraulic Potential Contours--Above the Water Table, Case 4, with a Static Water Table (values in meters) 


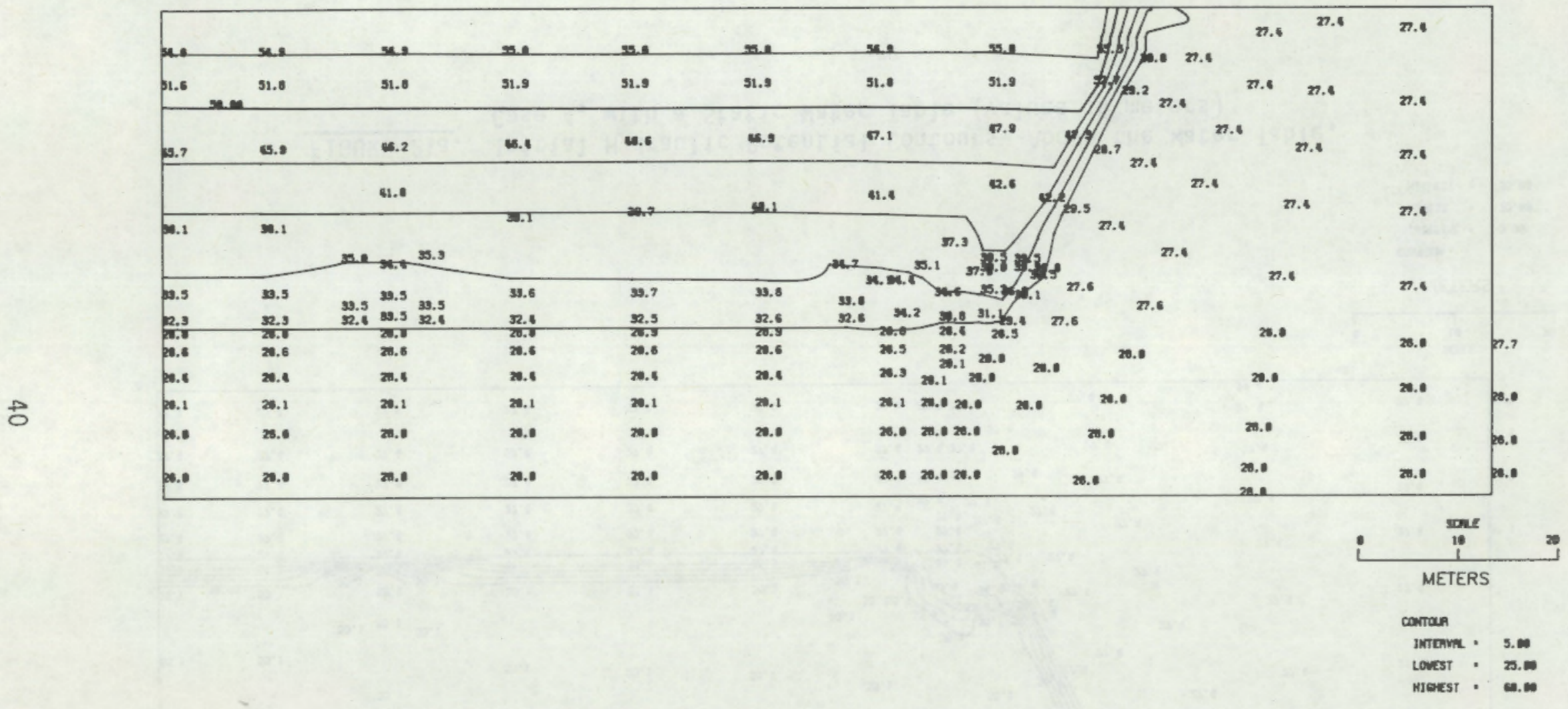

FIGURE 21b. Final Hydraulic Potential Contours--Above the Water Table, Case 4 with a Static Water Table (values in meters) 


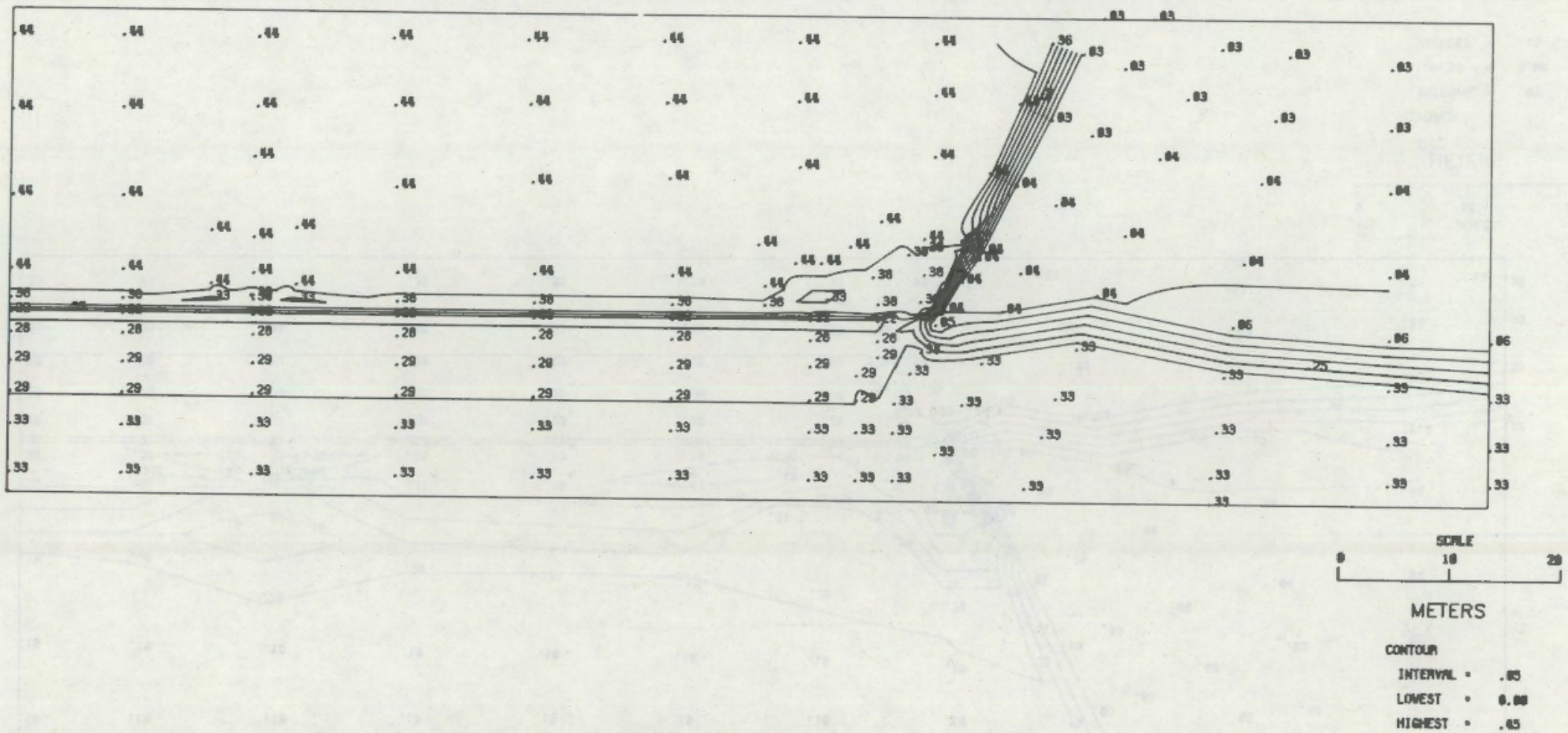

FIGURE 22a. Initial Moisture Content Contours--Above the Wâter Table, Case 4, with a Static Water Table (values in $\mathrm{m}^{3} / \mathrm{m}^{3}$ ) 


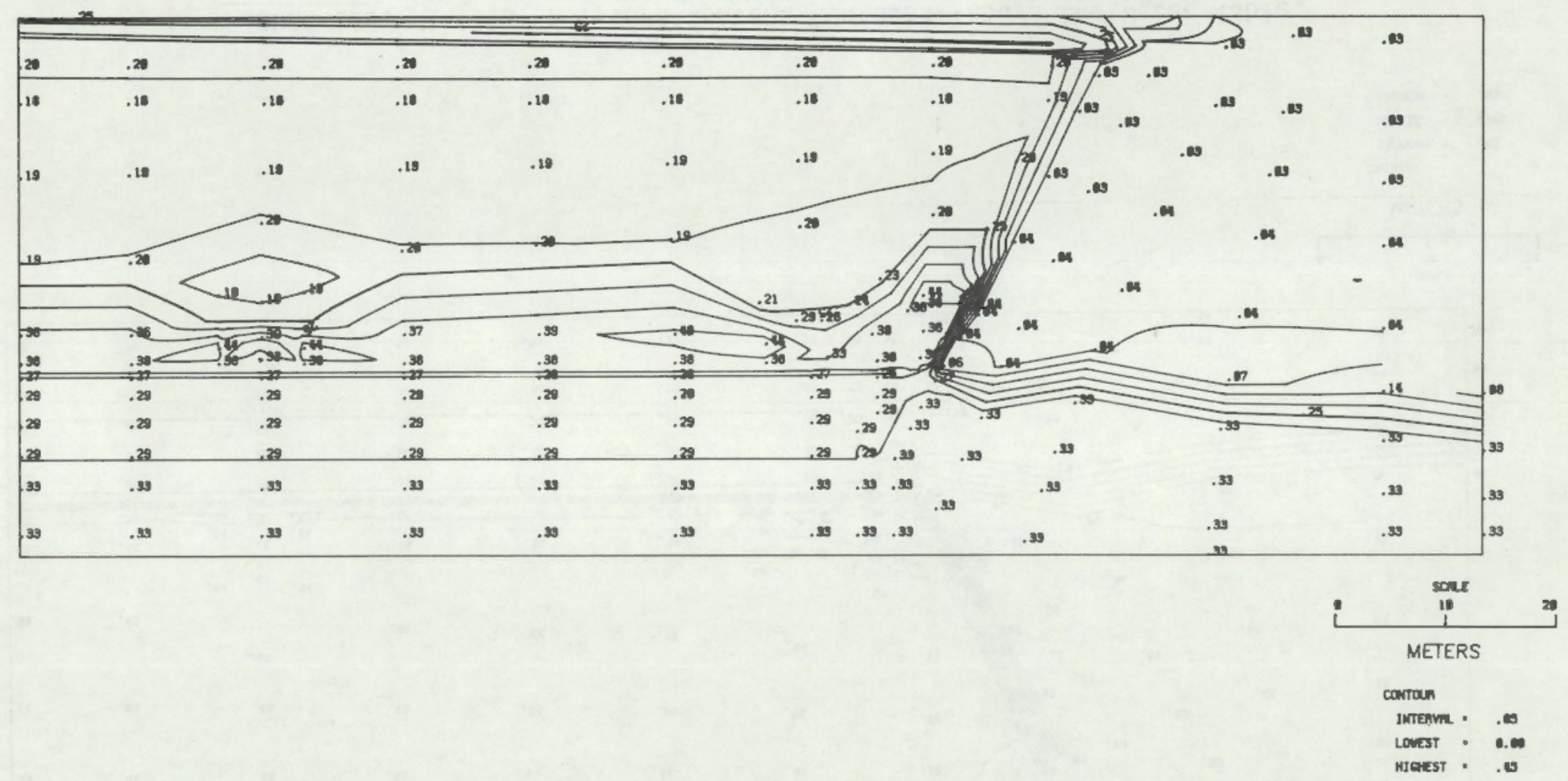

FIGURE 22b. Final Moisture Content Contours--Above the Water Table, Case 4 with a Static Water Table (values in $\mathrm{m}^{3} / \mathrm{m}^{3}$ ) 


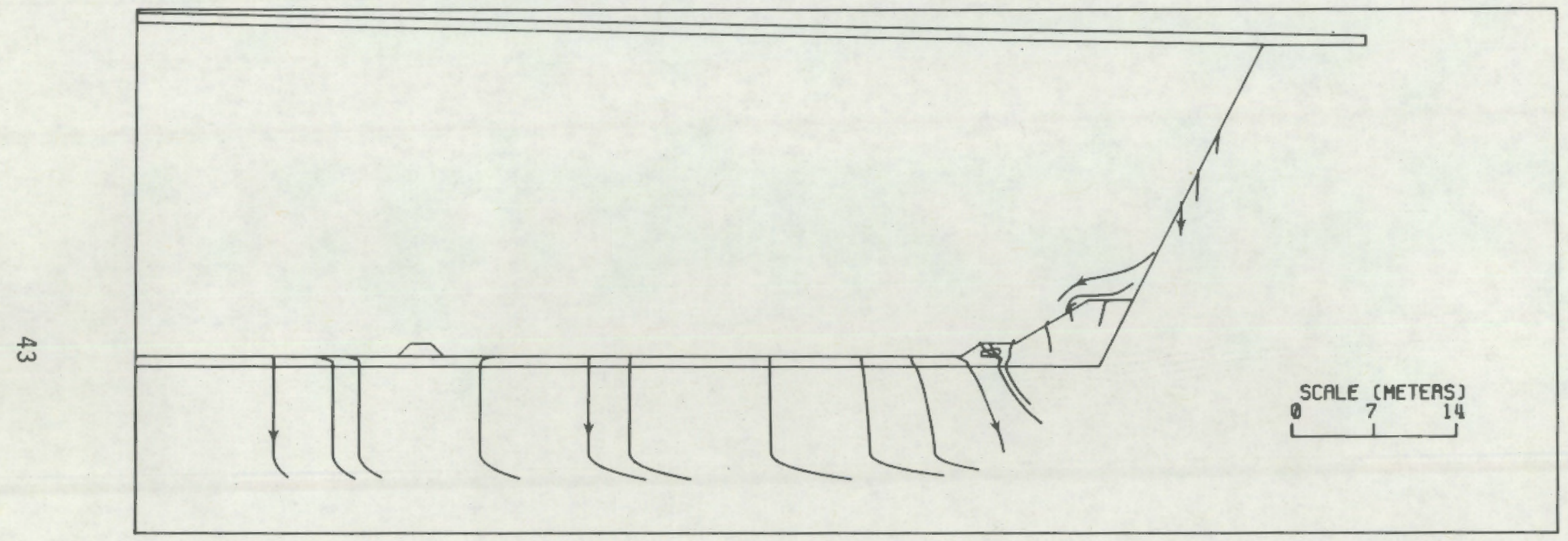

FIgURE 23. Transport Pathline--Above the Water Table, Case 4 with a Static Water Table 



\section{DISPOSAL CASES BELOW THE WATER TABLE}

The three cases for disposal below the water table in this section are exact counterparts of the first three cases for disposal above the water table discussed in the previous section. The only difference is that the following cases are below the water table so ground-water will flow through the tailings laterally. We did not analyze a case for disposal below the water table similar to Case 4 because such a case would be unrealistic.

CASE 5--BELOW THE WATER TABLE REFERENCE CASE

The simulations for this case were the same as those for Case 1, except the water table was raised $27.4 \mathrm{~m}(90 \mathrm{ft})$. Specifically, the water table was raised to $54.86 \mathrm{~m}$ (180 ft) above the level datum at the left boundary and $56.54 \mathrm{~m}$ (185.5 ft) at the right boundary, leaving only $1.83 \mathrm{~m}(6 \mathrm{ft})$ of sandstone above the water table to the uncovered land surface. As in Case 1, this case uses Grid No. 2 (Figure 3 ) with the Sandstone No. 2 and tailings

(Figures 4 and 6 ).

\section{Fluid Flow Analysis}

We analyzed the flow with the TRUST code. Figures 24a and 24b show the initial and final fluid potential distributions. Figures $25 \mathrm{a}$ and $25 \mathrm{~b}$ show the moisture contours for the initial and final drained conditions. Additional plots of the potential head and moisture content of the tailings at selected times are given in Appendix F.

Simulation of this case was simple and relatively fast, because the problem does not involve resaturation of the region between the water table and the bottom of the tailings. The tailings leachate is primarily displaced laterally by ground water seeping through the saturated tailings. Partially saturated drainage from the tailings above the water table was also minimal. These small volumes of tailings that are partially saturated at the final steady-state conditions (i.e., dynamic steady-state because of the regional ground-water flow) are only a short distance above the final water-table position, and thus, have little effect.

\section{Fluid Transport Analysis}

We analyzed the fluid transport with the MLTRAN subprograms as previously described. Fluid particles originating around the edge of the tailings at zero time were followed along their respective numbered pathlines, as seen in Figure 26. The summary of the leachate arrival data at the left end of the vertical cross-section for the twenty-three pathlines shown in Figure 26 is given in Table 2. The first and twenty-third pathlines in Table 2 and in Figure 26 do not reach the left-hand boundary, so their arrival times and path lengths are not shown in the table. These two pathlines end along the upper boundary, a result of a numerical constraint in the generating capability for 


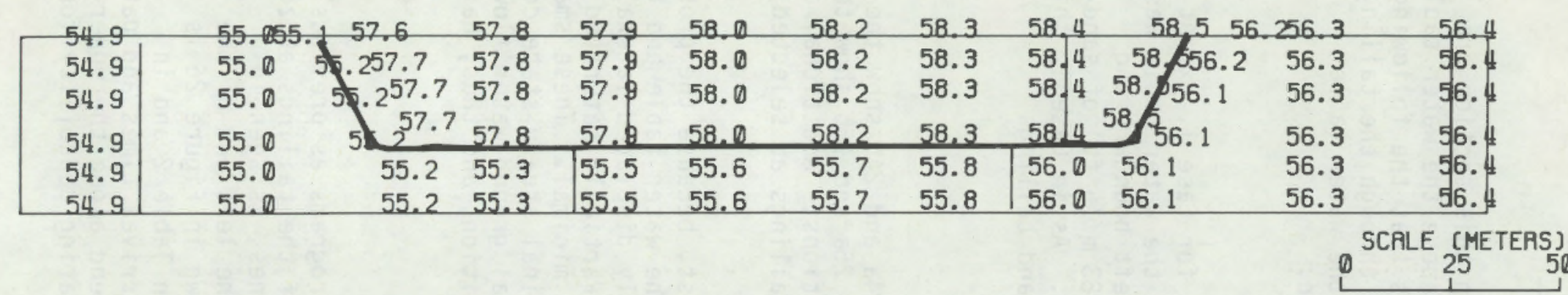

CONTOUR

INTERVAL $=.50$

LOWEST $=\dot{54} .50$

HIGHEST $=59.00$

FIGURE 24a. Initial Hydraulic Potential Contours--Below the Water Table, Case 5 (values in meters)

\begin{tabular}{|c|c|c|c|c|c|c|c|c|c|c|c|}
\hline-54.9 & -55.15 & 255.3 & 55.4 & 55.5 & 55.6 & 55.7 & 55.8 & 55.9 & \multicolumn{2}{|c|}{56.956 .156 .2} & 56.4 \\
\hline 54.9 & 55.1 & 55.255 .3 & 55.4 & 55.5 & 55.6 & 55.7 & 55.8 & 55.9 & 56.056 .1 & 56.2 & 56.4 \\
\hline 54.9 & 55.1 & $55.3^{55.3}$ & 55.4 & 55.5 & 55.6 & 55.7 & 55.8 & 55.8 & $56.0_{56.0}$ & 56.2 & 56.4 \\
\hline 54.9 & 55.1 & $55.3^{55.3}$ & 55.4 & 55.5 & 55.6 & 55.7 & 55.8 & $55<9$ & 56.85 .0 & 56.2 & 56.4 \\
\hline 54.9 & 55.1 & 55.3 & 55.4 & 55.5 & 55.6 & 55.7 & 55.8 & 55.8 & 56.0 & 56.2 & 56.4 \\
\hline 54.9 & 55.1 & 55.3 & 55.4 & 55.5 & 55.6 & 55.7 & 55.8 & 55.6 & 56.0 & 56.2 & 56.4 \\
\hline
\end{tabular}

CONTOUR

INTERVAL $=.50$

LOWEST $=54.50$

HIGHEST $=59.00$

FIGURE 24b. Final Hydraulic Potential Contours--Below the Water Table, Case 5 (values in meters) 


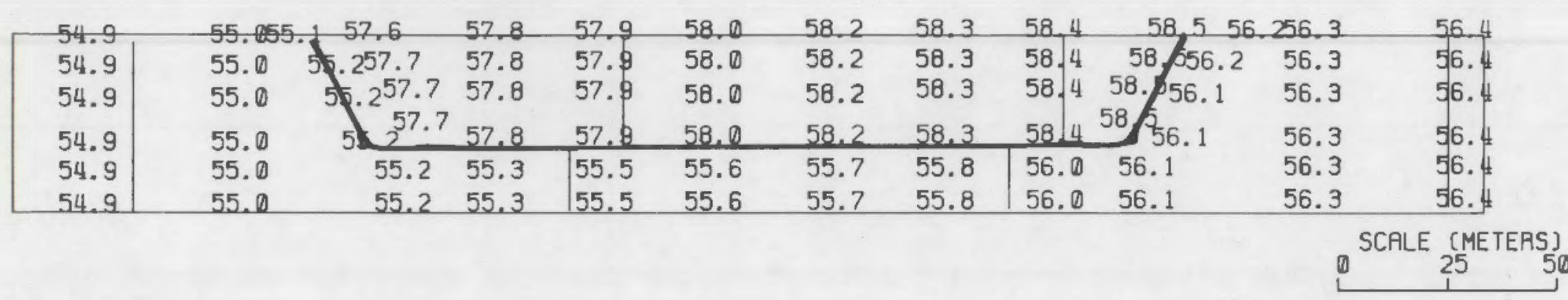

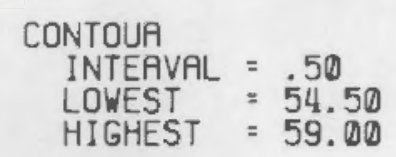

FIGURE 25a. Initial Moisture Content Contours--Below the Water Table, Case 5 (values in $\mathrm{m}^{3} / \mathrm{m}^{3}$ )

\begin{tabular}{|c|c|c|c|c|c|c|c|c|c|c|c|}
\hline 54.9 & 55.15 & .255 .3 & 55.4 & 55.5 & 55.6 & 55.7 & 55.8 & 55,9 & \multicolumn{2}{|c|}{$56.0 \quad 56.256 .2$} & 56.4 \\
\hline $54 . \$$ & 55.1 & 55.255 .3 & 55.4 & 55.5 & 55.6 & 55.7 & 55.8 & 55.9 & 56.056 .1 & 56.2 & 55. 4 \\
\hline 54.9 & 55.1 & $55.3^{55.3}$ & 55.4 & 55.5 & 55.6 & 55.7 & 55.8 & 55.9 & 56.056 .1 & 56.2 & 55.4 \\
\hline 54.9 & 55.1 & $55.3^{55.3}$ & 55.4 & 55.5 & 55.6 & 55.7 & 55.8 & 55. & 56.856 .0 & 56.2 & 56.4 \\
\hline 54.9 & 55.1 & 55.3 & 55.4 & 55.5 & 55.6 & 55.7 & 55.8 & 55.9 & 56.0 & 56.2 & 56.4 \\
\hline 54.9 & 55.1 & 55.3 & 55.4 & 55.5 & 55.6 & 55.7 & 55.8 & 55.9 & 56.0 & 56.2 & 56.4 \\
\hline & & & & & & & & & & $0^{\text {SCA }}$ & 25 \\
\hline & & & & & & & & & & $\begin{array}{l}\text { ONTOUA } \\
\text { INTEAVAL } \\
\text { LOWEST } \\
\text { HIGHEST }\end{array}$ & $\begin{array}{l}50 \\
54.50 \\
59.00\end{array}$ \\
\hline
\end{tabular}

FIGURE 25b. Final Moisture Content Contours--Below the Water Table, Case 5 (values in $\mathrm{m}^{3} / \mathrm{m}^{3}$ ) 


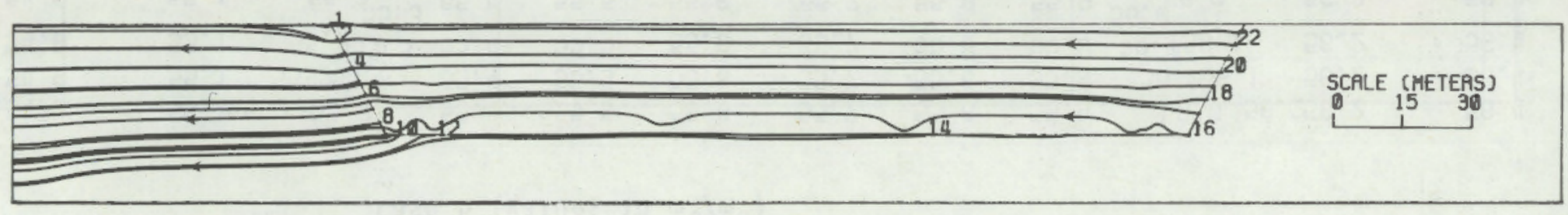

FIGURE 26. Pathlines of Particles Starting at Edge of Pit at Time $(t=0)$ for Below the Water Table, Case 5 


\section{TABLE 2. Pathline Arrival Data at Outflow Boundary for Case 5}

\begin{tabular}{|c|c|c|c|c|c|c|}
\hline \multirow{2}{*}{$\begin{array}{l}\text { Pathline } \\
\text { Number } \\
\text { (Fig.26) }\end{array}$} & \multirow{2}{*}{$\begin{array}{l}\text { Departure } \\
\text { Time } \\
\text { (days) } \\
\end{array}$} & \multicolumn{2}{|c|}{$\begin{array}{l}\text { Starting Location } \\
\text { Along Pit Edge }\end{array}$} & \multirow{2}{*}{$\begin{array}{l}\text { Outflow } \\
\text { Elevation, } S \text {, } \\
\text { Along Outflow } \\
\text { Boundary (meters) }\end{array}$} & \multicolumn{2}{|c|}{$\begin{array}{l}\text { Arrival } \\
\text { Time at } \\
\text { Boundary }\end{array}$} \\
\hline & & (meters) & (meters) & & (days) -- & (years) \\
\hline 1 & 0.0 & 68.77 & 54.86 & - & - & \\
\hline 2 & 0.0 & 70.31 & 51.82 & 53.13 & $4.6997\left(10^{4}\right)$ & $(128.76)$ \\
\hline 3 & 0.0 & 71.79 & 48.88 & 49.20 & $4.5405\left(10^{4}\right)$ & $(124.40)$ \\
\hline 4 & 0.0 & 73.40 & 45.72 & 44.64 & $5.3768\left(10^{4}\right)$ & (147.31) \\
\hline 5 & 0.0 & 74.94 & 42.67 & 40.26 & $5.4601\left(10^{4}\right)$ & (149.59) \\
\hline 6 & 0.0 & 76.48 & 39.62 & 36.19 & $5.5608\left(10^{4}\right)$ & $(152.35)$ \\
\hline 7 & 0.0 & 78.03 & 36.58 & 32.21 & $5.7707\left(10^{4}\right)$ & $(158.10)$ \\
\hline 8 & 0.0 & 79.57 & 33.52 & 28.23 & $6.0540\left(10^{4}\right)$ & $(165.86)$ \\
\hline 9 & 0.0 & 80.69 & 30.88 & 24.93 & $6.2285\left(10^{4}\right)$ & $(170.64)$ \\
\hline 10 & 0.0 & 82.30 & 30.90 & 24.26 & $6.3353\left(10^{4}\right)$ & $(173.57)$ \\
\hline 11 & 0.0 & 83.82 & 30.91 & 22.59 & $6.5228\left(10^{4}\right)$ & (178.71) \\
\hline 12 & 0.0 & 91.44 & 30.94 & 19.87 & $7.6533\left(10^{4}\right)$ & $(209.68)$ \\
\hline 13 & 0.0 & 167.64 & 31.32 & 19.50 & $1.4350\left(10^{5}\right)$ & (393.15) \\
\hline 14 & 0.0 & 198.12 & 31.40 & 19.49 & $1.7886\left(10^{5}\right)$ & $(490.03)$ \\
\hline 15 & 0.0 & 228.60 & 31.69 & 19.51 & $1.8149\left(10^{5}\right)$ & $(497.23)$ \\
\hline $16^{(a)}$ & 0.0 & 254.86 & 31.75 & 27.46 & $2.0\left(10^{5}\right)$ & $(548)$ \\
\hline 17 & 0.0 & 257.01 & 36.58 & 34.53 & $1.8600\left(10^{5}\right)$ & $(507.00)$ \\
\hline 18 & 0.0 & 258.51 & 39.62 & 36.38 & $1.8383\left(10^{5}\right)$ & $(503.64)$ \\
\hline 19 & 0.0 & 260.02 & 42.67 & 39.83 & $1.8100\left(10^{5}\right)$ & $(495.89)$ \\
\hline 20 & 0.0 & 261.53 & 45.72 & 44.87 & $1.7765\left(10^{5}\right)$ & $(486.71)$ \\
\hline 21 & 0.0 & 263.04 & 48.77 & 49.45 & $1.7556\left(10^{5}\right)$ & $(480.99)$ \\
\hline 22 & 0.0 & 264.54 & 51.82 & 54.42 & $2.3402\left(10^{5}\right)$ & (641.15) \\
\hline 23 & 0.0 & 266.05 & 54.86 & - & - & -- \\
\hline
\end{tabular}

(a) Pathline 16 (Figure 26) contains inaccuracies. See text for discussion. 
the finite-element pathline near an outer boundary. That is, any time a pathline passes outside of the outer node points, it is automatically terminated, removing the need to extrapolate the velocity outside of the node points of the flow system.

Pathline 16 in Figure 26 shows evidence of inaccuracies; mild effects of this inaccuracy may extend into Pathline 17. These irregularities are caused by the numerical difficulties in generating pathlines through the very irregular nodal grid (see Figure 3 ) that represents the drains and clay stub-sidewall liners used when simulating the other more-involved cases. The arrival time for Pathline 16 (given in Table 2) is not used in the subsequent analysis. Experience suggests that the observed irregular pathlines are the lesser of two evils. A smaller nodel grid with more interconnections is required if we are to realistically represent converging flow toward the drains in the TRUST flow simulation when drains are used. Experience also has shown that any numerical pathline generation difficulties are readily observed if they occur, as in Figure 26. The consistency of the other pathlines, in terms of both the shape of the pathline in the figure and in the arrival times at the left boundary, indicate the accuracy of the other pathlines generated.

Tailing Leaching by Ground Water

Experimental work on tailings leaching has been completed in the laboratory and can be used with the fluid transport analysis of the last section to realistically estimate the concentration of leachate constituents in the ground-water seeping through the tailings. The approach developed for the analysis is illustrated here with the sulfate as the example constituent.

For Reference Case 1 (above the water table) the leachate drainage from the disposal pit was at a constant sulfate concentration of $14,000 \mathrm{mg} / \ell$. Knowing the amount of drainable fluid in the pit allows us to determine that $2.08 \times 10^{7} \mathrm{~g} / \mathrm{m}$ of sulfate per unit pit length enters the ground water.

The amount of sulfate leaving the pit for Case 5 , below the water table is more difficult to calculate. The concentrations change in time and space as fresh ground water flows through the tailings, leaching ever-decreasing quantities of sulfate out of the pit. The analysis is based on the measured leachate concentrations obtained from laboratory column experiments. Figure 27 plots the sulfate leaching results from two column experiments run on Highland Mill tailings. The curve in the figure was used as the representative curve through the measured data points. The initial sulfate concentration in the tailings liquor was $14,000 \mathrm{mg} / \ell$ of sulfate and was constant for the first column pore volume of fluid. During the first 3 column volumes, the sulfate reduced significantly to $6000 \mathrm{mg} / \ell$, with further reduction to $1800 \mathrm{mg} / \mathrm{\ell}$ at $10 \mathrm{column}$ volumes of ground water passing through the tailings. By 70 column volumes the leachate sulfate concentration had declined to $185 \mathrm{mg} / \mathrm{\ell}$, or very nearly returned to the background ground-water sulfate concentration. These measured leaching data, as in Figure 27, coupled with the pathline boundary arrival data in Table 2, are the bases for incorporating the tailings leaching chemical results into the transport analysis. 


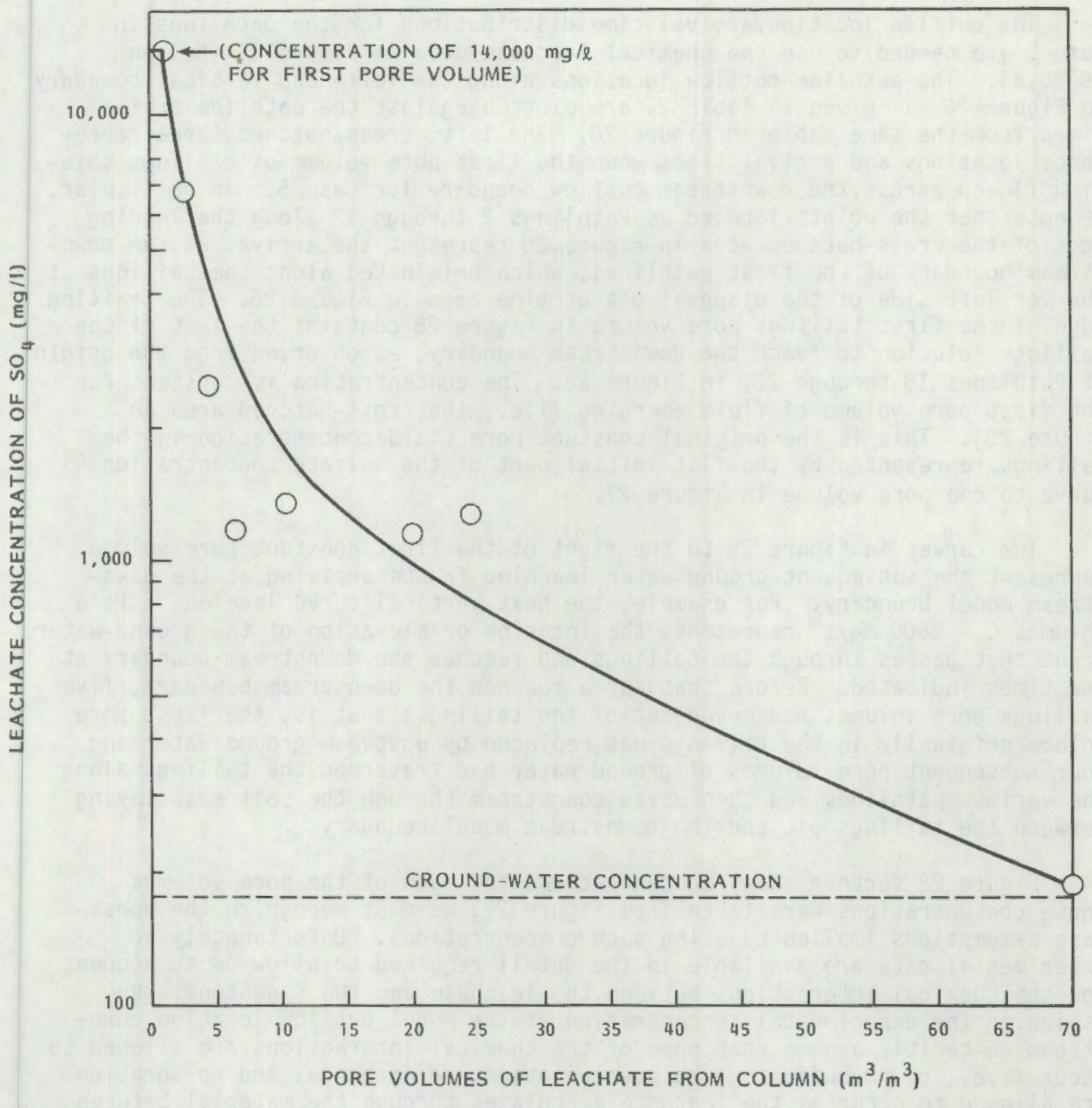

FIGURE 27. Effluent Sulfate Concentration from Laboratory Tailings Columns Leached with Ground Water (from Gee et al. 1980a, 1981) 
The outflow location/arrival time distributions for the pathlines in Case 5 are needed to use the chemical leachate data in Figure 27. (Nelson 1978b,d). The pathline outflow locations along the left-hand vertical boundary in Figure 26, as given in Table 2, are plotted against the pathline arrival times from the same table in Figure 28. The left, cross-hatched, area represents locations and arrival times when the first pore volume of tailings solution flowed across the downstream outflow boundary for Case 5. In particular, we note that the points labeled as Pathlines 2 through 12 along the leading edge of the cross-hatched area in Figure 28 represent the arrival at the downstream boundary of the first pathlines, which originated along the tailings at the far left side of the disposal pit at time zero in Figure 26. The trailing edge of the first tailings pore volume in Figure 28 contains the last of the tailings solution to reach the downstream boundary, as observed from the origin of Pathlines 15 through 22, in Figure 26. The concentration is constant for the first pore volume of fluid emerging (i.e., the cross-hatched area in Figure 28). This is the original constant pore fluid concentration in the tailings, represented by the flat initial part of the sulfate concentration curve to one pore volume in Figure 27.

The curves in Figure 28 to the right of the first constant pore volume represent the subsequent ground-water leaching fronts arriving at the downstream model boundary. For example, the next vertical curve labeled "5 Pore Volumes $C=3600 \mathrm{mg} / \ell^{\prime \prime}$ represents the location or elevation of the ground-water front that passes through the tailings and reaches the downstream boundary at the times indicated. Before that curve reached the downstream boundary, five tailings pore volumes had moved out of the tailings; that is, the first pore volume originally in the tailings was replaced by upstream ground water and four subsequent pore volumes of ground water had traversed the tailings along the various pathlines and then moved downstream through the soil mass laying between the tailings pit and the downstream model boundary.

Figure 28 further shows concentrations for each of the pore volumes. Those concentrations were taken from Figure 27; we must recognize the worstcase assumptions implied by using such concentrations. Unfortunately no experimental data are available in the detail required to allow us to account for the chemical interactions between the leachate and the sandstone. By assigning the experimental concentration at the model outflow location downstream we tacitly assume that none of the chemical interactions are allowed to occur (i.e., no pH buffering, no precipitation, no exchange, and no sorption are allowed to occur as the leachate percolates through the material between the tailings and the downstream end of the model). This represents a very severe, worst-case assumption that may lead to severe calculated detrimental consequences.

Only the arrival location/outflow quantity distribution is then needed to evaluate the worst-case sulfate migration from Case 5 (Nelson 1978a,b,c,d). These results are available from the TRUST flow analysis and are shown in Figure 29. The unit outflow rate of leachate is determined by the volume flow rate in meters per day per meter of height, $S$, per unit meter of tailings pit 


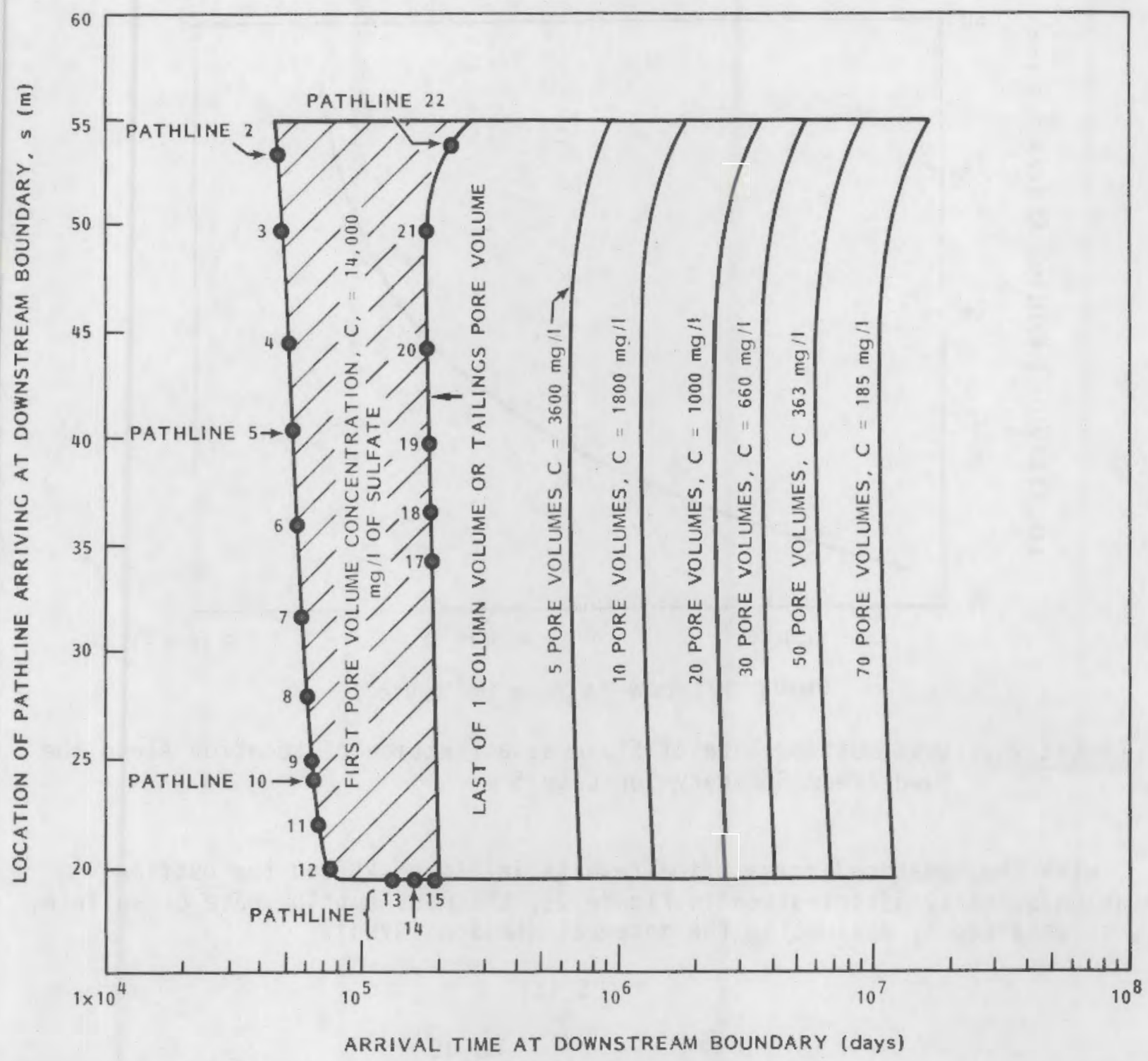

FIGURE 28. Location/Arrival Time Results for Pathlines at Downstream
Boundary of Case 5

length, which results in a unit outflow rate of $\mathrm{m} /$ day. Figure 29 has only one curve because the pathline arrival times of 40,000 days and greater from Figure 28 are much greater than the 20,000 days required for the flow system to essentially reach a steady flow condition. Accordingly, only one curve is involved for the steady flow conditions. 


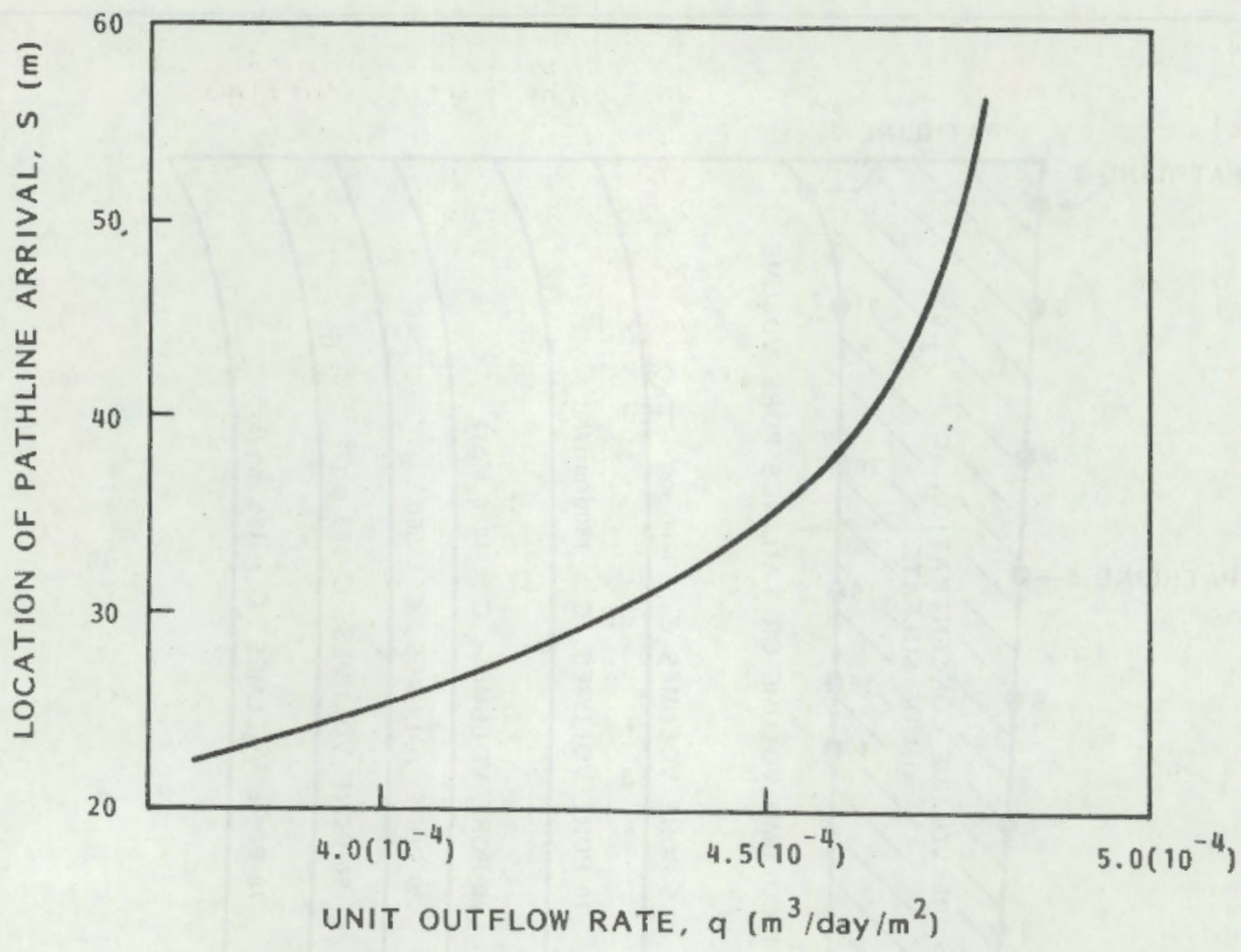

FIGURE 29. Unit Outflow Rate of Fluid as a Function of Location Along the Downstream Boundary for Case 5

With the location/arrival time results in Figure 28 and the outflow location/quantity distribution in Figure 29 , the mass outflow rate of sulfate, $W_{s}$, is obtained by evaluating the integral (Nelson 1978d):

where

$$
w_{s}(t)=\int_{S_{1}(t)}^{S_{2}(t)} c q d S
$$

$C$ is the concentration (sulfate in this case), which is a function of $S$

$q$ is the unit fluid outflow rate, which is a function of $S$

$S_{1}(t)$ is the minimum or lower boundary outflow location from Figure 28 at time, $\mathrm{t}$

$S_{2}(t)$ is the upper boundary outflow location from Figure 28 at time, $t$.

We formed the product of the concentration from Figure 28 and the unit fluid flux from Figure 29 by using the common linking variable of the outflow location, $S$, which enabled us to evaluate the integral mass outflow rate $W_{S}$ at time, $t$, using the above equation. By sequentially evaluating this equation for other times, we obtained the mass outflow rate of sulfate crossing the downstream boundary as a function of time (see Figure 30). The sulfate outflow 
rate as a function of time in the figure is the worst case or maximum rate of sulfate transport away from the buried tailings disposed in the pit below the water table. Integration of the area under the sulfate outflow rate curve (Figure 30) produces the mass of sulfate that has left the pit. This case for below the water table (Case 5 ) results in $1.51 \times 10^{8} \mathrm{~g} / \mathrm{m}$ sulfate entering the ground-water system. This represents 7.26 times the sulfate from Case 1 above the water table.

We should remember the severity of,the worst-case results in Figure 30 and hence the factor of 7.26. The results of complete leaching of sulfate from the tailings by ground water, as obtained from the scaled-up laboratory leaching experiments, are included in Figure 30. However, laboratory column experiments of the leachate $\mathrm{pH}$ being buffered and of the related chemical interaction with the sandstone material were not available and so were ignored; thus, the chemical and exchange interactions were not taken into account. Accordingly, we considered none of the sulfate reduction that would occur during leachate neutralization and so forth during migration through the sandstone in the analysis leading to the results in Figure 30 . These worst-case results give much higher sulfate flow rates away from the tailings pit than would actually occur in view of the findings of Gee 1980a.

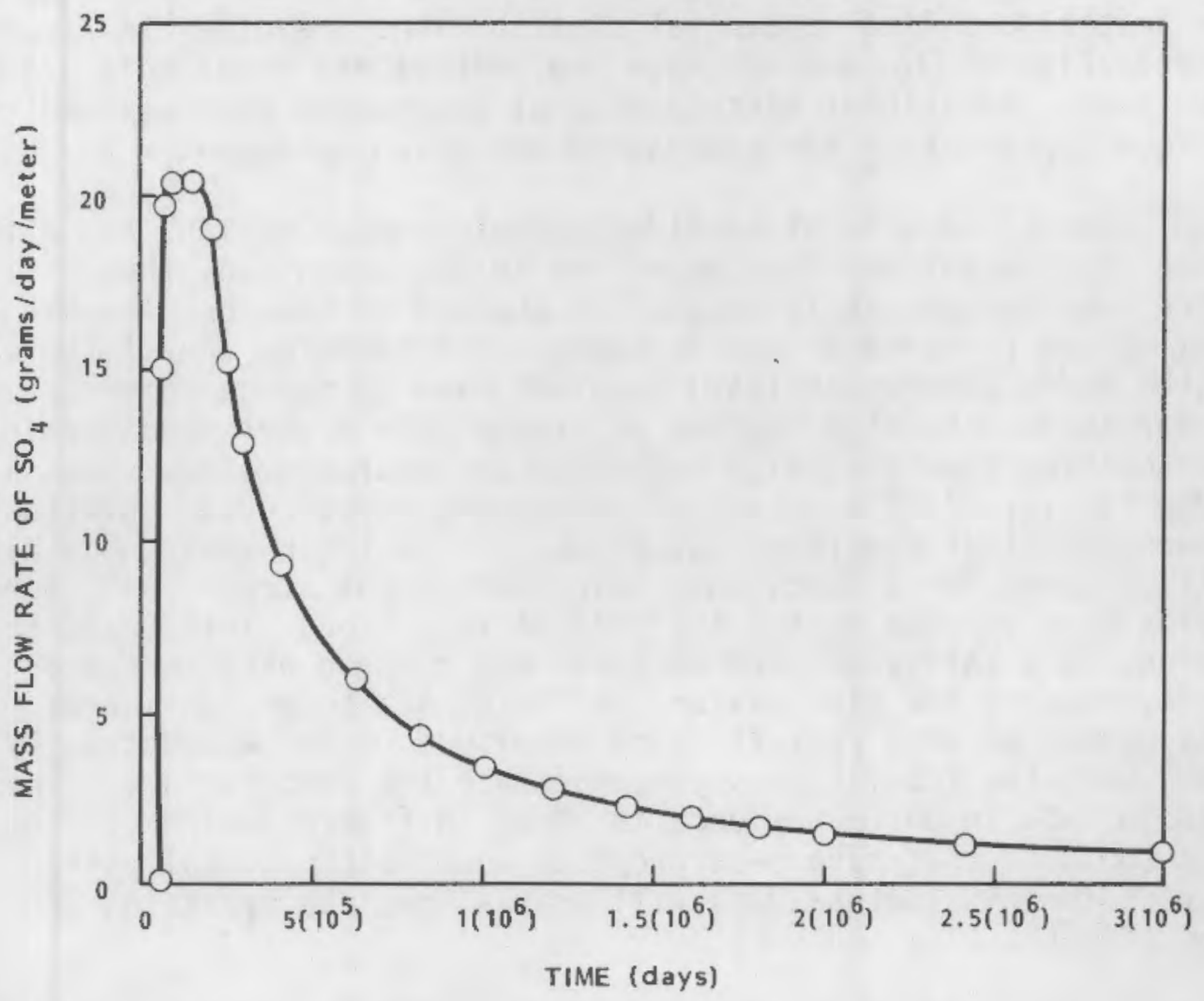

FIGURE 30. Sulfate Flow Rate in Ground Water Away from the Belowthe-Water-Table Tailings Disposal Pit in Case 5 
This case is similar to Case 5 described above, with the addition of a clay bottom liner. It is also the same as Case 2, except that the tailings are disposed in ground water below the water table rather than above the saturated zone. A $0.91 \mathrm{~m}(3 \mathrm{ft})$ thick clay bottom liner was used for Case 6 as in Case 2.

Flow Analysis

The flow analysis was the same as for Case 2, except that the water table was raised $27.43 \mathrm{~m}(90 \mathrm{ft})$. Specifically, Grid No. 2 was used, with the water table fixed at the left grid boundary at $54.86 \mathrm{~m}(180.0 \mathrm{ft})$ and at the right grid boundary at a value of $56.54 \mathrm{~m}(185.5 \mathrm{ft})$. This corresponds to a regional gradient of 0.005 across the $335.28 \mathrm{~m}$ (1100 ft) grid. The substrate, or parent material, used is again the Sandstone No. 2. The material properties of the uranium mill tailings, Sandstone No. 2, and clay are described in the analysis techniques section (see Figures 4, 6, and 7).

Once again, because the case is primarily saturated and does not involve a wetting front, the simulation went quickly. The fluid content of the tailings reached an essentially steady-state value in a short time, much the same as for Case 5. The initial and final potential distributions are given in Figures $31 a$ and $31 b$, whereas Figures $32 a$ and $32 b$ show the initial and final moisture content distributions. Additional distribution of potentials and moisture contents at various times during the simulation are given in Appendix $G$.

The TRUST code is capable of considering soil consolidation, and although we did not use that capability in a major way in the cases run, there is no way in the version used to completely bypass all aspects of the consolidation; hence, consolidation parameters must be input. Furthermore, one of those parameters (the media compressibility) is often used to reduce numerical problems in the partially saturated regions by providing a higher capacity in the regions of transition from partially saturated to saturated flow. Such a numerical ruse has very little if any effect during normal TRUST solutions but allows for more efficient numerical solutions. There is, however, one difficulty. In its present form, TRUST only calculates total stress, and therefore, only calculates pore volumes during the initial time step. This means that pore volumes and void ratios of each material are changed at each restart of the TRUST code, causing the time history of fluxes not to be continuous. A discontinuity occurs at each restart. The magnitude of the discontinuity depends on how much the total stress changed since the last restart. The worst case observed to date in our experience is shown in Figure 33 for Case 6 . Code modifications to TRUST that have been proposed under other consolidation development work for NRC (Gates 1982) will enable complete bypassing of consolidation effects. 


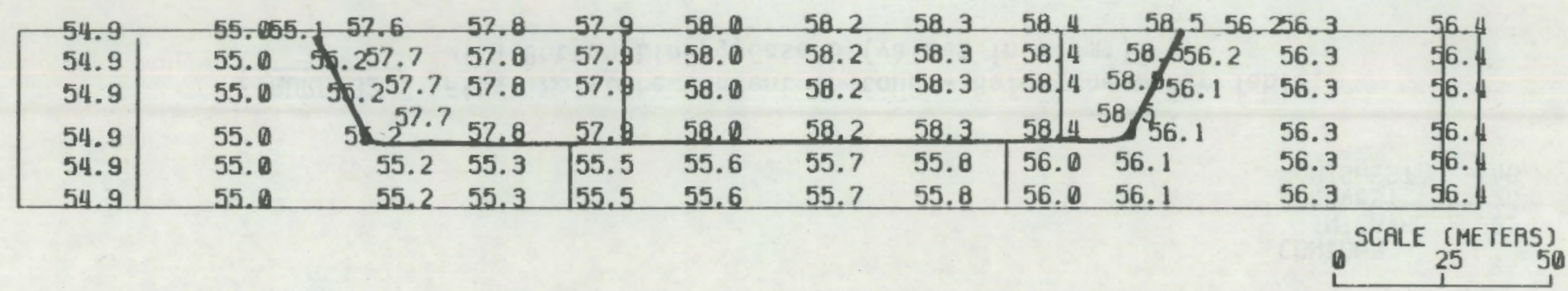

\section{CONTOUR \\ INTERVAL $=.50$ \\ LOWEST $=\dot{5} 4.50$ \\ HIGHEST $=59.00$}

FIGURE 31a. Initial Hydraulic Potential Contours--Below the Water Table, with Bottom Liner, Case 6 (values in meters)

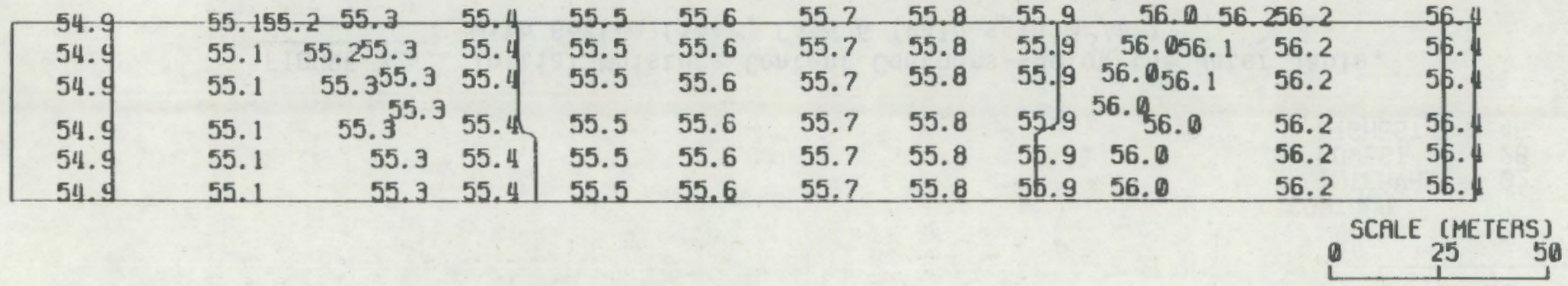

$$
\begin{aligned}
\text { CONTOUR } & \\
\text { INTERVAL } & =50 \\
\text { LOUEST } & =54.50 \\
\text { HIGHEST } & =59.00
\end{aligned}
$$

FIGURE 31b. Final Hydraulic Potential Contours--Below the Water Table, with Bottom Liner, Case 6 (values in meters) 


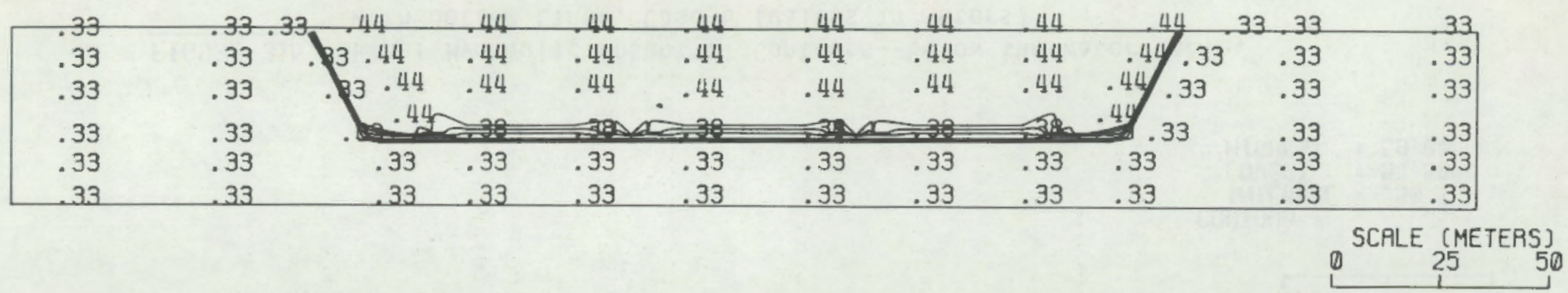

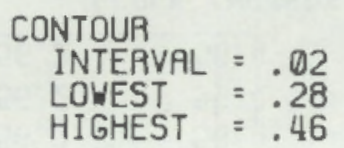

FIGURE 32a. Initial Moisture Content Contours--Belgw the Water Table, with Bottom Liner, Case 6 (values in $\mathrm{m}^{3} / \mathrm{m}^{3}$ )

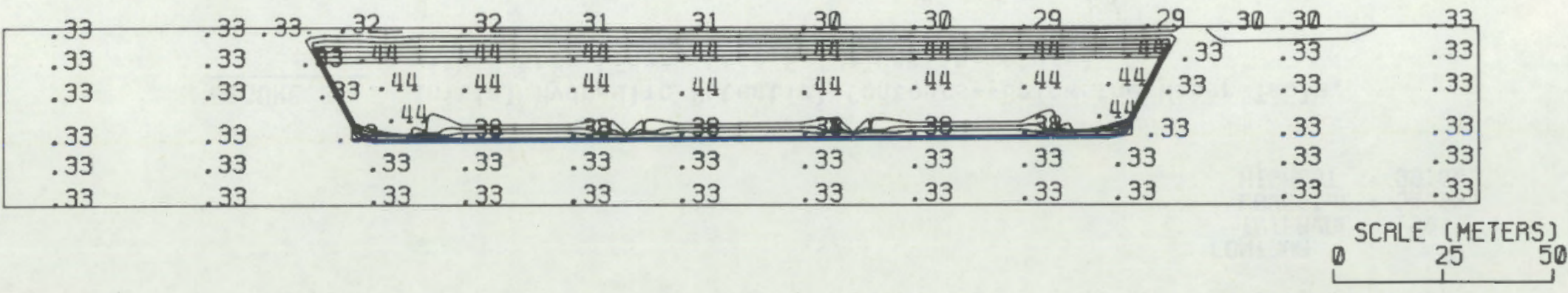

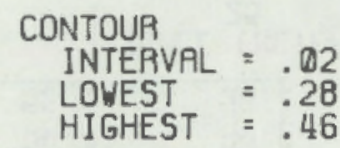

FIGURE 32b. Final Moisture Content Contours--Below the Water Table, with Bottom Liner, Case 6 (values in $\mathrm{m}^{3} / \mathrm{m}^{3}$ ) 


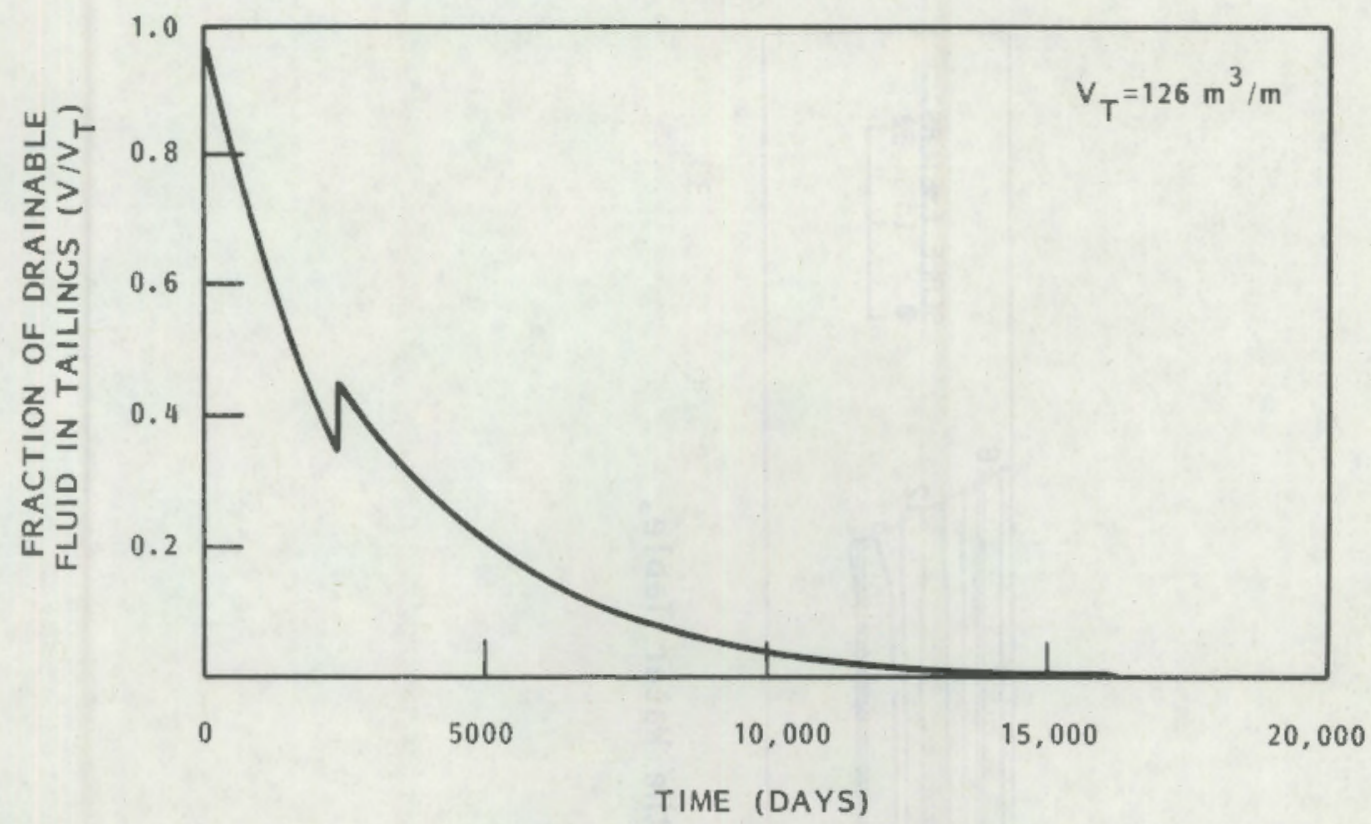

FIGURE 33. Time History of Drainable Fluid Content in Tailings-Below Water Table, Bottom Liner, Case 6

Fluid Transport Analysis

The transport analysis for Case 6 was essentially the same as for Case 5 and the results obtained were similar. The pathlines are shown in Figure 34. The bottom clay liner has a very slight isolating effect so pathlines tend to spill around the ends. Also, the fluid tends to be conveyed in the tailings just above the clay liner toward the downstream end of the liner; however, those paths do finally penetrate the liner rather than spill over its end.

The initial arrival times along pathlines at the downstream boundary were very similar to those in Case 5. Arrival was only slightly delayed at the intermediate pathlines originating along the top of the clay liner and at the upstream tailings pit boundary. In general, the clay bottom liners alone in tailings pits below the water table were of little benefit. They could be of some practical benefit during pit construction by reducing the pumpage at that time. Even that benefit may be slight, considering the difficulty of placing the liner and keeping it undisturbed until the pit is filled with tailings. 


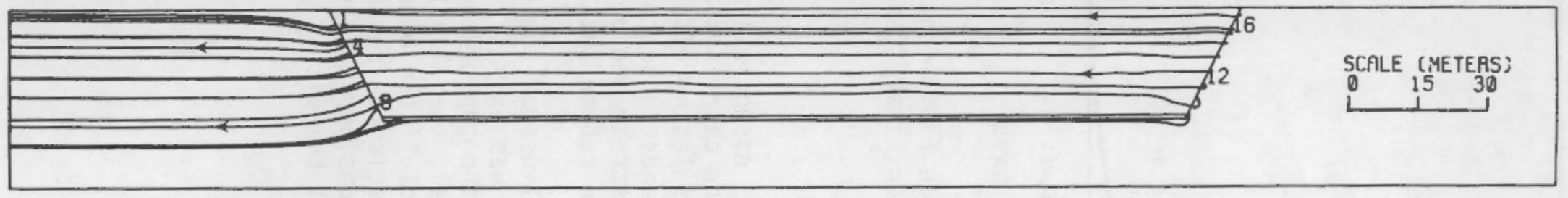

FIGURE 34. Pathlines of Tailings Leachate--Below the Water Table, with Bottom Liner, Case 6 
CASE 7--BELOW THE WATER TABLE WITH DRAINS, CLAY BOTTOM LINER, AND STUB-SIDEWALL LINERS

Case 7 is the same as Case 3 for above the water table, except that the water table was raised by $21.3 \mathrm{~m}(70 \mathrm{ft})$ to partially innundate the tailings. The water table was purposely not raised for this case to the full $27.4 \mathrm{~m}$ $(90 \mathrm{ft})$ as in the two previous cases for below the water table. If a higher water-table elevation had been used, the drawdown by the pumped drains would have a greater tendency to dominate the flow system. At lower heads the pumped drains could be less effective in controlling seepage loss out of the pit.

Flow Analysis

The flow analysis for Case 7 was set up much the same as the previous cases, through use of the TRUST code. Grid No. 1 was used, as in Case 3, with four drains installed just above the clay liner. Coarser filter material was placed around the drains to facilitate leachate movement into the drains. The clay bottom liner and stub-sidewall liners provided a saucer-shaped liner beneath the tailings. The water table was $12.2 \mathrm{~m}(40 \mathrm{ft}$ ) above the top of the clay stub-sidewall liners. The entire modeled region was tilted at a slope of 0.005 , creating a regional gradient from right to left.

The case was simulated for 5506 days ( 15.1 years) and drainage effluent was pumped for the entire period. The initial and final potential contours are shown in Figures $35 \mathrm{a}$ and $35 \mathrm{~b}$. The moisture contours are shown for the same times in Figures $36 \mathrm{a}$ and $36 \mathrm{~b}$. Additional potential and moisture content plots at intermediate times are shown in Appendix $H$.

The potential and moisture content plots show how the removal of fluid by the drains with pumping from sumps dominates and controls this case. The saucer-like bottom and stub-sidewall liners effectively assist in the fluid control. The two center drains intercept a significant part of the tailings leachate that gradually drains in time. The dominant drains are at the upstream and the downstream edge of the pit next to the clay stub-sidewall liners. These two drains tend to shield the two center drains and induce a rather complicated contaminant history in the outer drains. Both of the edge drains perform in a very similar way, so only the upstream drain is illustrated and discussed here in detail.

In the early stages of flow development, the head in the tailings is higher than in the water table outside the pit. It is also much higher than the head in the drains at edge of the pit just inside the toe of the stubsidewall liner. Thus, as illustrated in Figure 37a, initially the tailings leachate moves primarily into the drain, with a very limited amount of seepage near the edge of the tailings moving upstream out of the disposal pit. Before long, however, the drawdown in head caused by the drain reverses the flow just above the clay toe, as illustrated by Arrow A in Figure $37 \mathrm{~b}$; thus, the leachate that left the pit is pulled back into the pit and is followed by upstream ground water entering the pit. As the flow grows (illustrated by Arrow A in Figure 37b), the leachate outflow (illustrated by Arrow B) diminishes and then 


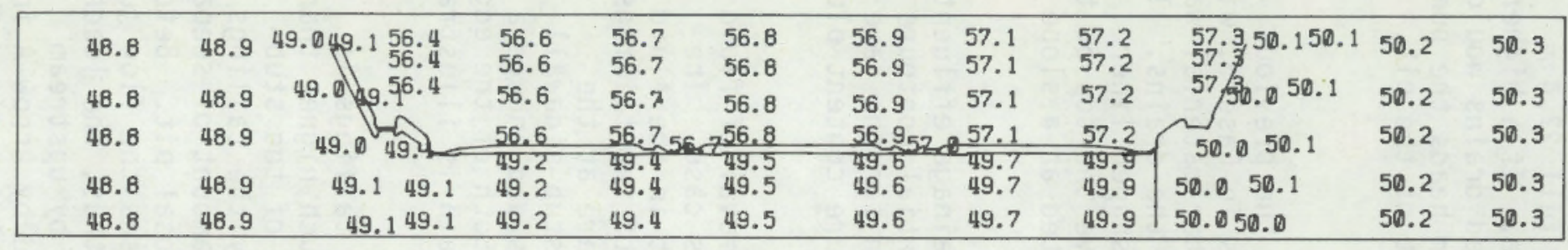

FIGURE 35a. Initial Hydraulic Potential Contours--Below the Water Table, Case 7 with Bottom Liner, Stub-Sidewalls, and Drains with Pumping (values in meters)

\begin{tabular}{|c|c|c|c|c|c|c|c|c|c|c|c|}
\hline 48.8 & 48.9 & 49.049 .652 .0 & $\begin{array}{l}52.3 \\
47.8\end{array}$ & $\begin{array}{l}52.4 \\
47.3\end{array}$ & $\frac{52.4}{46.9}$ & $\begin{array}{r}52.6 \\
47.1\end{array}$ & $\begin{array}{l}52.8 \\
47.6 \\
\end{array}$ & $\begin{array}{l}52.9 \\
40.2\end{array}$ & 52.850 .650 .1 & 50.2 & 50.3 \\
\hline 48.7 & 48.6 & $48.648 .56-4$ & 41.2 & 40.3 & 39.3 & 39.5 & 40.7 & 41.8 & 47.199 .950 .0 & 50.1 & 50.3 \\
\hline 48.7 & 48.6 & 48.64050 & 35.7 & 35.63 & $2^{35.2}$ & 35. & 536.3 & 36.6 & 50.050 .0 & 50.1 & 50.3 \\
\hline 48.7 & 48.6 & $48.6 \quad 46.6$ & $\begin{array}{l}77.5 \\
48.6\end{array}$ & 48.7 & $\begin{array}{l}47.0 \\
48.9\end{array}$ & $\begin{array}{l}47.0 \\
49.1\end{array}$ & $\begin{array}{l}40.0 \\
49.3\end{array}$ & $\begin{array}{l}40.3 \\
49.5\end{array}$ & 49.950 .0 & 50.1 & 50.3 \\
\hline 48.7 & 48.6 & 48.648 .7 & 48.6 & 49.0 & 49.2 & 49.4 & 49.6 & 49.8 & $49 \backslash 950.0$ & 50.1 & 50.3 \\
\hline & & & & & & & & & & i & chr unvas \\
\hline & & & & & & & & & & & 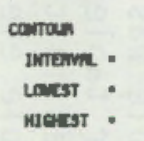 \\
\hline
\end{tabular}

FIGURE 35b. Final Hydraulic Potential Contours--Below the Water Table, Case 7 with Bottom Liner, Stub-Sidewalls, and Drains with Pumping

(values in meters) 


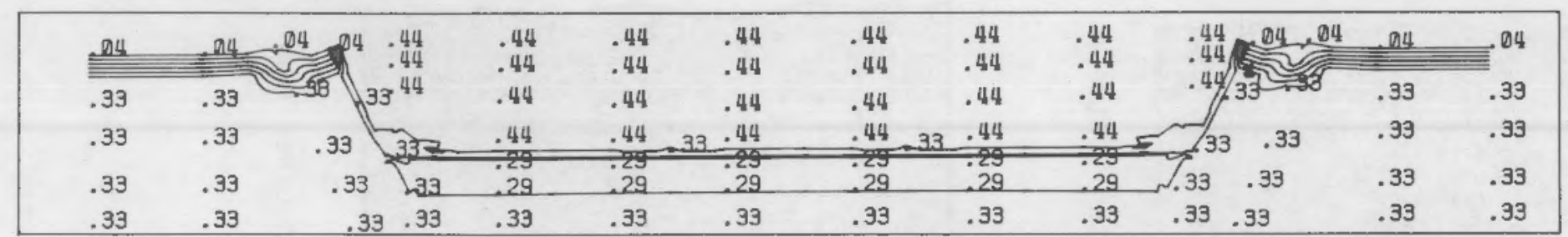

sorr catess

comran

Imenvm - .es

Lovest - D.

MIDEST - . .

FIGURE 36a. Initial Moisture Content Contours--Below the Water Table, Case 7 with Bottom Linęr, Stub-Sidewalls, and Drains with Pumping

(values in $\mathrm{m}^{3} / \mathrm{m}^{3}$ )

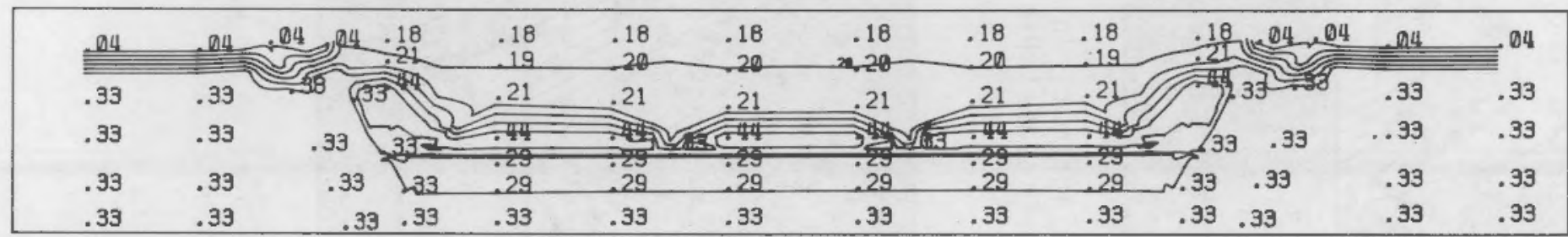

FIGURE 36b. Final Moisture Content Contours--Below the Water Table, Case 7 with Bottom Linȩr, Stub-Sidewalls, and Drains with Pumping

(values in $\mathrm{m}^{3} / \mathrm{m}^{3}$ ) 


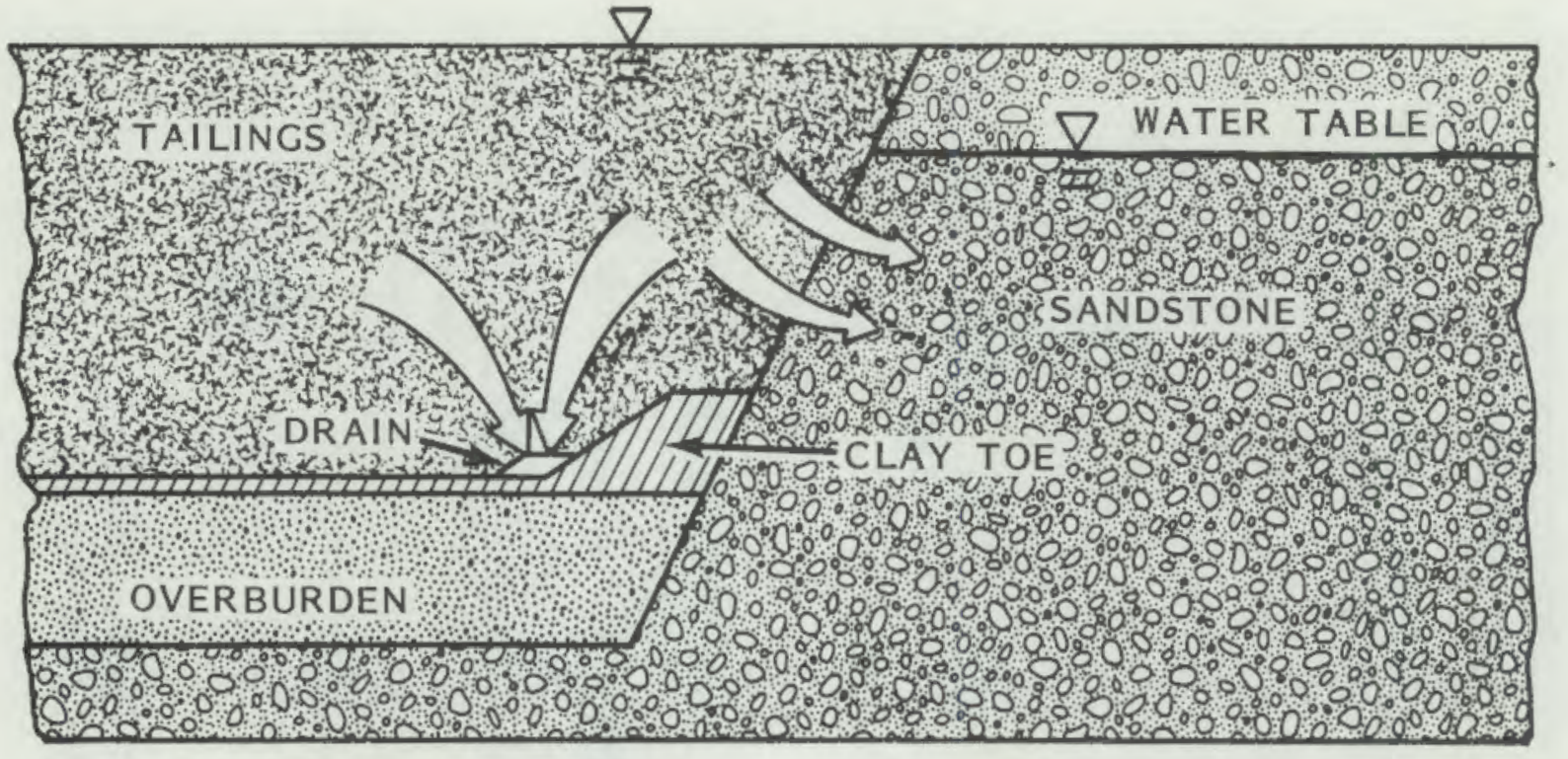

FIGURE 37a. Schematic Diagram of Initial Water Movement Near the Upstream Edge of the Disposal Pit

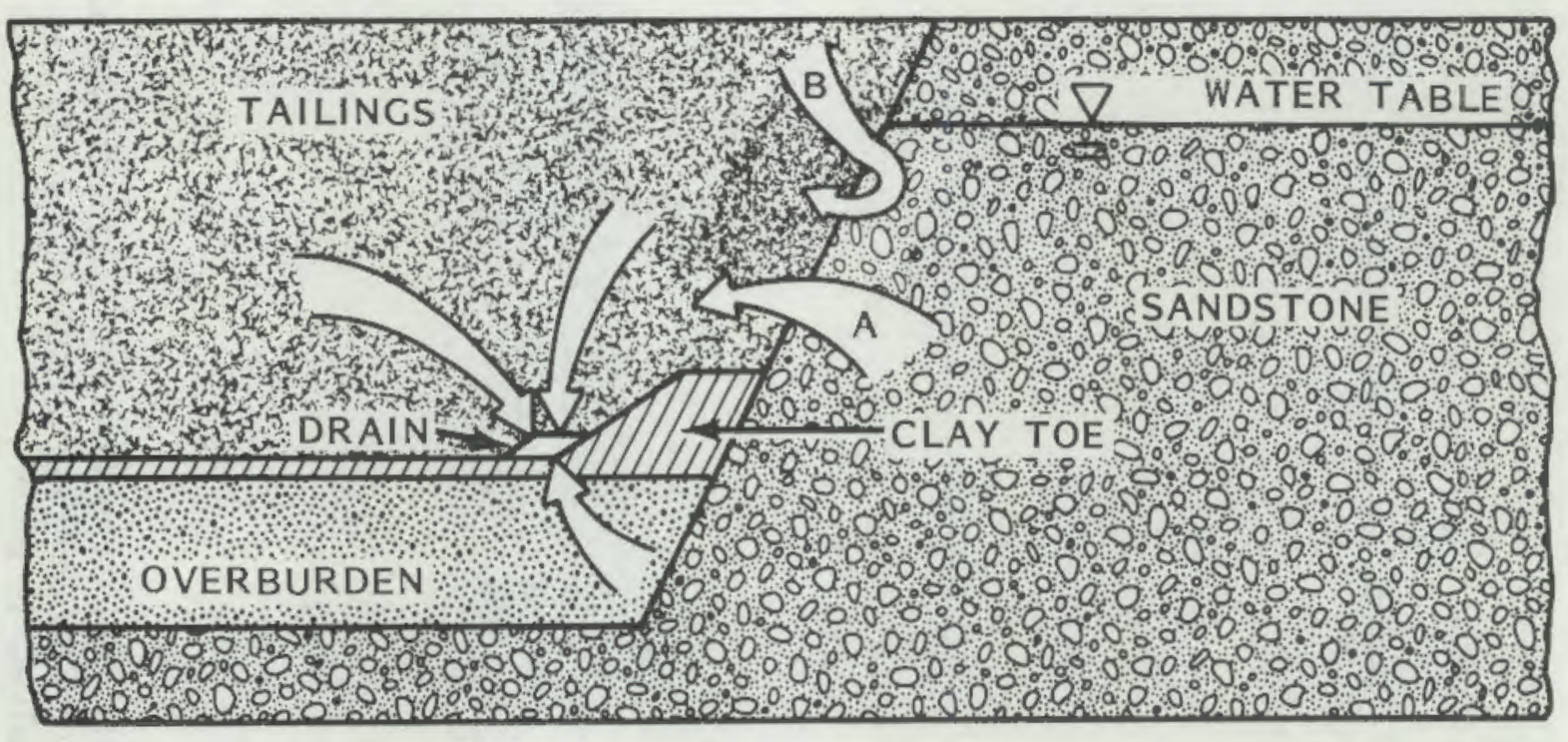

FIGURE 37b. Schematic Diagram of Water Movement a Short Time Later Near the Upstream Edge of the Disposal Pit 
reverses. In the process all of the leachate that initially seeped from the pit into the upstream sandstone returns to the tailings and later moves into the drain. As drainage toward the drain continues, some of the upstream ground water first reaches the drain and is pumped away. In fact, gradually more and more of the fluid pumped from the drain is ground water, and even smaller amounts of tailings leachate enters the two drains. Accordingly, if the pumpage from the edge drains of the pit is separate from the center drains, gradually the water quality pumped from the toe drains will become essentially that of the background quality of the ground water.

\section{Fluid Transport Analysis}

We used the MLTRAN subcodes in the fluid transport evaluation to generate the fluid velocity fields and to determine the pathlines. Along the disposal pit sidewalls several pathlines were originated at zero time (Figure 38). The leachate first moved out of the tailings a small distance (as discussed in the previous section), then returned into the tailings, and gradually proceeded into the drains at the toe of the clay stub-sidewall liner. Starting points for pathlines at zero time were also located some distance below the bottom clay liner (see Figure 38). In each instance we observed that the flow of ground water is upward through the clay bottom liner and then into the drains, showing that no leachate leaves the system. Similarly, for fluid particles selected at zero time and located horizontally toward the top of tailings, the pathlines move first downward and then laterally to the drains. In every case in Figure 38, the pathlines all indicate that the tailings leachate is finally captured by the drains. In effect, no leachate escaped the combination barrier system of drainage pumping and the bottom stub-sidewall liner.

The clay barrier and pumped sumps exercise a much better control in the saturated system than they do in the above-the-water-table Case 3 . In the saturated case the flow system can be strongly controlled by the greater drawdown at the drains. Such stronger control is not possible in the partially saturated system above the water table. A disadvantage of the case below the water table is the additional energy required for pumping over longer times to exercise the control possible. The ground water first reached the right-most (upstream) drain in Figure 38 at 137 days, and by 482 days essentially all of the water pumped from the drains near the clay toe consisted of fluid originating from the surrounding ground-water flow system, not from the tailings. At the left-most (downstream) drain, first fluid arrival was at 145 days and the last was at 489 days. 


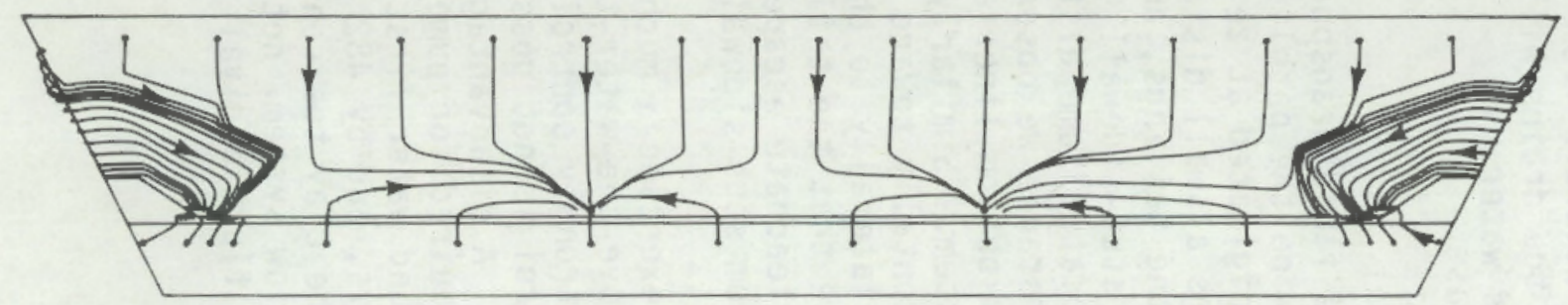

FIGURE 38. Fluid Pathlines for Below the Water Table, Case 7 with Pumped Drains, Clay Bottom Liner, and Stub-Sidewall Liners 
The results of the seven cases modeled are assembled in Table 3, which provides a detailed summary of the tailings and fluid control aspects of the four pit simulations above the water table and the three comparable simulations for below the water table. The first case in Table 3 is the Reference Case 1 with essentially no fluid control features but with initially saturated tailings disposed in an unlined pit positioned above the regional sloping water table. The results from the Reference Case 1 are used as a basis for more direct comparisons of results from the various cases. For example, Reference Case 1 had the largest total volume of tailings disposal per length of pit normal to the vertical cross-section of the pit analysed. Cases 2 and 6 represented $167 \mathrm{~m} / \mathrm{m}$ or a $3.3 \%$ reduction in tailings disposal capacity from the Reference Case 1 because the bottom clay liner material replaced some tailings.

The combination of clay stub-sidewall liners and bottom liners coupled with pumping of the effluent from the tailings drains provides the best leachate control (see Table 3, Column 6). As much as $80 \%$ of the total leachate volume that otherwise would enter ground water from disposal pits above the water table is intercepted by these combined control features. The simulations for pits below the water table with the same control combination showed essentially complete interception and control of leachate losses. The much stronger control for below-grade conditions is a result of the greater drawdown at the drains that is possible under saturated flow conditions. Noted also in Table 3, Column 9 for Cases 3,4 , and 7 is the relative amount of leachate recovery possible by pumping the drainage effluent for different periods of time. Although from 8 to $10-3 / 4$ years of pumping were needed to intercept essentially all of the leachate possible, three quarters of that total leachate was intercepted by pumping for the first year to year and a half. Thus, shorter pumping times can be very effective in controlling the total long-term leachate lost to ground water. These results apply only to the materials and pit configuration studied; however, the results do suggest that the order of 70 to $75 \%$ of the total interceptable leachate can be removed by pumping for only the first 10 to $12 \%$ of the time the drains are intercepting fluid. The results in the last four columns of Table 3 for Case 7 show that the extra water pumped over the longer pumping times is largely ground water of much better quality than the original leachate, and thus may not have the same potential for detrimental environmental effects that occur over the shorter pumping times.

On the other hand, the advantages of much better leachate control through the use of liner, drain, and pumping carry a price tag. Better leachate control involves higher construction costs, continuing energy costs for pumping, and also requires an appropriate alternative method of disposal of any leachate that may not be reused as mill process makeup water.

When no drains or effluent pumping are involved, the clay bottom liner has little advantage in terms of the total leachate lost. The benefit of the bottom clay liner is primarily in the lower leachate outflow rates (see Table 3 , Column 7); however, the leachate flows out over a much longer period of time 


\section{TABLE 3. Summary and Comparison Results from Seven Tailings Pit Disposal Cases}

Tailings Disposed per Unit Length of Pit Pits Above

1. Reference Case - Initially saturated tailings in an unlined pit with no drains but above a sloping water table

2. Similar to 1 but with a $0.9-m\left(d^{3}-f t\right)$ clay botton liner (a)

3. Similar to 2 but with clay stub-sidewall liners ang 4 drains with pumping

(a) pumping for 5 years

(b) pumping for 3 years

(2)

5107 (3)

4940

4800

167

(c) pumping for 2 years

4. Similar to 3 but with no water-table slope (i.e., no 10.75 y $\mathrm{r}$ pumping from drain

(a) pumping for 8 years

(b) pumping for 5 years

(c) pumping for 3 years

(d) pumping for 2 years

(e) pumping for 1 year

Pits Below the Water Table

5. Same as Casè 1 but water table raised $27.4 \mathrm{~m}(90 \mathrm{ft})$

6. Same as Case 2 but water tabie raised $27.4 \mathrm{~m}(90 \mathrm{ft}$ )

7. Same as Case 3 but water table raised $21.3 \mathrm{~m}(70 \mathrm{ft})$ with 8 years pumping

(a) pumping for 5 years

(b) pumping for 3 years

(d) pumping for 1 year

(a) See Figure 1.

(b) See Figure 38.

Leachate Entering Ground Water

per Unit Length of Pit Fluid Pumped from Pit per Unit Length Total Percent of Rate Away Pumped Percent of pumped Percent Volume $\frac{\text { Volume Percent Volume Reference From Pit Volume Possible Volume Excess }}{\text { Volume }}$ $\left(\mathrm{m}^{3} / \mathrm{m}\right) \quad\left(\mathrm{m}^{3} / \mathrm{m}\right)-(\mathrm{z}) \quad(\mathrm{m} / \mathrm{m})$ Case $(x) \quad(\mathrm{m} /$ day $/ \mathrm{m}) \quad\left(\mathrm{m}^{3} / \mathrm{m}\right)$ Pumpage $(\%)\left(\mathrm{m}^{3} / \mathrm{m}\right)$ Pumped $(\mathrm{z})$

$0.0 \quad 0.0$

(5)

1486

$(6)$
100.0

(7)

$0.36\left(10^{-3}\right)$

(8)
0.0

(9)

(10)

(11)

3.4

1445

97.2

$6.42\left(10^{-3}\right)$

0.0

$307 \quad 6.4$

310

20.9

$2.04\left(10^{-3}\right)$

1090

100.0

$\begin{array}{lll}-2 & -1 \\ \cdots & -- & -1\end{array}$

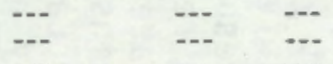

4769

289

0.1

365
419

419
474

$\begin{array}{ll}24.6 & -. \\ 28.2 & --\end{array}$

$\begin{array}{ll}28.2 & --. \\ 31.9 & --.\end{array}$

583

19.2

$-$.

$926-89.9$

926
818

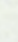

510

4948

4800

307

$0.0 \quad 0.0$

16

$6.40 .0^{(b)}$

0.0

0.0

1489

100.0

4313

289.7

$\begin{array}{llll}1408 & 94.6 & 2473 & 175.6\end{array}$

$\begin{array}{rrrr}1331 & 89.4 & 1140 & 85.7 \\ 1280 & 86.0 & 622 & 48.6\end{array}$ 
of time yielding essentially the same total outflow volume (Table 3 , Column 5). This pattern for the benefits of the clay liner is essentially the same for disposal above and below the water table, even though more leachate consistently entered the ground water from disposal pits below the water table. Specifically, based on a 100\% leachate loss for disposal above the water table, with no clay bottom liner (Case 1), the comparable loss in Case 5 (below the water table) was $142.7 \%$; the case above the water table, with a clay liner, Case 2, had a loss of $97.2 \%$ compared to $135.6 \%$ for Case 6 (below the water table with a bottom liner).

The greater leachate losses for disposal pits without drains and effluent pumping below the water table, as compared to those above the water table, represent only the leachate being physically swept from the tailings by the ground water flowing through. The losses do not consider the longer-term leaching associated with ground-water/tailings chemical interactions (i.e., those involving buffering, precipitation, solubilization, chemical reactions, mineral reactions, ion exchange, and other sorption effects occurring in the tailings leaching process). These longer-term chemical leaching effects could not be analyzed in detail in this study because not enough experimental data are available for an appropriate analysis, nor have appropriate coupled geochemical and transport models been developed. 



\section{REFERENCES}

Erikson, R. L., and D. R. Sherwood. 1982. "Interaction of Acidic Leachate with Soil Minerals at Lucky McPathfinder Mill, Gas Hills, Wyoming." In Proceedings of the Fifth Symposium on Uranium Mill Tailings Management, Civil Engr. Dept., Colorado State University, Ft. Collins, Colorado.

Foote, H. P., W. A. Rice and C. T. Kincaid. 1982. DIGRD: An Interactive Grid Generation Program. NUREG/CR-2845 (PNL-4345), U.S. Nuclear Regulatory Commission, Washington D.C.

Gates, T. E. 1982. Consolidation Theory and Its Applicability to the Dewatering and Covering of Uranium Mill Tailings. NUREG/CR-2360 (PNL-3975), U.S. Nuclear Regulatory Commission, Washington D.C.

Gee, G. W., et al. 1980a. Interaction of Uranium Mill Tailings Leachate with Soils and Clay Liners. NUREG/CR-1494 (PNL-3381), National Technical Information Service, Springfield, Virginia.

Gee, G. W., et al. 1980b. "Interaction of Uranium Mill Tailings Leachate with Morton Ranch Clay Liner and Soil Material." In Proceedings of the Third Symposium on Uranium Mill Tailings Management. Civil Engr. Dept., Colorado State University, Ft. Collins, Colorado.

Gee. G. W., et al. 1981. "Groundwater Leaching of Neutralized and Untreated Acid-Leached Uranium Mill Tailings." In Proceedings of the Symposium on Uranium Mill Tailings Management, October 26-27, 1981, Colorado State University, Ft. Collins, Colorado.

Nelson, R. W. 1978a. "Evaluating the Environmental Consequences of Groundwater Contamination, 1, An Overview of Contaminant Arrival Distributions as General Evaluation Requirements." Water Resources Research $14(3): 416-428$.

Nelson, R. W. 1978b. "Evaluating the Environmental Consequences of Groundwater Contamination, 2, Obtaining Location/Arrival Time and Location/Outflow Quantity Distribution for Steady Flow Systems." Water Resources Research 14(3):416-428.

Nelson, R. W. 1978c. "Evaluating the Environmental Consequences of Groundwater Contamination, 3, Obtaining Contaminant Arrival Distributions for Steady Flow in Heterogeneous Systems." Water Resources Research $14(3): 429-440$.

Nelson, R. W. 1978d. "Evaluating the Environmental Consequences of Groundwater Contamination, 4, Obtaining and Utilizing Contaminant Arrival Distributions in Transient Flow Systems." Water Resources Research $14(3): 441-450$. 
Nelson, R. W., A. E. Reisenauer and G. W. Gee. 1980. Model Assessment of Alternatives for Reducing Seepage of Contaminants from Buried Uranium Mil 1 Tailings at the Morton Ranch Site in Central Wyoming. PNL-3378, Pacific Northwest Laboratory, Richland, Washington.

NRC. 1980. Final Environmental Impact Statement on Uranium Milling. Vol. 1, NUREG-0706, U.S. Nuclear Regulatory Commission. Washington, D.C.

Reisenauer, A. E., et al. 1982. TRUST: A Computer Program for Variably Saturated Flow in Multidimensional, Deformable Media. NUREG/CR-2360 (PNL-3975), U.S. Nuclear Regulatory Commission, Washington D.C.

Relyea, J. F., and W. J. Martin. 1982. "Evaluation of Inactive Uranium Mill Tailings Sites for Liner Requirements: Characterization and Interaction of Tailings, Soil and Liner Materials." In Proceedings of the Fifth Symposium on Uranium Mill Tailings Management, CiviT Engr. Dept., Colorado State University, Ft. Collins, Colorado.

Scarano, R. A. 1980. "Review of Uranium Mill Tailings Management Programs Involving Below Grade Disposal." In First International Conference on Uranium Mine Waste Disposal, May 19-21, 1980, ed. C. 0. Brawner, Vancouver, Canada. 
APPENDIX A

NOTATION 


\section{APPENDIX A}

\section{NOTATION}

$$
\begin{aligned}
C= & \text { Concentration } \\
& \left(\text { Units: } M / L^{3}\right) \\
g= & \text { Acceleration due to gravity } \\
& \left(\text { units: } L / T^{2}\right) \\
k= & \text { Inrinsic Permeability } \\
& \text { (Units: } \left.L^{2}\right)
\end{aligned}
$$

K Hydrautic Conductivity

(Units: $L / T$ )

$$
\begin{aligned}
Q= & \text { Volumetric flow rate } \\
& \text { (Units: } L^{3} / T \text { ) }
\end{aligned}
$$$$
s=\underset{\text { Saturation }}{ }{\text { (Units: } L^{3} / L^{3} \text { ) }}^{\text {Units }}
$$$$
\mathrm{t}=\text { Time }
$$$$
\text { (Units: T) }
$$

$$
\begin{gathered}
W=\underset{\text { Mass fluid flow rate }}{ } \\
(\text { Units: } M / T \text { ) }
\end{gathered}
$$

$W_{S}=$ Mass outflow rate of sulfate (Units: $M / T$ )

$$
q=\underset{\text { unit fluid outf low }}{\text { (Units: } L / T / L^{2} \text { ) }}
$$

$$
\begin{aligned}
S_{1}= & \text { The minimum or lower outflow } \\
& \text { locations, for example, from } \\
& \text { Figure } 28 \text { (Units: L) }
\end{aligned}
$$
$S_{2}=$ The upper or maximum outflow location, for example from
Figure 28 (Units: L)

$$
\begin{aligned}
V= & \text { Volume of fluid that has } \\
& \text { drained from the tailings } \\
& \text { per unit pit length } \\
& \text { (Units: } \mathrm{m} / \mathrm{m} \text { ) }
\end{aligned}
$$




$$
\begin{aligned}
& V_{T}= \text { Total volume of drainable fluid } \\
& \text { in the tailings } \mathrm{per} \text { unit pit } \\
& \text { length (Units: } \mathrm{m} / \mathrm{m} \text { ) } \\
& \mu= \begin{array}{l}
\text { Dynamic viscosity } \\
\text { (Units: M/LT) }
\end{array} \\
& \rho= \text { Mass density } \\
& \text { (Units: } \mathrm{M} / \mathrm{L}^{3} \text { ) }
\end{aligned}
$$


APPENDIX B

POTENTIAL AND MOISTURE CONTENT PLOTS: REFERENCE CASE 1 


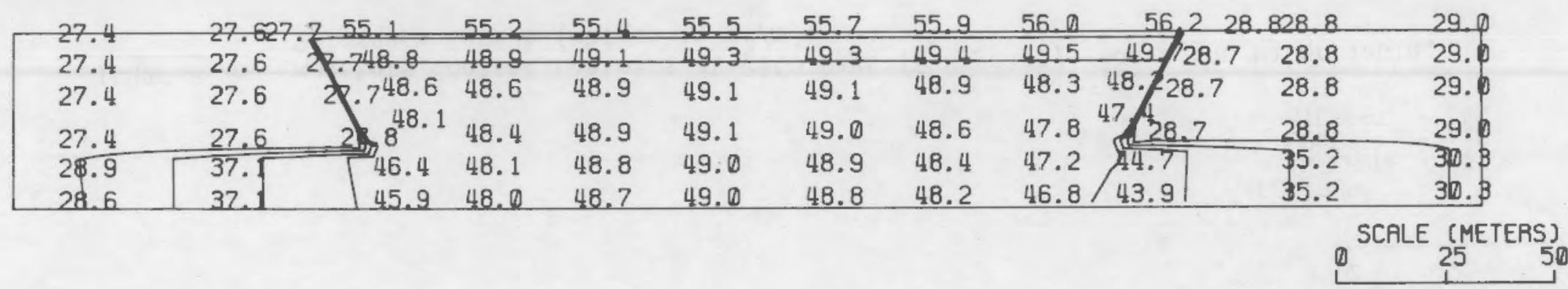

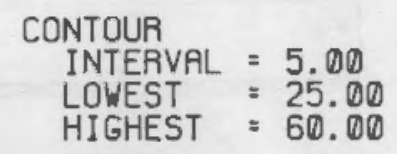

FIGURE B.1a. Hydraulic Potential Contours at 1575 Days ( 4.3 years)--Above the Water Table, Reference Case 1 (values in meters)

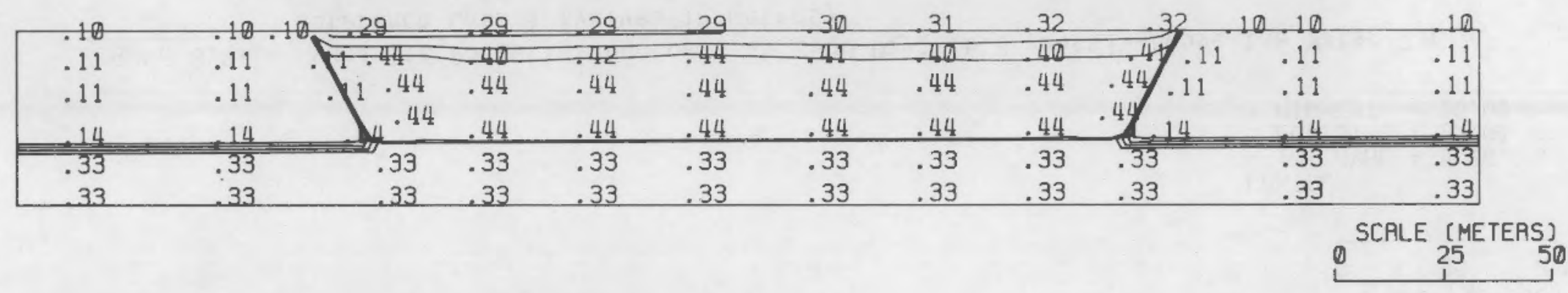

CONTOUA

INTEAVAL $=.05$

HIGHEST $=.45$

FIGURE B.1b. Moisture Content Contours at 1575 Days (4.3 years)--Above the Water Table, Reference Case 1 (values in $\mathrm{m}^{3} / \mathrm{m}^{3}$ ) 


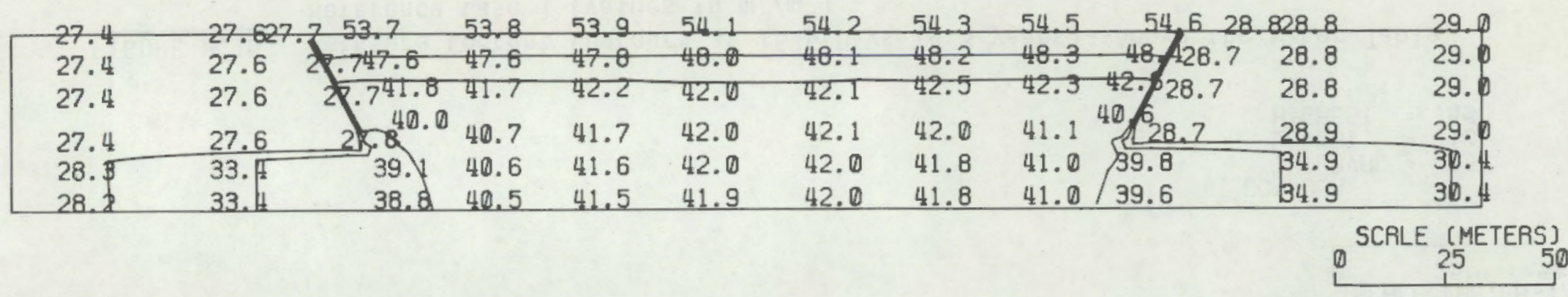

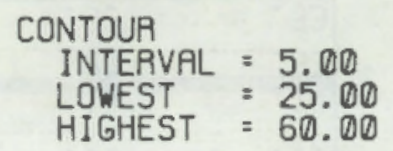

FIGURE B.2a. Hydraulic Potential Contours at 2500 Days (6.8 years)--Above the Water Table, $\stackrel{\infty}{\sim}$ Reference Case 1 (values in meters)

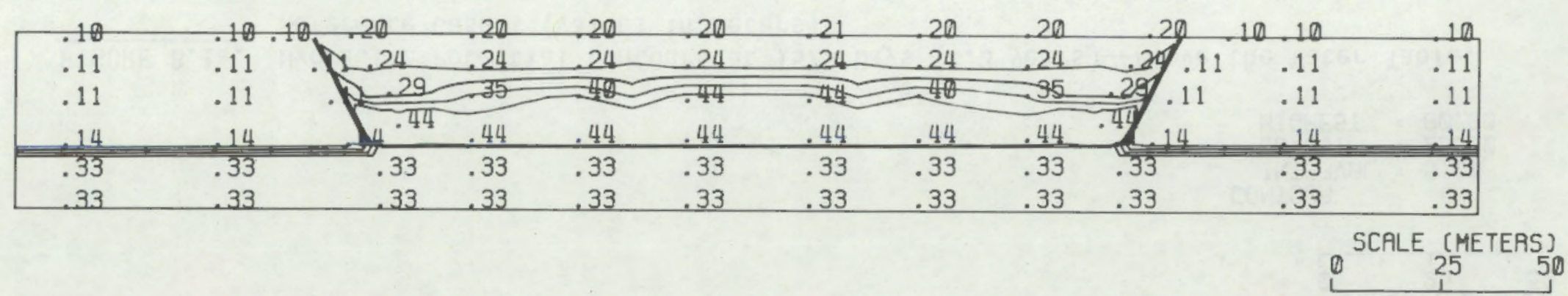

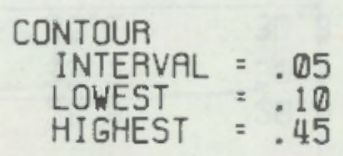
FIGURE B.2b. Moisture Content Contours at 2500 Days ( 6.8 years)--Above the Water Table,
Reference Case 1 (values in $\mathrm{m}^{3} / \mathrm{m}^{3}$ ) 


\begin{tabular}{|c|c|c|c|c|c|c|c|c|c|c|}
\hline 27.4 & 27.62 & 53.3 & 53.5 & 53.6 & 53.8 & 53.9 & 54.0 & 54,12 & 828.8 & \\
\hline 27.4 & 27.6 & 47.1 & 47.2 & 47.3 & 47.4 & 47.6 & 47.7 & 6.028 .7 & 28.8 & \\
\hline 27.4 & 27.6 & 41.0 & $41.2 \cdot$ & 40.4 & 40.5 & 41.6 & 41.6 & 28.7 & 28.8 & \\
\hline 27.4 & 27.7 & 35.0 & 35.6 & 36.1 & 36.2 & 36.0 & & & 28.9 & \\
\hline 27.9 & 30.8 & 34.9 & 35.6 & 36.0 & 36.2 & 35.9 & 35.4 & 34.7 & 32.2 & \\
\hline 27. 8 & 30.8 & 34.8 & 35.6 & 36.0 & 36.1 & 35.9 & $35.4 /$ & 34.6 & 32.2 & \\
\hline
\end{tabular}
SCRLE [METERS]

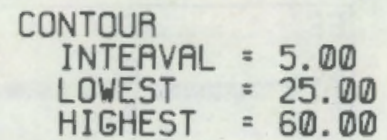

FIGURE B.3a. Hydraulic Potential Contours at 3437 Days (9.4 years)--Above the Water Table, Reference Case 1 (values in meters)

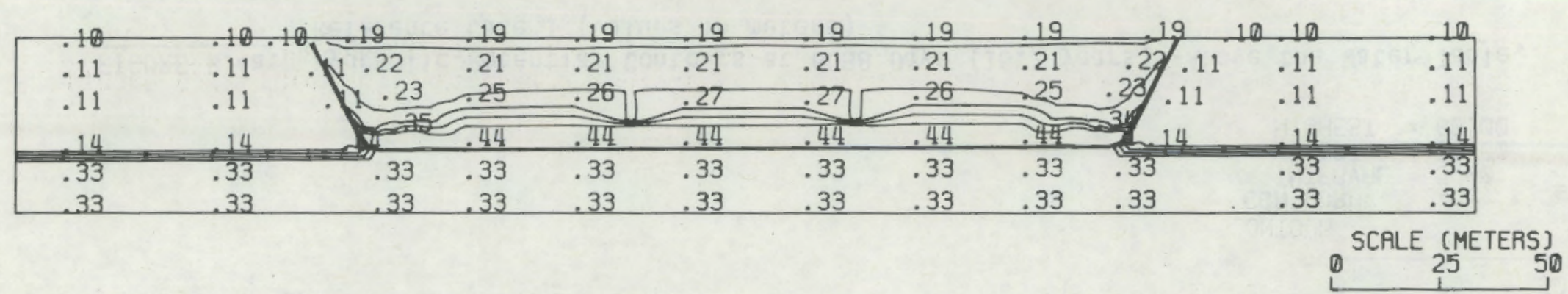

CONTOUA
INTERVAL $=.05$
LOWEST $=.10$
HIGHEST $=.45$

FIGURE B.3b. Moistune Content Contours at 3437 Days $(9.4$ years)-Above the Water Table, Reference Case 1 (values in $\mathrm{m}^{3} / \mathrm{m}^{3}$ ) 


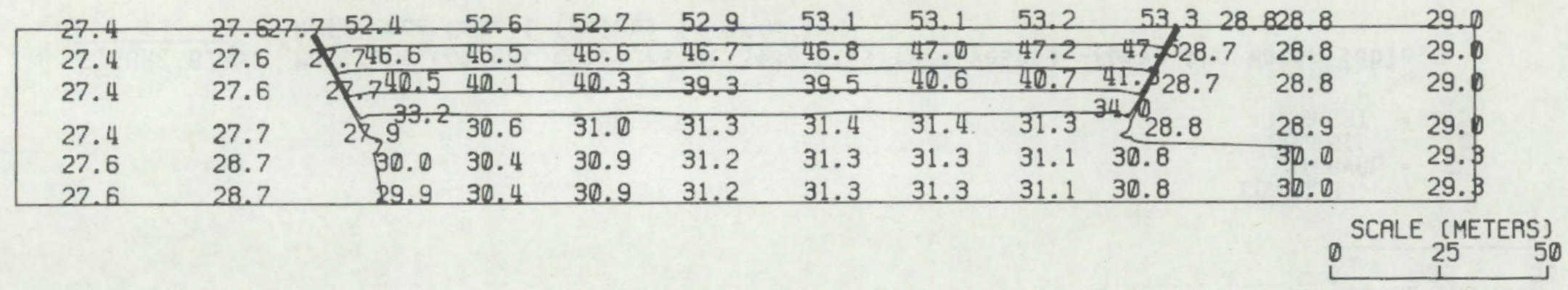

CONTOUR

INTERVAL $=5.00$

LOWEST $=25.00$

HIGHEST $=60.00$

FIGURE B.4a. Hydraulic Potential Contours at 6088 Days (16.7 years)--Above the Water Table, Reference Case 1 (values in meters)

:

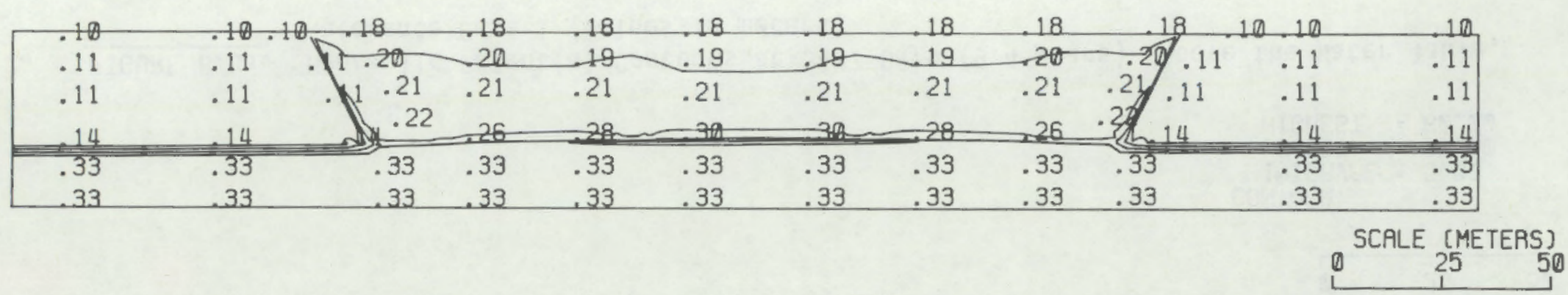

$\begin{aligned} \text { CONTOUR } & \\ \text { INTERVAL } & =.05 \\ \text { LOWEST } & =.10 \\ \text { HIGHEST } & =.45\end{aligned}$

FIGURE B.4b. Moisture Content Contours at 6088 Days ( 16.7 years)--Above the Water Table, Reference Case 1 (values in $\mathrm{m}^{3} / \mathrm{m}^{3}$ ) 


\begin{tabular}{|c|c|c|c|c|c|c|c|c|c|c|c|}
\hline 27.4 & 27.82 & 46.1 & 45.9 & 46.1 & 46.2 & 46.3 & 46.4 & 46.6 & 47,28 & 828.8 & 29.0 \\
\hline 27.4 & 27.6 & .742 .2 & 41.6 & $41 . \overline{8}$ & 41.6 & 41.8 & 42.2 & 42.3 & $3 y / 28.7$ & 28.8 & 29.6 \\
\hline 27.4 & 27.6 & & 37.0 & 37.4 & 36.6 & 36.8 & 37.8 & 37.6 & 428.7 & 26.8 & \\
\hline 27.4 & 27.7 & $2 \times 9^{32.3}$ & 31.2 & 31.2 & 31.3 & 31.4 & 31.6 & 31.7 & 26.9 & 28.9 & \\
\hline 27.4 & 27.6 & 27.9 & 28.0 & 28.2 & 28.3 & 28.5 & 28.6 & 28.7 & 28.8 & 28.9 & \\
\hline 27.4 & 27.6 & 27.9 & 28.0 & 28.2 & 28.3 & 28.5 & 28.6 & 28.7 & 28.8 & 28.9 & \\
\hline
\end{tabular}

$0^{\text {SCALE }}{ }_{25}^{\text {(METERS) }}$

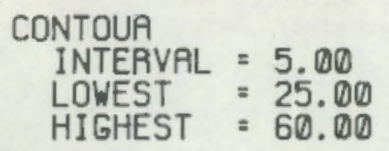

FIGURE B.5a. Hydraulic Potential Contours at 42,522 Days (116.5 years)--Above the Water Table, Reference case 1 .(values in meters)

is

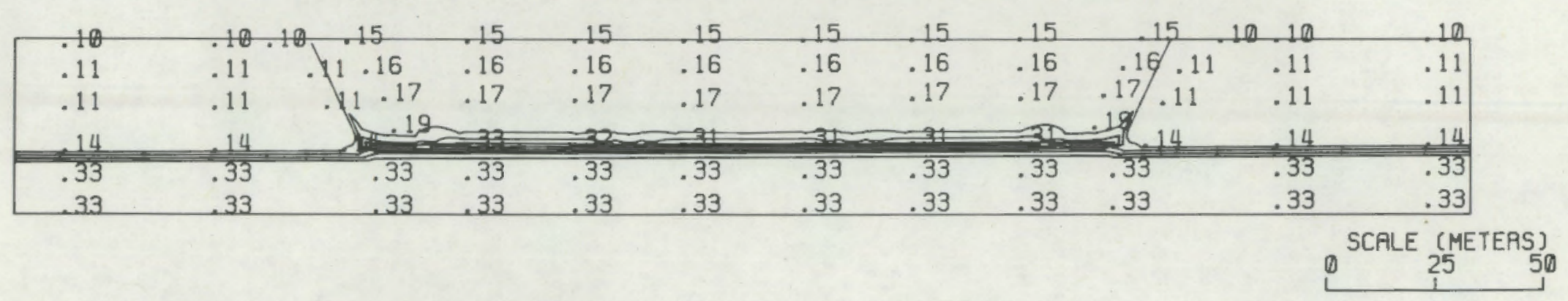
CONTOUR
INTERVAL $=.05$
LOWEST $=.10$
HIGHEST $=.45$

FIGURE B.5b. Moisture Content Contours at 42,522 Days (116.5 years)--Above the Water Table, Reference Case 1 (values in $\mathrm{m}^{3} / \mathrm{m}^{3}$ ) 



\section{APPENDIX C}

POTENTIAL AND MOISTURE CONTENT PLOTS:

CASE 2 WITH CLAY BOTTOM LINER 


\begin{tabular}{|c|c|c|c|c|c|c|c|c|c|c|}
\hline 27.4 & 27.027. & 3.6 & 53.7 & 53.8 & 54.0 & 54.1 & 54.1 & $54.3 \quad 54,42$ & 328.8 & 29.0 \\
\hline 27.4 & 27.6 & 249.0 & 49.0 & 49.1 & -49.2 & 49.3 & 149.4 & $49.5 \quad 49,628.7$ & 28.8 & 29.6 \\
\hline 27.4 & 27.6 & .748 .9 & 49.0 & 49.0 & 49.1 & 49.2 & 49.4 & $49.4 \quad 49.828 .7$ & 28.8 & 29.6 \\
\hline 27.4 & 27.6 & $8^{48.9}$ & 044 & 44.5 & 44.2 & 141,8 & 44.9 & $44.89 / 28.7$ & 28.8 & 29.6 \\
\hline 27.7 & 28.8 & 30.0 & 30.5 & 31.0 & 31.3 & 31.4 & 31.4 & 30.8 & 30.0 & $29 . \beta$ \\
\hline 27.7 & 28.8 & 30.0 & 30.5 & 31.0 & 31.3 & 31.4 & 31.3 & $31.1 \quad 30.8$ & 30.0 & 29. 3 \\
\hline
\end{tabular}
CONTOUR
INTERVRL $=5.00$
LDWEST $=25.00$
LDWEST $=25.00$
HIGHEST $=60.00$

FIGURE C.1a. Hydraulic Potential Contours at 4852 Days (13.3 years)--Above the Water Table, Case 2 with Clay Bottom Liner (values in meters)

?

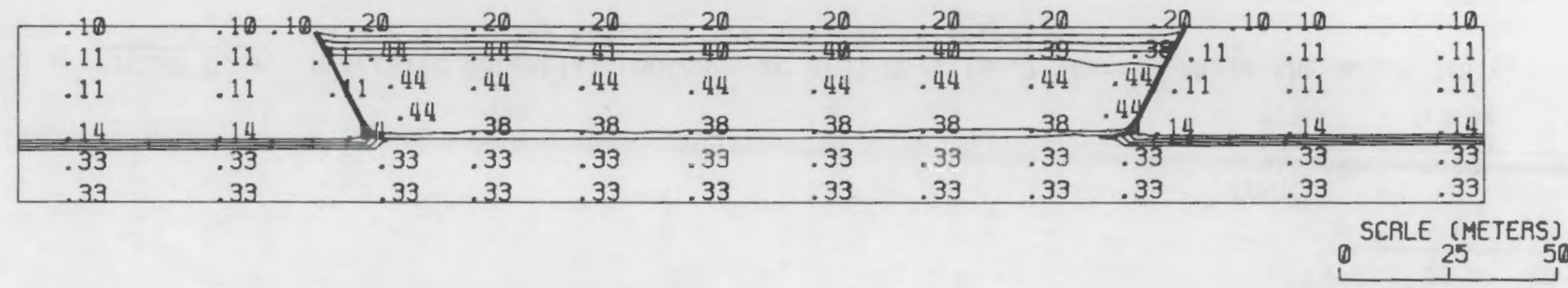

CONTOUR

INTERVAL $=.05$

LOWEST $=.10$

HIGHEST $=.45$

FIGURE C.1b. Moisture Content Contours at 4852 Days $(13,3$ years)-Above the Water Table, Case 2 with Clay Bottom Liner (values in $\mathrm{m}^{3} / \mathrm{m}^{3}$ ) 


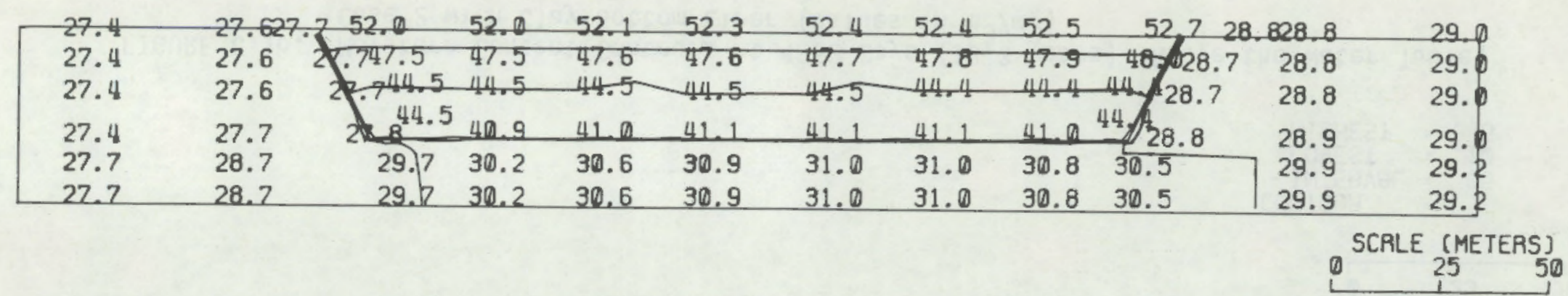

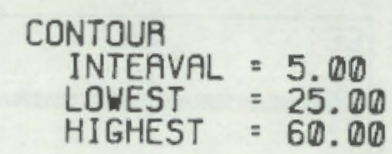

FIGURE C.2a. Hydraulic Potential Contours at 9731 Days (26.7 years)--Above the Water Table, Case 2 with Clay Bottom Liner (values in meters)

$\overbrace{i}$

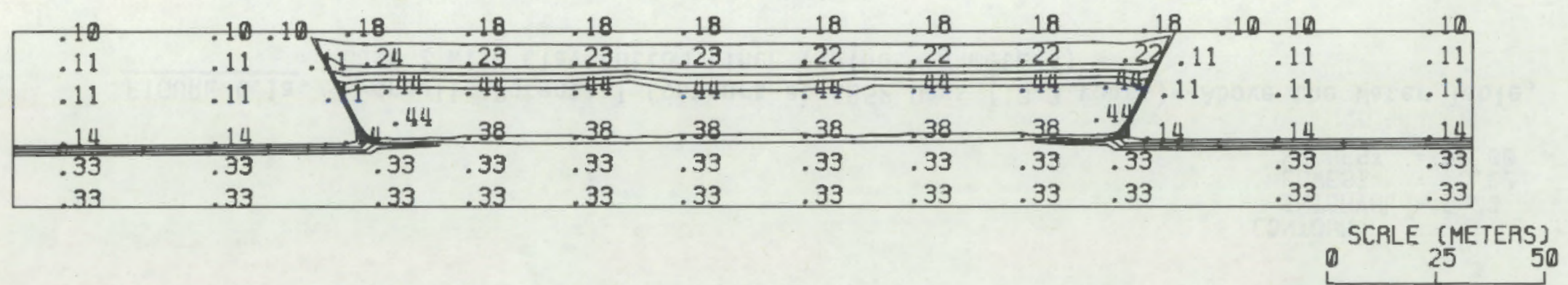

$$
\begin{aligned}
& \text { CONTOUA } \\
& \text { INTERVAL }=.05 \\
& \text { LOWEST }=.10 \\
& \text { HIGHEST }=.45
\end{aligned}
$$

FIGURE C.2b. Moisture Content Contours at 9731 Days $\left(26_{3} 7\right.$ years)--Above the Water Table, Case 2 with $\mathrm{Clay}$ Bottom Liner (values in $\mathrm{m}^{3} / \mathrm{m}^{3}$ ) 


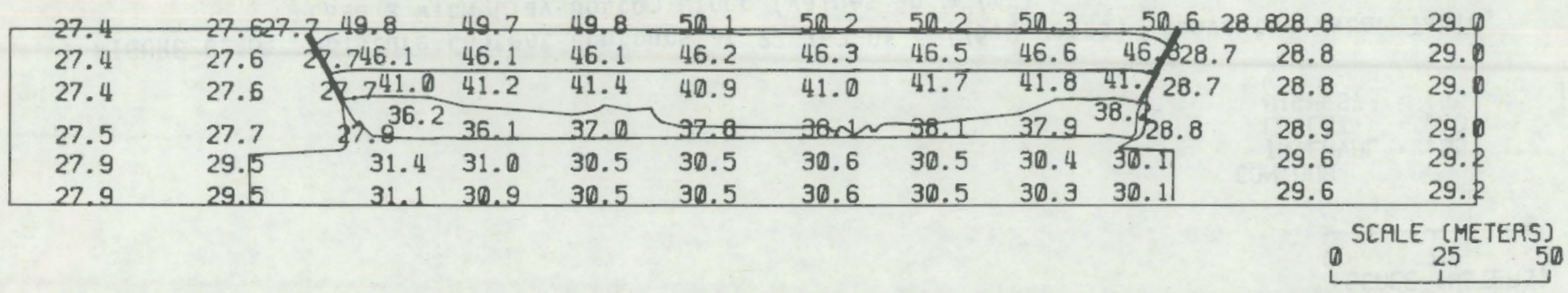

CONTOUR

INTERVAL $=5.00$

OVEST $=25.00$

HIGHEST $=60.00$

FIGURE C.3a. Hydraulic Potential Contours at 15,479 Days (42.4 years)--Above the Water Table,

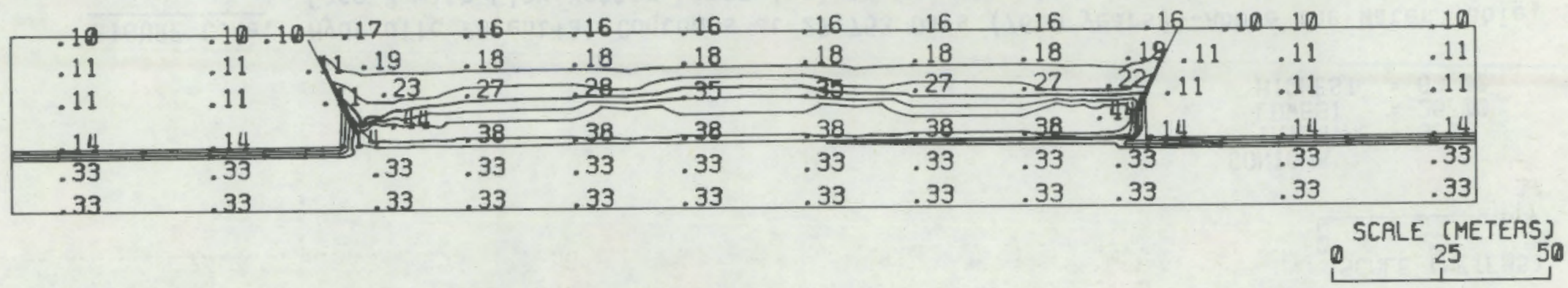

CONTOUR

INTERVAL $=.05$

LOWEST $=.10$

HIGHEST $=.45$

FIGURE C.3b. Maisture Content Contours at 15,479 Days ( 42.4 years)--Above the Water Table, Case 2 with C.lay ibottom Liner (values in $\mathrm{m}^{3} / \mathrm{m}^{3}$ ) 


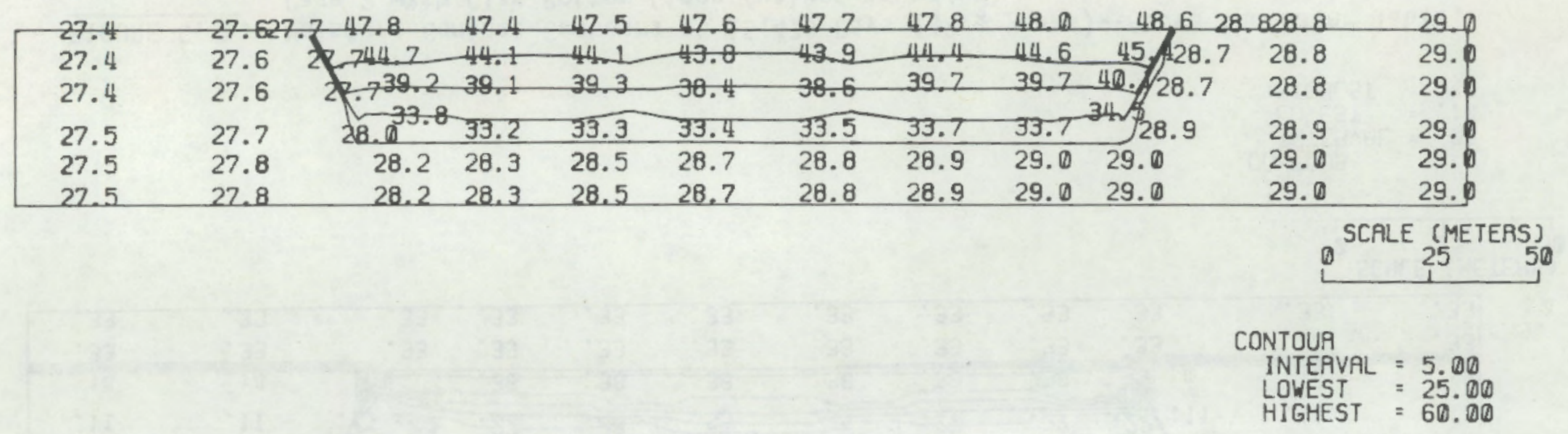

FIGURE C.4a. Hydraulic Potential Contours at 27,753 0ays (76.0 years)--Above the Water Table, Case 2 with Clay Bottom Liner (values in meters)

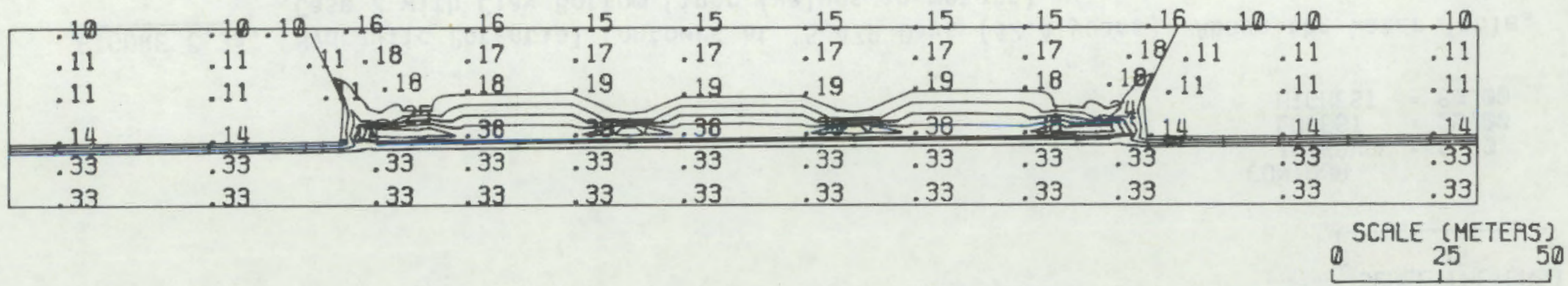

CONTOUR
INTERVAL $=.05$
LOWEST $=.10$
HIGHEST $=.45$

FIGURE C.4b. Moisture Content Contours at 27,753 Days ( 76.0 years)--Above the Water Table, Case 2 with Clay Bottom Liner (values in $\mathrm{m}^{3} / \mathrm{m}^{3}$ ) 


\begin{tabular}{|c|c|c|c|c|c|c|c|c|c|c|c|}
\hline 27.4 & 27.62 & 246,0 & 45.7 & 45.8 & 46. 0 & 46.1 & 46.2 & 46.4 & 46,92 & 828.8 & 29.9 \\
\hline 27.4 & 27.6 & 7.742 .0 & 41.4 & 41.5 & 41.3 & 41.4 & 41.9 & 42.0 & $42,628.7$ & 28.8 & 29.6 \\
\hline 27.4 & 27.6 & 4.737 .4 & 37.1 & 37.5 & 36.7 & 36.8 & 37.8 & 37.6 & $8 . / 28.7$ & 28.8 & 29.6 \\
\hline 27.5 & 27.7 & $28.0^{33.1}$ & 32.2 & 32.3 & 32.4 & 32.5 & 32.6 & 32.8 & 28.9 & 28.9 & 29.6 \\
\hline 27.5 & 27.7 & 28. & 28.1 & 28.3 & 28.4 & 28.5 & 28.6 & 28.7 & 28.8 & 28.9 & 29.0 \\
\hline 27.5 & 27.7 & 28.0 & 28.1 & 28.2 & 28.4 & 28.5 & 28.6 & 28.7 & 28.8 & 28.9 & 29.0 \\
\hline
\end{tabular}

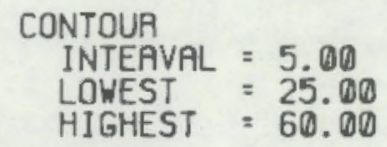

FIGURE C.5a. Hydraulic Potential Contours at 46,896 Days (128.5 years)--Above the Water Table, Case 2 with 6 lay Bottom Liner (values in meters)

is

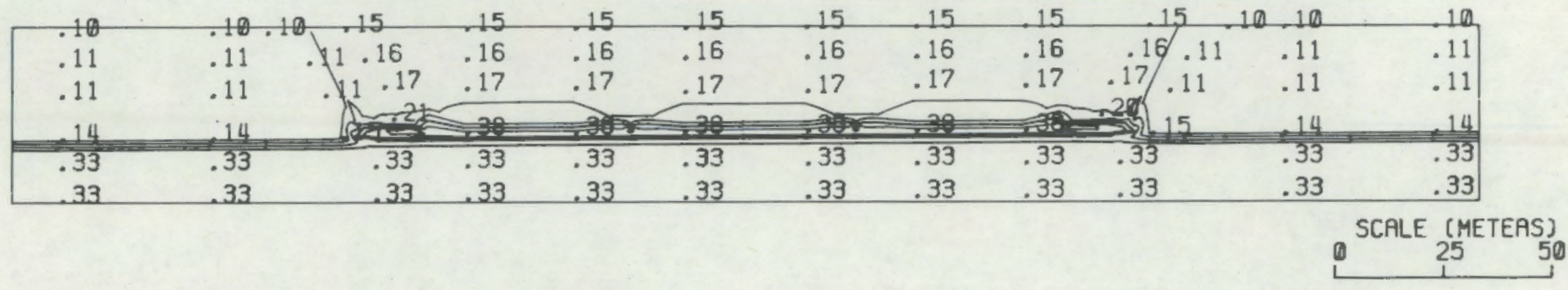

CONTOUR

INTERVRL $=.05$

LOUEST $=.10$

HIGHEST $=.45$

FIGURE C.5b. Moisture Content Contours at 46,896 Days $(128,5$ years)--Above the Water Table, Case 2 with Clay Bottom Liner (values in $\mathrm{m}^{3} / \mathrm{m}^{3}$ ) 


\section{APPENDIX D}

POTENTIAL AND MOISTURE CONTENT PLOTS:

CASE 3 WITH CLAY BOTTOM AND STUB-SIOEWALL LINERS WITH ORAINS 


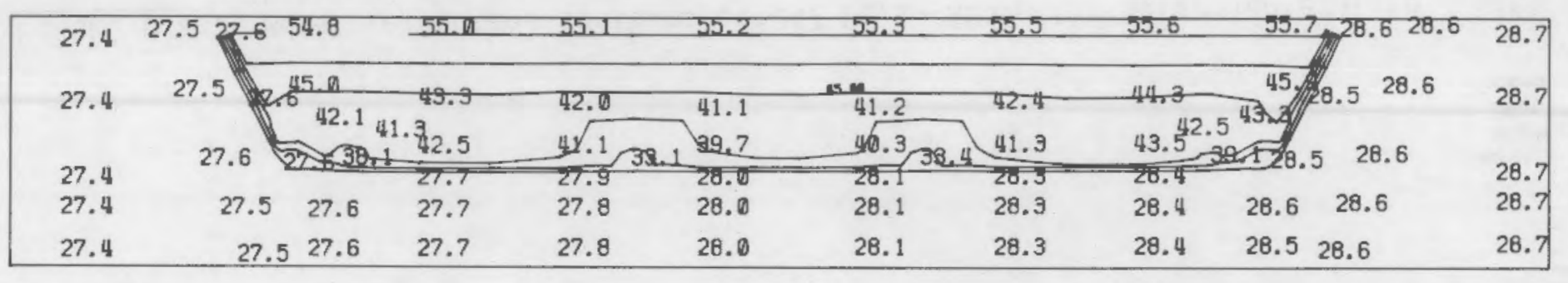

FIGURE D.la. Hydraulic Potential Contours at 33.6 Days--Above the Water Table, Case 3 with Clay Bottom and Stub-Sidewall Liners with Drains (values in meters)

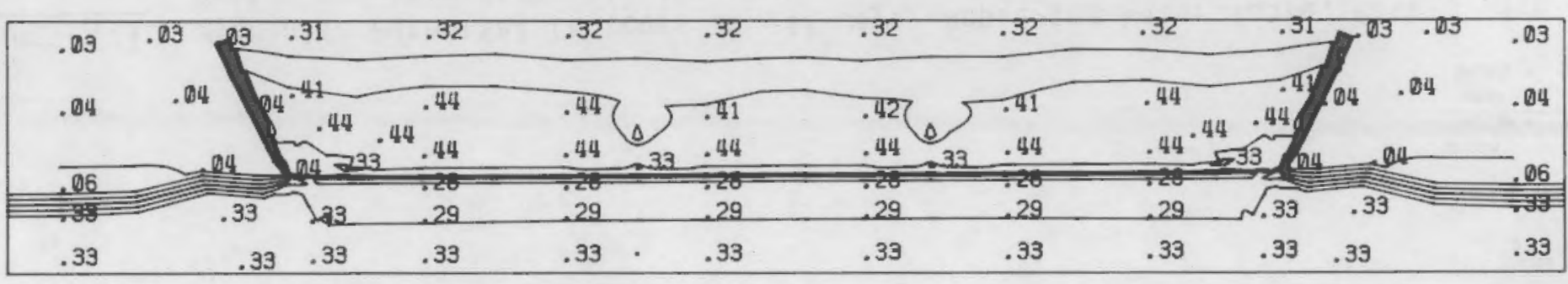

FIGURE D.1b. Moisture Content Contours at 33.6 Days--Above the Water Table ${ }_{3}$ Case 3 with Clay Bottom and Stub-Sidewall Liners with Drains (values in $\mathrm{m}^{3} / \mathrm{m}^{3}$ ) 


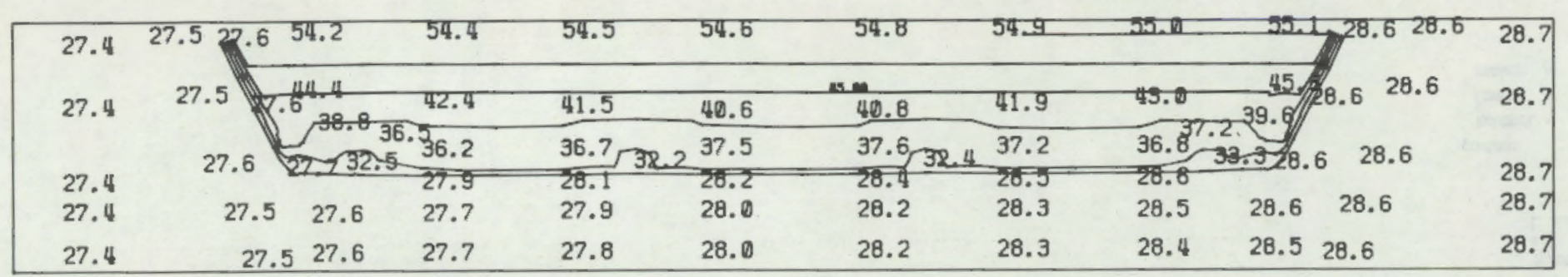

FIGURE D.2a. Hydraulic Potential Contours at 247 Days--Above the Water Table, Case 3 with Clay Bottom and Stub-Sidewall Liners with Drains (values in meters)

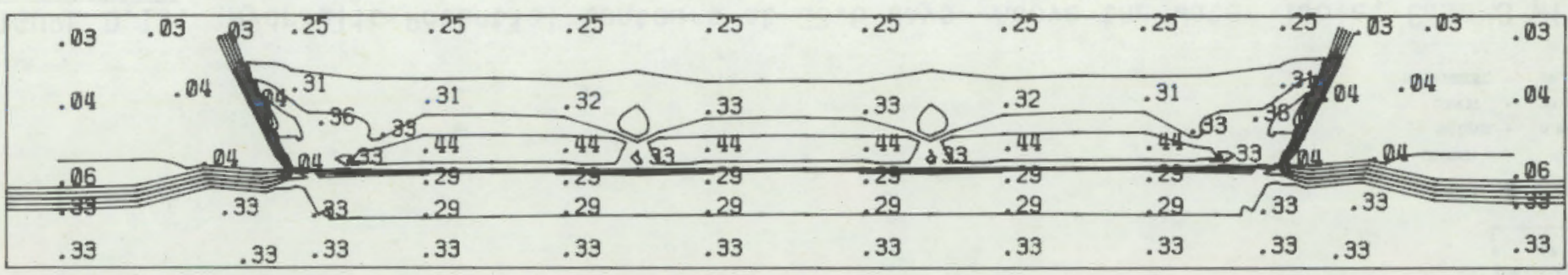

FIGURE D.2b. Moisture Content Contours at 247 Days--Above the Water Tąble Bottom and Stub-Sidewall Liners with Drains (values in $\mathrm{m}^{3} / \mathrm{m}^{3}$ ) 


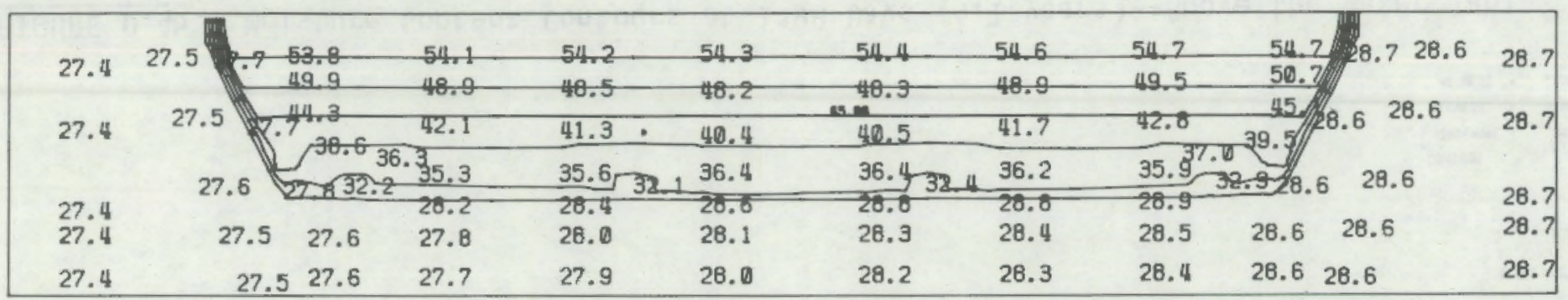

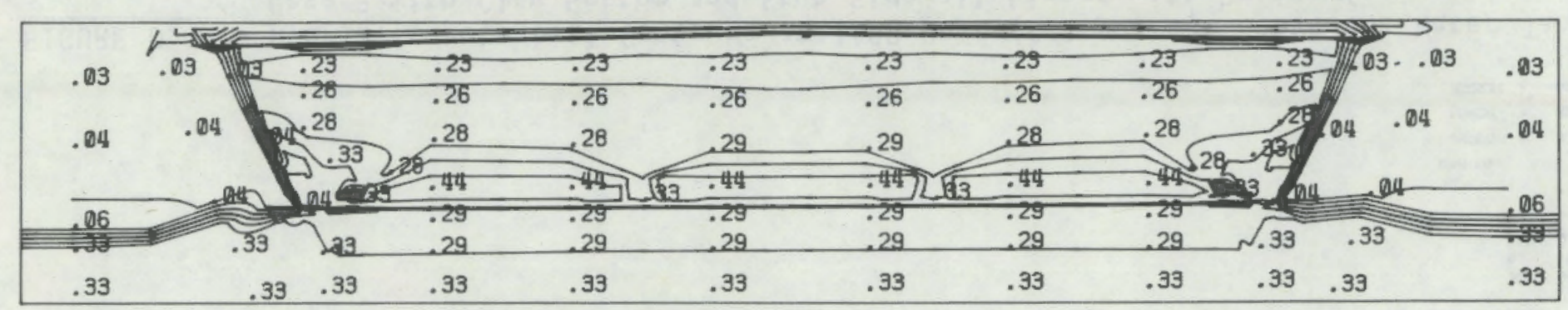

intume. 5.0

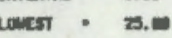

nercs - "..

\section{FIGURE D.3a. Hydraulic Potential Contours at 513 Days ( 1.4 years)--Above the Water Table,
Case 3 with Clay Bottom and Stub-Sidewall Liners with Drains (values in meters) \\ FIGURE D.3a. Hydraulic Potential Contours at 513 Days (1.4 years)--Above the Water Table,
Case 3 with Clay Bottom and Stub-Sidewall Liners with Drains (values in meters)}




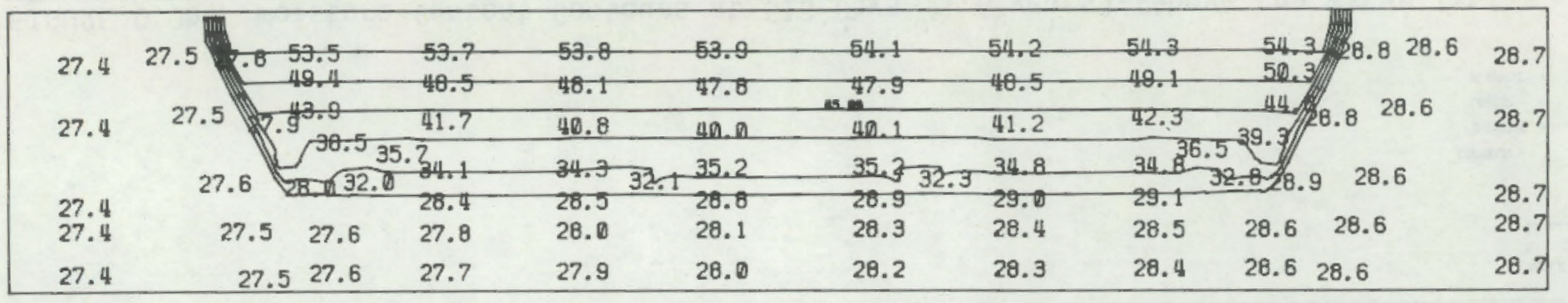

FIGURE D.4a. Hydraulic Potential Contours at 1498 Days (4.1 years)--Above the Water Table, Case 3 with Clay 8 ottom and Stub-Sidewall Liners with Drains (values in meters)

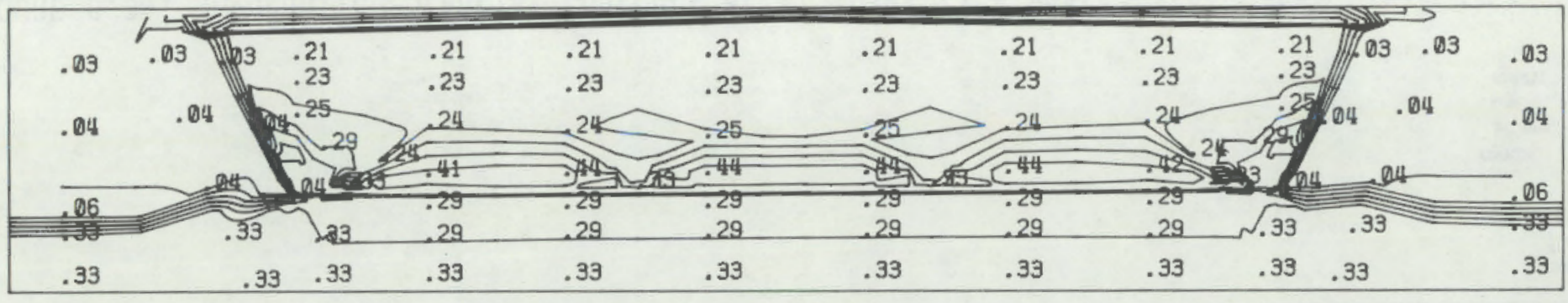




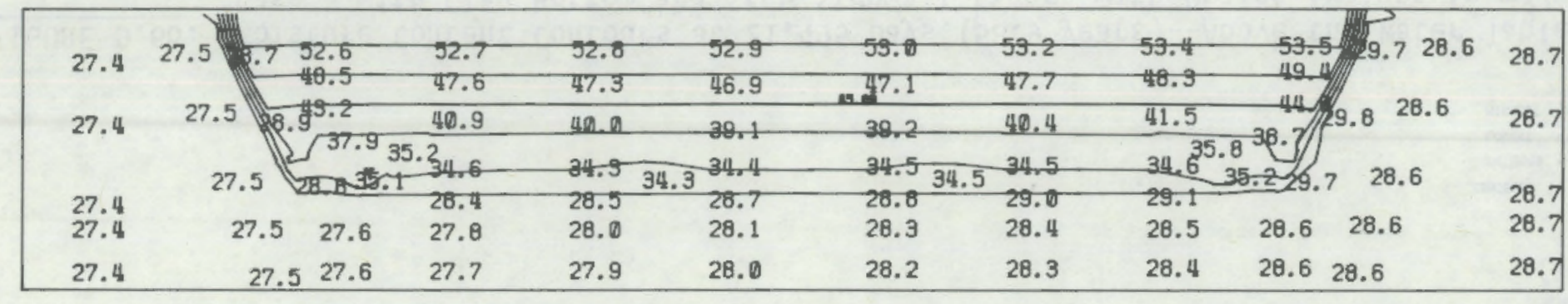

comon

InTENan - 5.6

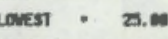

Mienst - m.m

FIGURE D.5a. Hydraulic Potential Contours at 6765 Days (18.5 years)--Above the Water Table, Case 3 with Clay Bottorn and Stub-Sidewall Liners with Drains (values in meters)

in

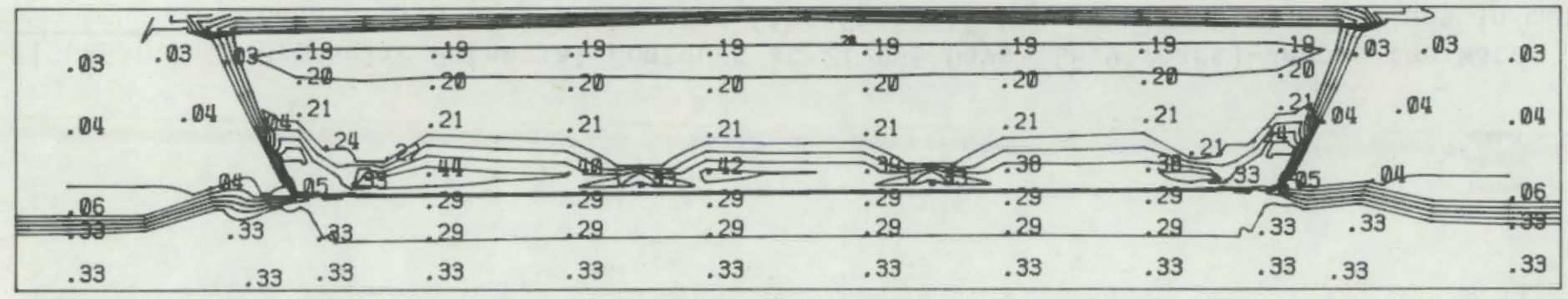

one uckass

arroun

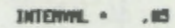

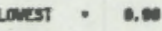

MJaEsT - .

FIGURE D.5b. Moisture Content Contours at 6765 Days (18.5 years)--Above the Water Table Case 3 with $\mathrm{Clay}$ Bottom and Stub-Sidewall Liners with Drains (values in $\mathrm{m}^{3} / \mathrm{m}^{3}$ ) 


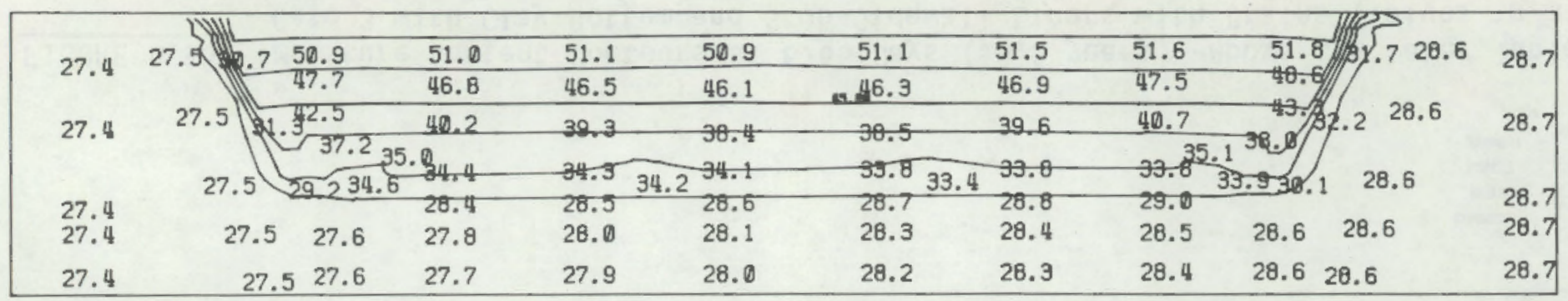

FIGURE D.6a. Hydraulic Potential Contours at 21,495 Days (58.9 years)--Above the Water Table, Case 3 with Clay Bottom and Stub-Sidewall Liners with Drains (values in meters)

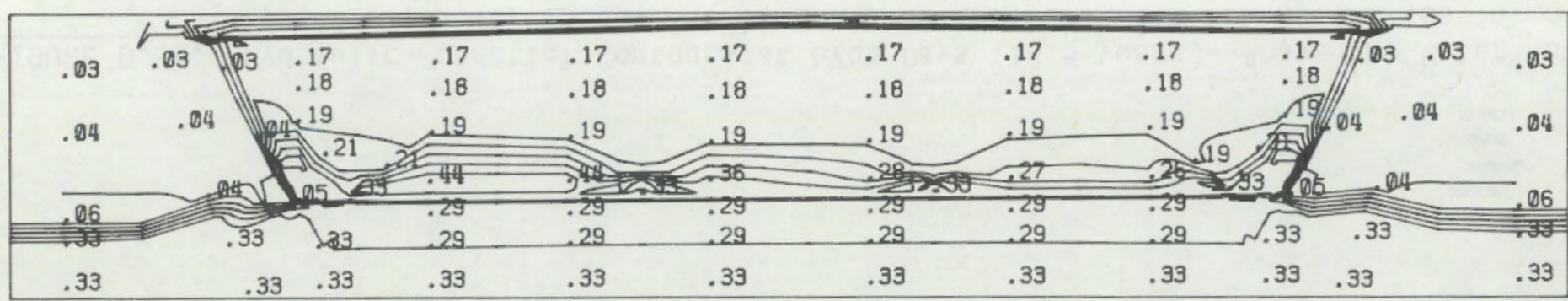


APPENDIX E

POTENTIAL AND MOISTURE CONTENT PLOTS: CASE 4 WITH HORIZONTAL WATER TABLE 


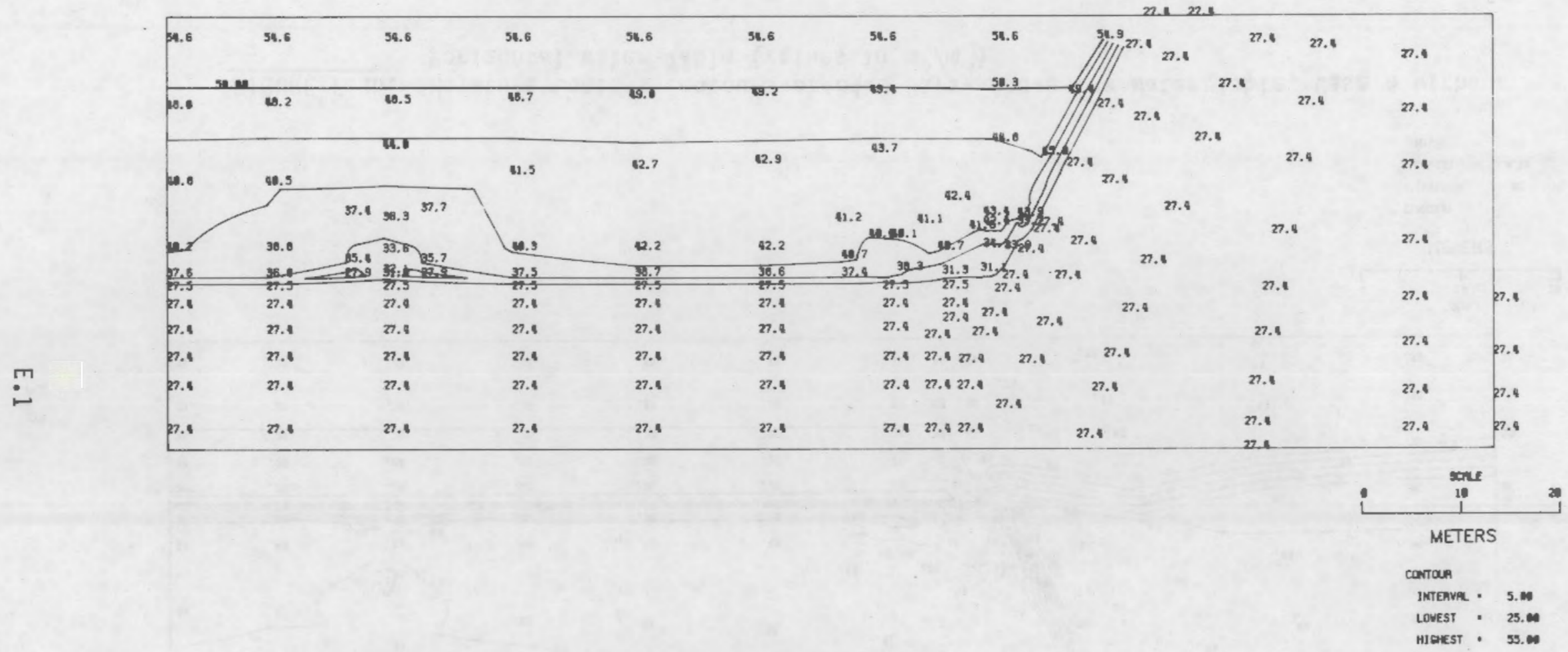

FIGURE E.1a. Hydraulic Potential Contours at 34.9 Days--Above the Water Table, Case 4 with Horizontal Water Table (values in meters) 


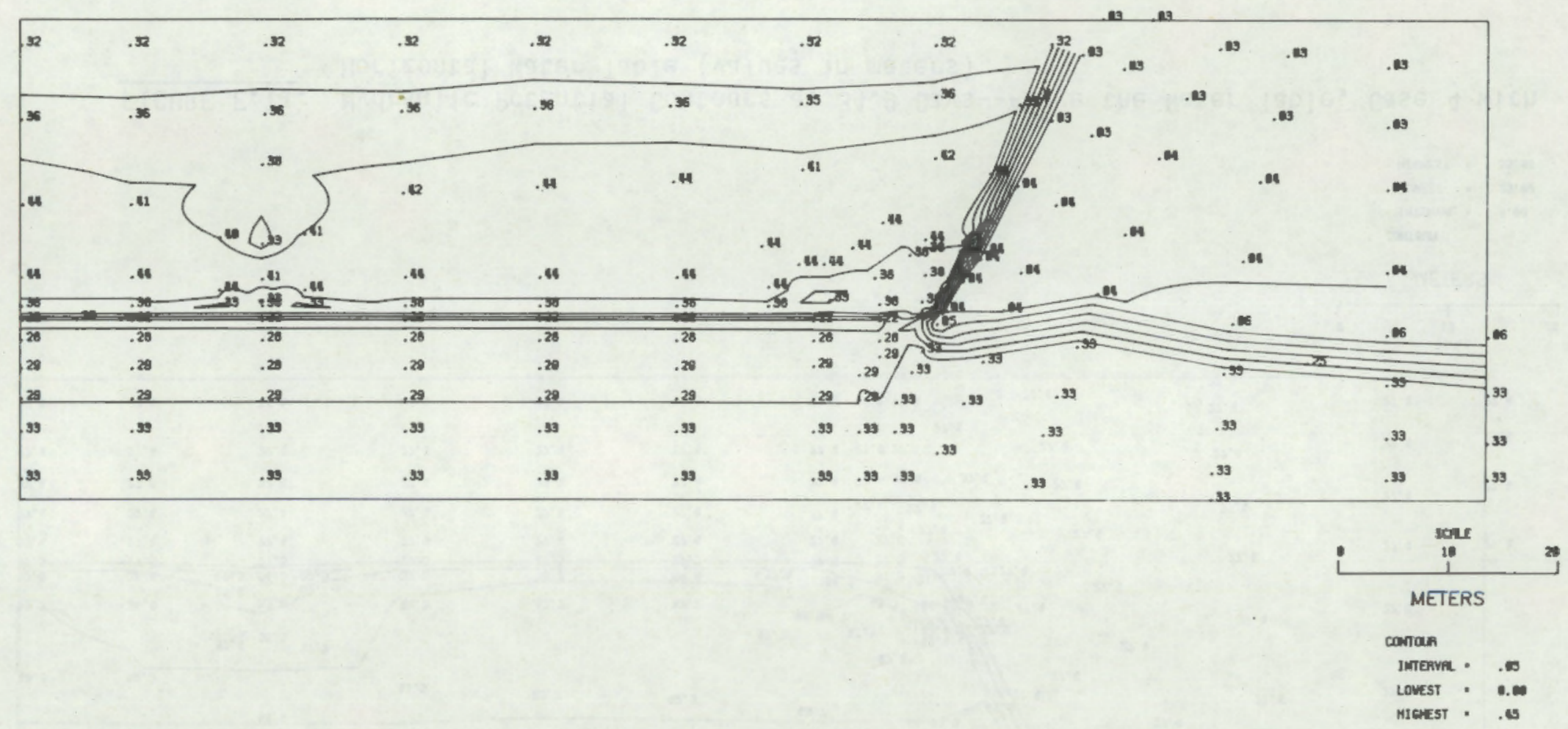

FIGURE E.ID: Moisture Content Contours at 34.9 Days-Above the WaternTabite, Case 4 with Horizontal Hater Table. (values in $\mathrm{m}^{3} / \mathrm{m}^{3}$ ) 


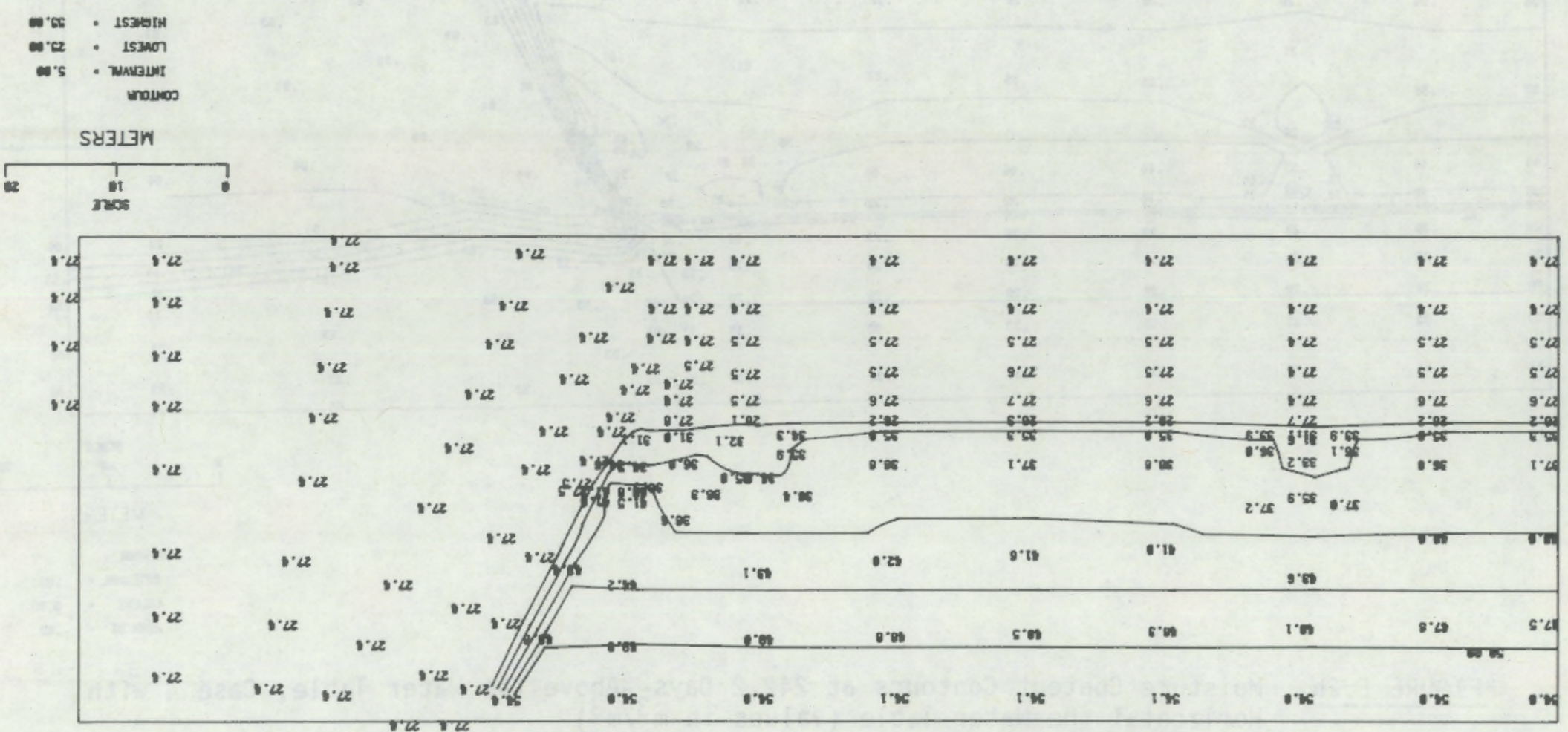




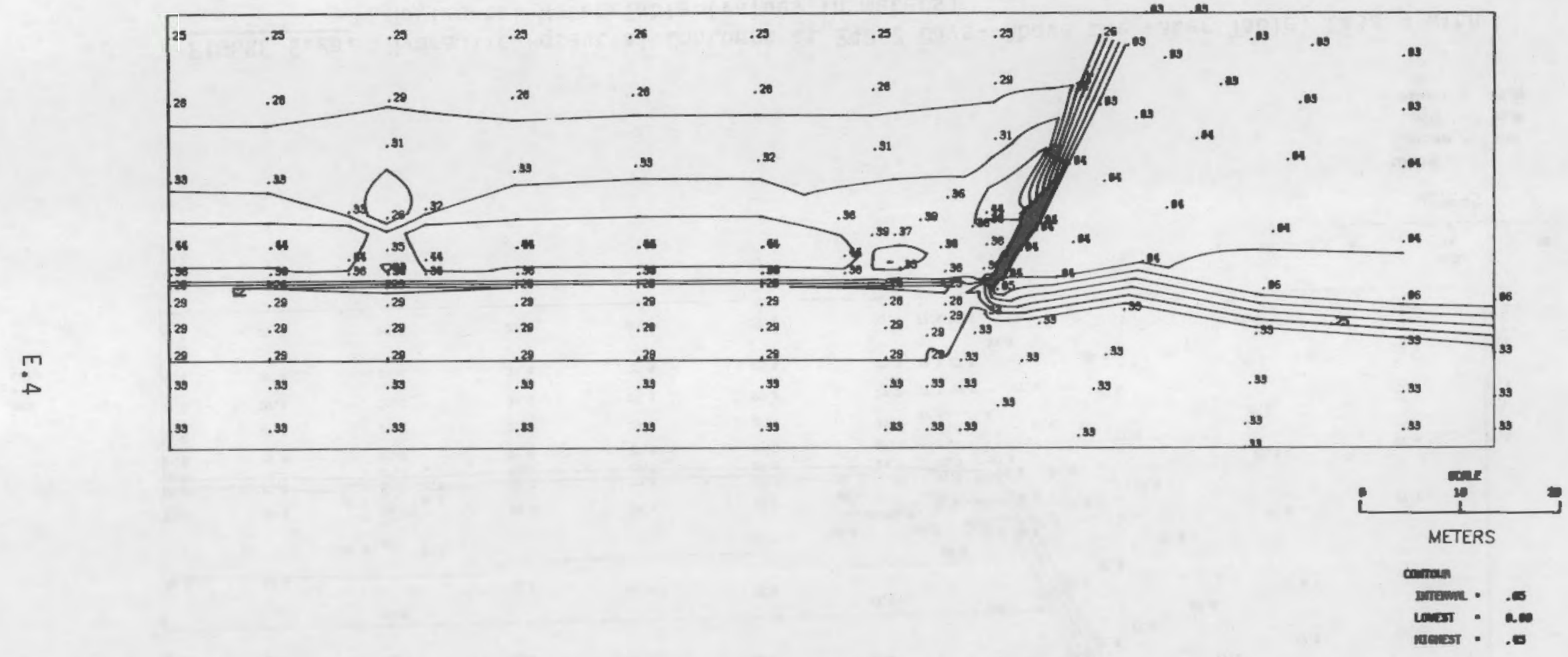

FIGURE E.2b. Moisture Content Contours at 242.2 Days-Above the water Table, Case 4 with Horizontal the Water Table (values in $\mathrm{m}^{3} / \mathrm{m}^{3}$ ) 


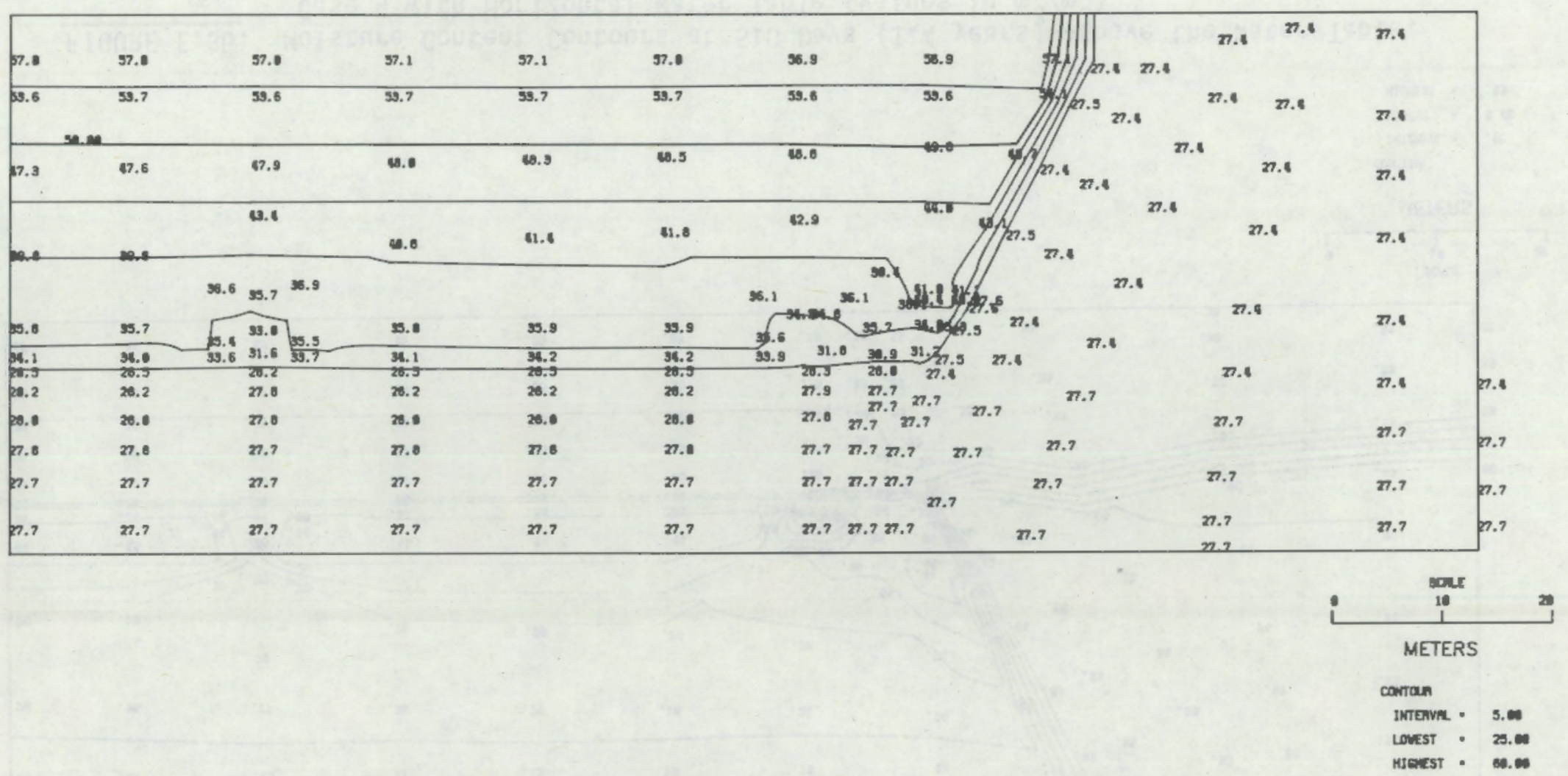

FIgURE E.3a. Hydraulic Potential Contours at 510 Days (1.4 years)--Above the Water Table, Case 4 with Horizontal Water Table (values in meters) 


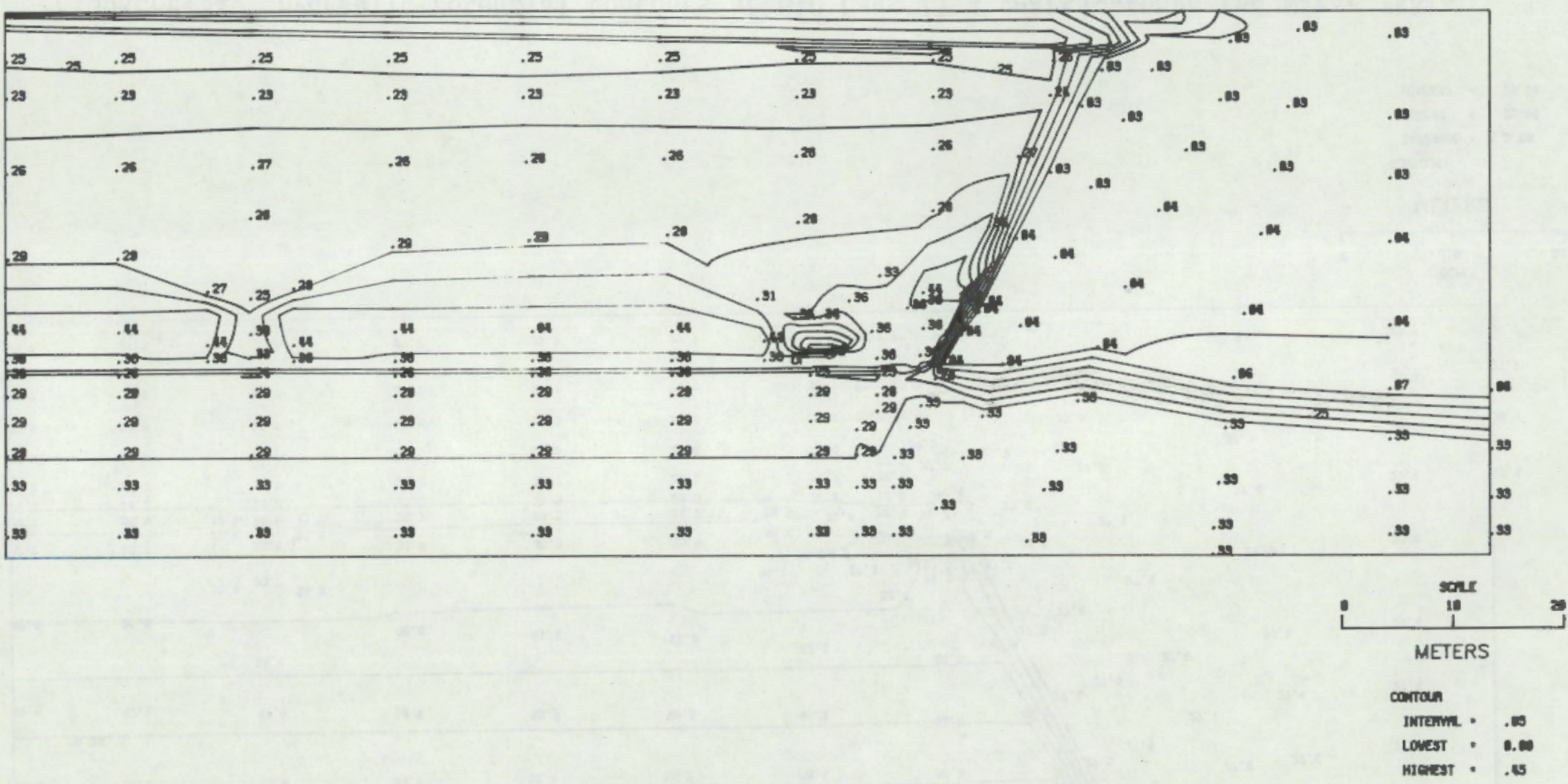

FIGURE E.3b. Moisture Content Contours at 510 Days ( 1.4 years)--Above the Water Table, Case 4 with Horizontal Water Table (values in $\mathrm{m}^{3} / \mathrm{m}^{3}$ ) 


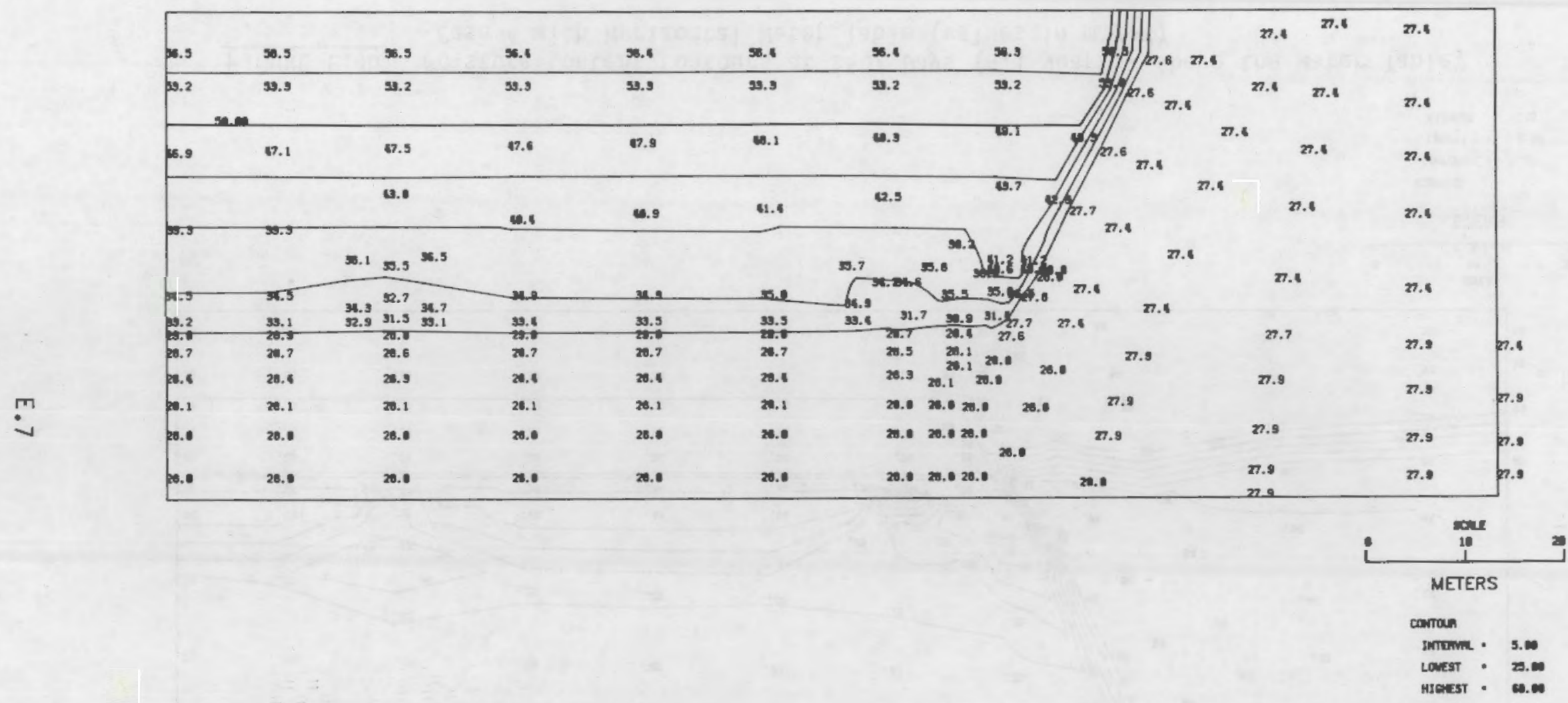

FIGURE E.4a. Hydraulic Potential Contours at 1507 Days (4.1 years)--Above the Water Table, Case 4 with Horizontal Water Table (values in meters) 


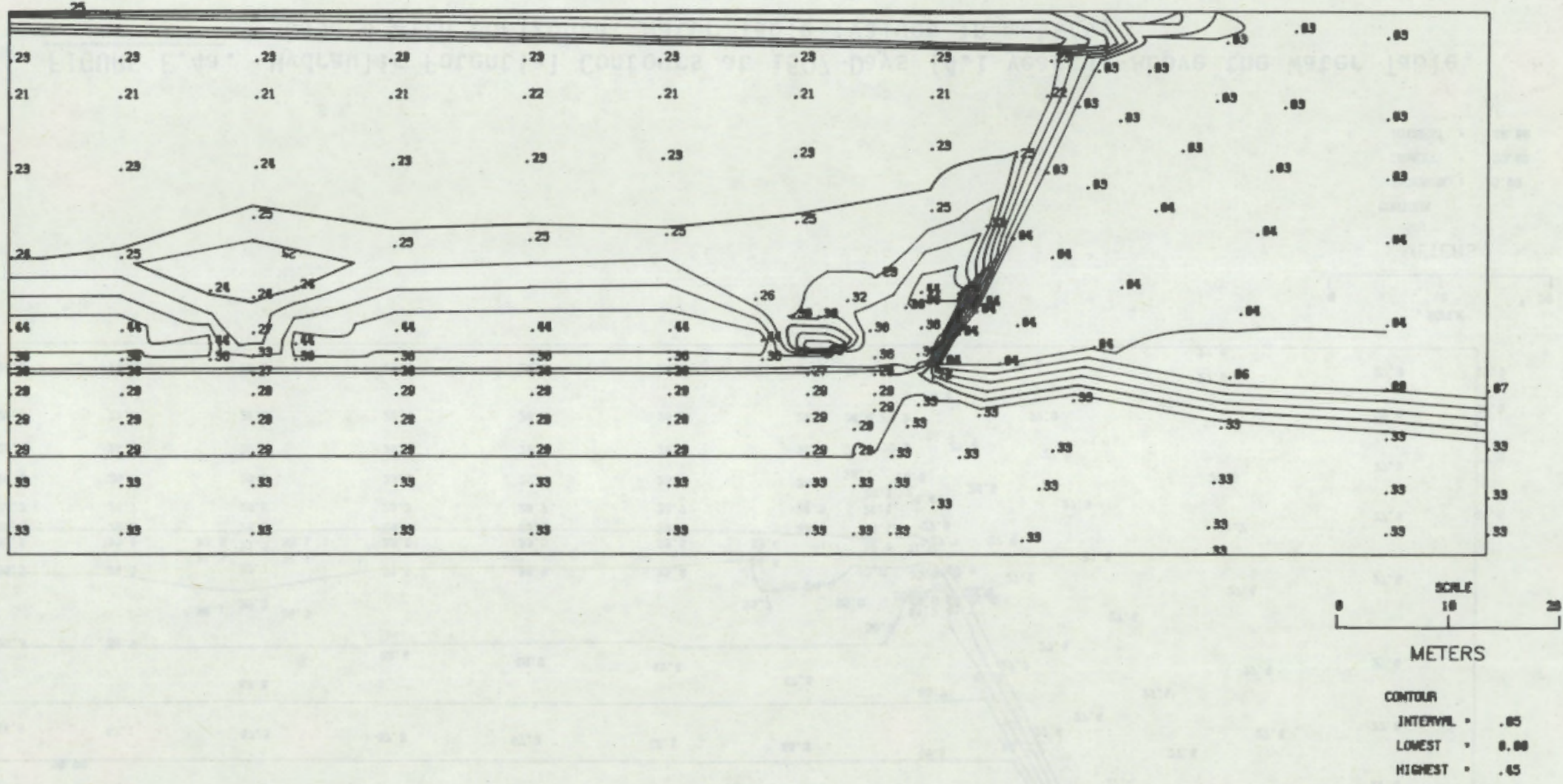

FIGURE E.4b. Moisture Content Contours at 1507 Days (4.1 yearş)--Above the Water Table, Case 4 with Horizontal Water Table (values in $\mathrm{m}^{3} / \mathrm{m}^{3}$ ) 


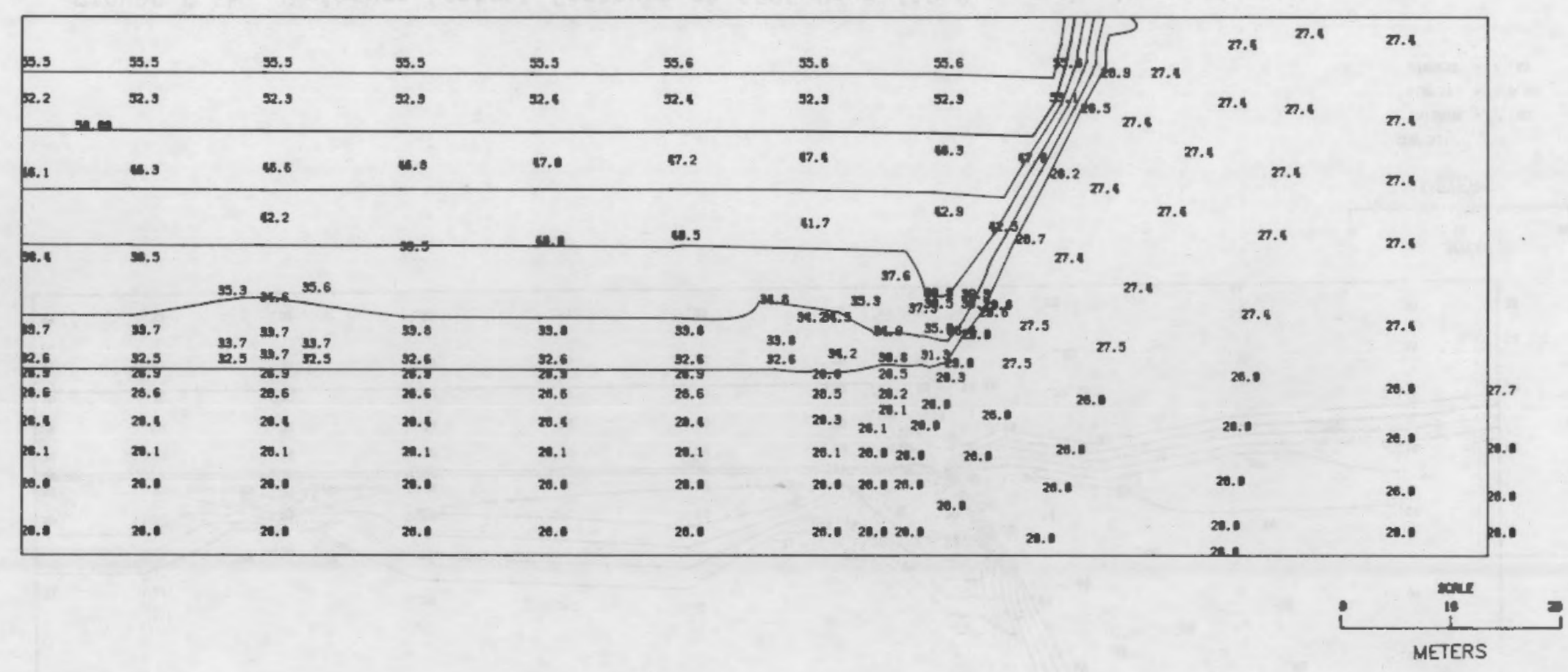

compen

ImItamk - S.6

Lavest - 25.

Mrenest - so.m

FIGURE E.5a. Hydraulic Potential Contours at 6696 Days (18.3 years)--Above the Water Table, Case 4 with Horizontal Water Table (values in meters) 


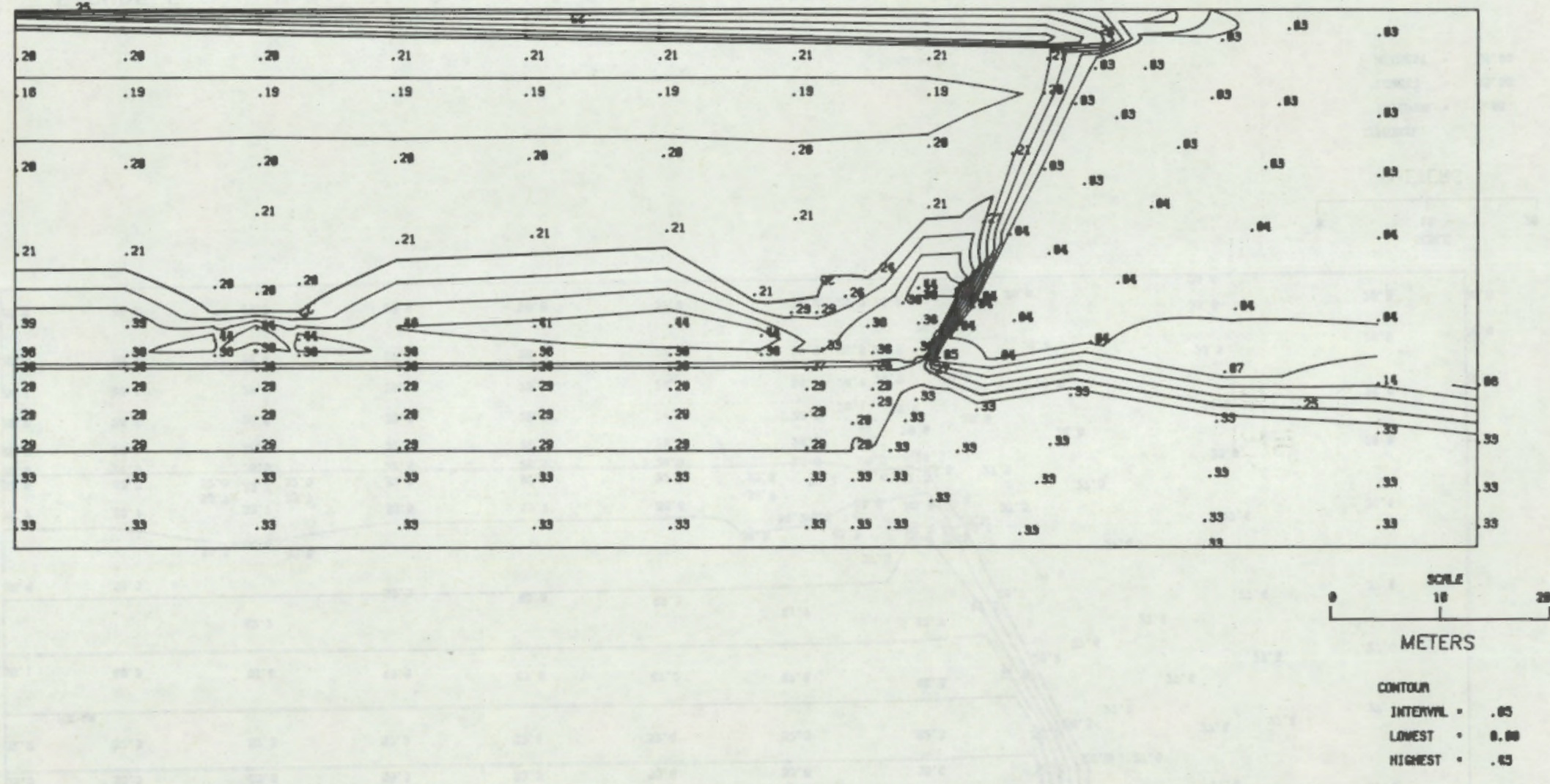

FIGURE E.5b. Moisture Content Contours at 6696 Days (18.3 years)--Above the Water Table, Case 4 with Horizontal Water Table (values in $\mathrm{m}^{3} / \mathrm{m}^{3}$ ) 
APPENDIX $F$

POTENTIAL AND MOISTURE CONTENT PLOTS: CASE 5--BELOW THE WATER TABLE REFERENCE CASE 


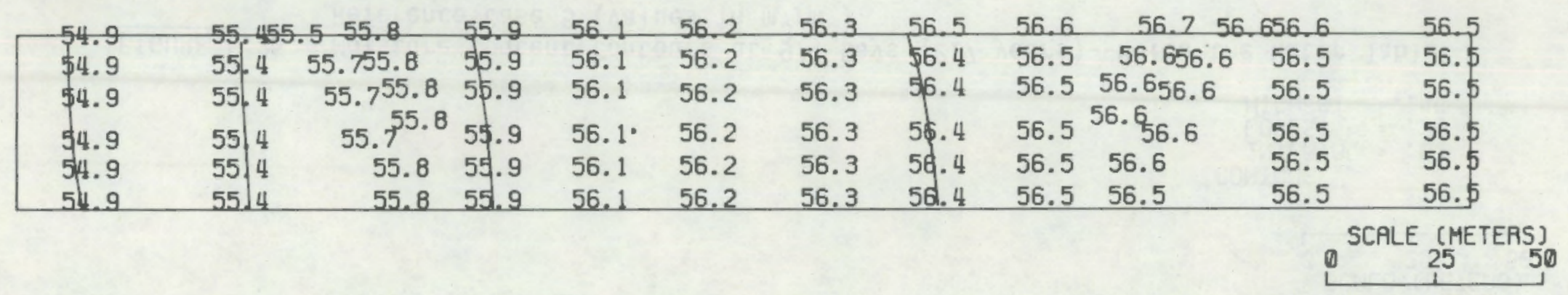

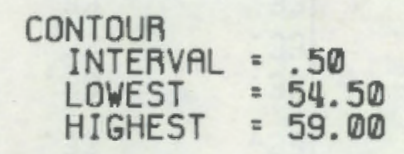

FIGURE F.1a. Hydraulic Potential Contours at 276 Days--Below the Water Table Reference Case 5 (values in meters)

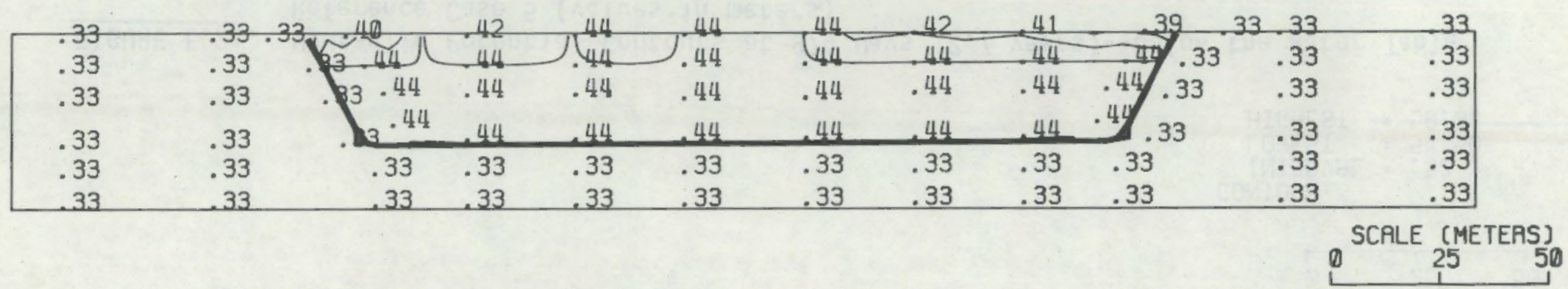
CONTOUR
INTERVAL $=.02$
LOWEST $=.28$
HIGHEST $=.46$

FIGURE F.1b. Moisture Content Contours at 276 Days--Below the Water Table

Reference Case 5 (values in $\mathrm{m}^{3} / \mathrm{m}^{3}$ ) 


\begin{tabular}{|c|c|c|c|c|c|c|c|c|c|c|c|}
\hline 54.9 & 55.35 & .555 .7 & 55.9 & 56. 1 & 56.2 & 56.3 & 56.4 & 56.4 & \multicolumn{2}{|c|}{$56.456,456,4$} & 56.5 \\
\hline 54.9 & $55 . \$$ & 55.655 .7 & 55. 9 & 56.1 & 56.2 & 56.3 & 56.3 & 56.4 & 56.456 .4 & 56.4 & 56.5 \\
\hline 54.9 & 55. 3 & $55.6^{55.8}$ & 55.9 & 56.0 & 56.2 & 56.3 & 56.3 & 56.4 & 56.456 .4 & 56.4 & $56 . \$$ \\
\hline 54.9 & 55.3 & $55.7^{55.8}$ & 55.9 & 56.0 & 56.2 & 56.3 & 56.3 & 56.4 & $56 . \frac{4}{56.4}$ & 56.4 & 56.5 \\
\hline 54.9 & 55.3 & 55.7 & 55.9 & 56.0 & 56.2 & 56.3 & 56.3 & 56.4 & 56.4 & 56.4 & 56.5 \\
\hline 54.9 & 55.3 & 55.7 & 55.9 & 56.0 & 56.2 & 56.3 & 56.3 & 56.4 & 56.4 & 56.14 & 56.5 \\
\hline
\end{tabular}

CONTOUR

INTERVAL $=.50$

LOWEST $=54.50$

FIGURE F.2a. Hydraulic Potential Contours at 974 Days (2.7 years)--Below the Water Table Reference Case 5 (values in meters)

\begin{tabular}{|c|c|c|c|c|c|c|c|c|c|c|}
\hline .33 & .33 & 38 & .40 & 42 & 44 & $.4 \pi$ & .39 & $32 \quad .36$ & .33 & .33 \\
\hline .33 & .33 & .44 & .44 & .44 & .44 & -44 & .44 & $44=43$ & .33 & .33 \\
\hline .33 & .33 & .44 & .44 & .44 & .44 & .44 & .44 & $.44 \quad .44 / .33$ & .33 & .33 \\
\hline .33 & .33 & $3^{.4}$ & 44 & .44 & .44 & 44 & .44 & .44 & .33 & .33 \\
\hline .33 & .33 & .33 & .33 & .33 & .33 & .33 & .33 & .33 & .33 & .33 \\
\hline .33 & .33 & .33 & .33 & .33 & .33 & .33 & .33 & .33 & .33 & .33 \\
\hline
\end{tabular}

$$
\begin{aligned}
\text { CONTOUR } & \\
\text { INTERVAL } & =.02 \\
\text { LOWEST } & =.28 \\
\text { HIGHEST } & =.46
\end{aligned}
$$

FIGURE F.2b. Moisture Content Contours at 974 Days (2.7 years)--Below the Water Table Reference Case 5 (values in $\mathrm{m}^{3} / \mathrm{m}^{3}$ ) 


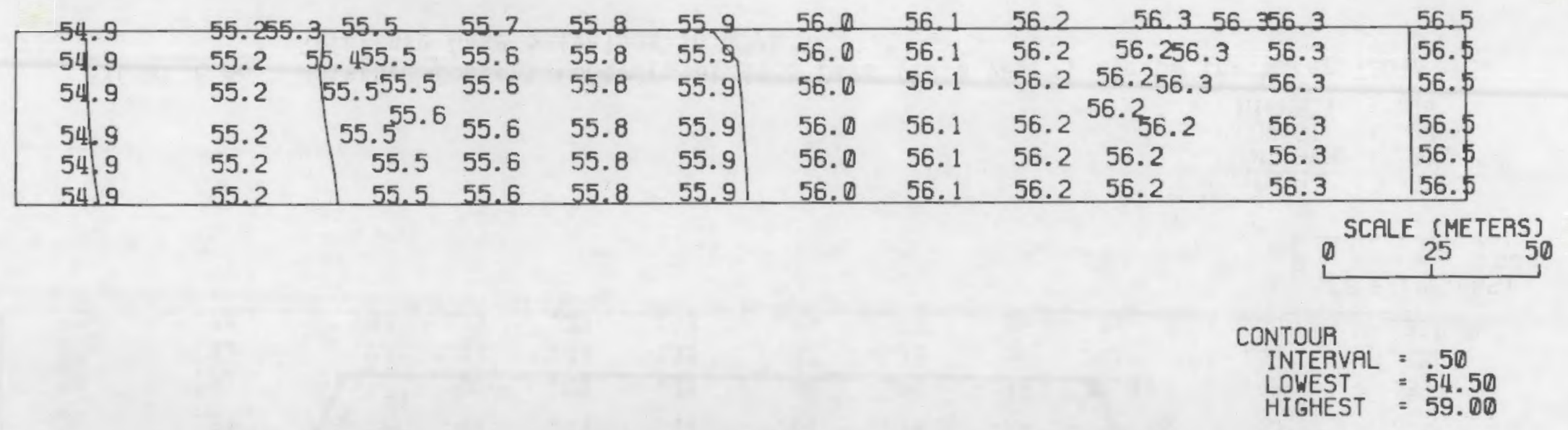

FIGURE F.3a. Hydraulic Potential Contours at 2092 Days (5.7 years)--Below the Water Table Reference Case 5 (values in meters)

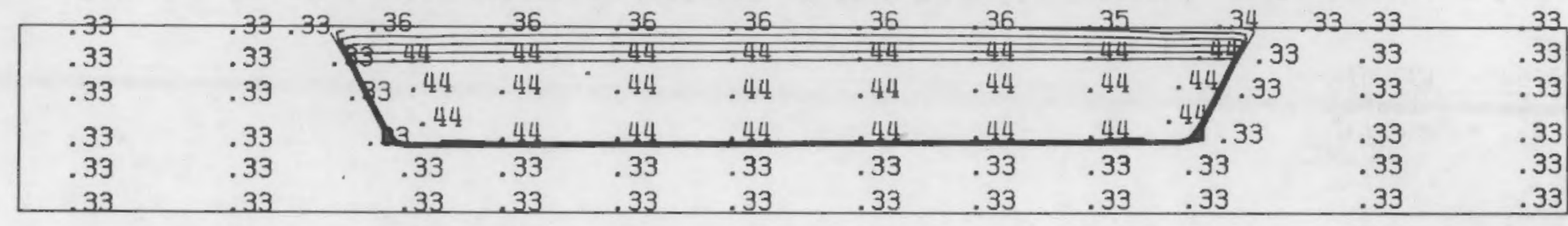

FIGURE F.3b. Moisture Content Contours at 2092 Days (5.7 years)--Below the Water Table Reference Case 5 (values in $\mathrm{m}^{3} / \mathrm{m}^{3}$ ) 


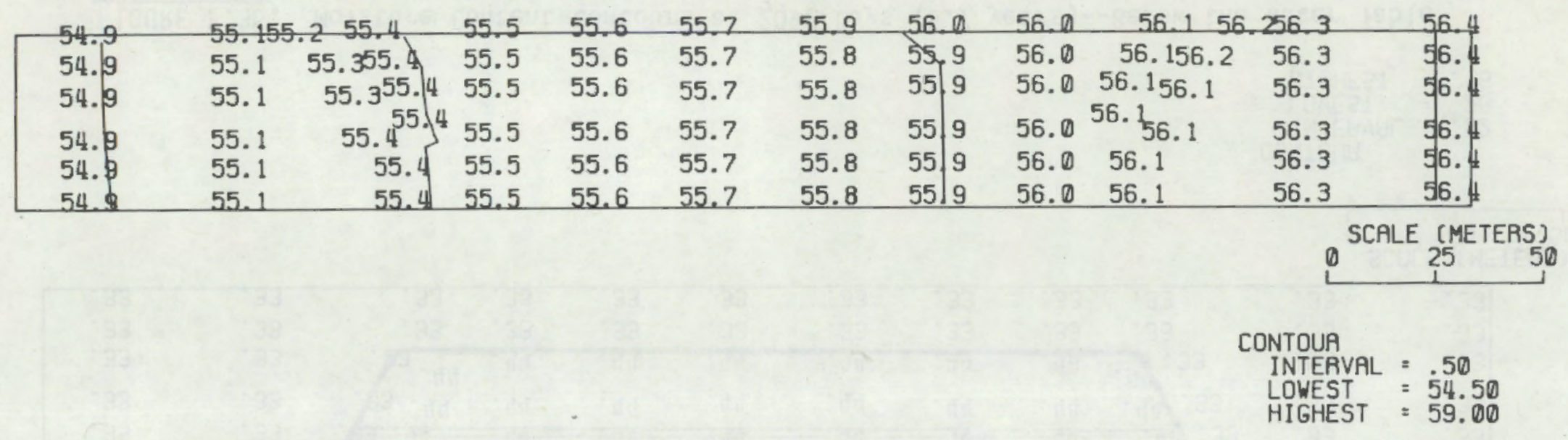

FIGURE F.4a. Hydraulic Potential Contours at 4488 Days (12.3 years)--Below the Water Table Reference Case 5 (values in meters)

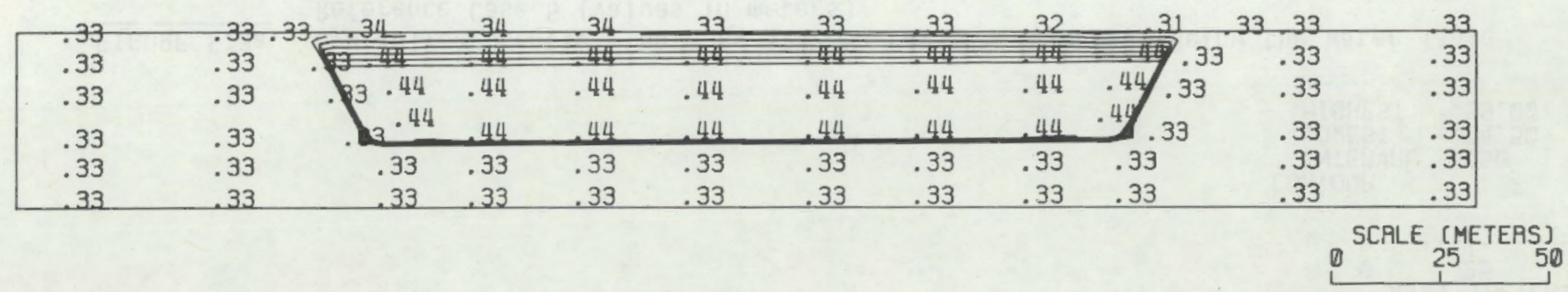

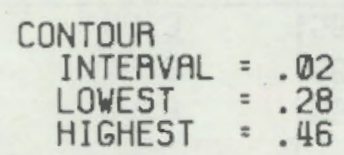

FIGURE F.4b. Moisture Content Contours at 4488 Days (12.3 years)--Below the Water Table Reference Case 5 (values in $\mathrm{m}^{3} / \mathrm{m}^{3}$ ) 


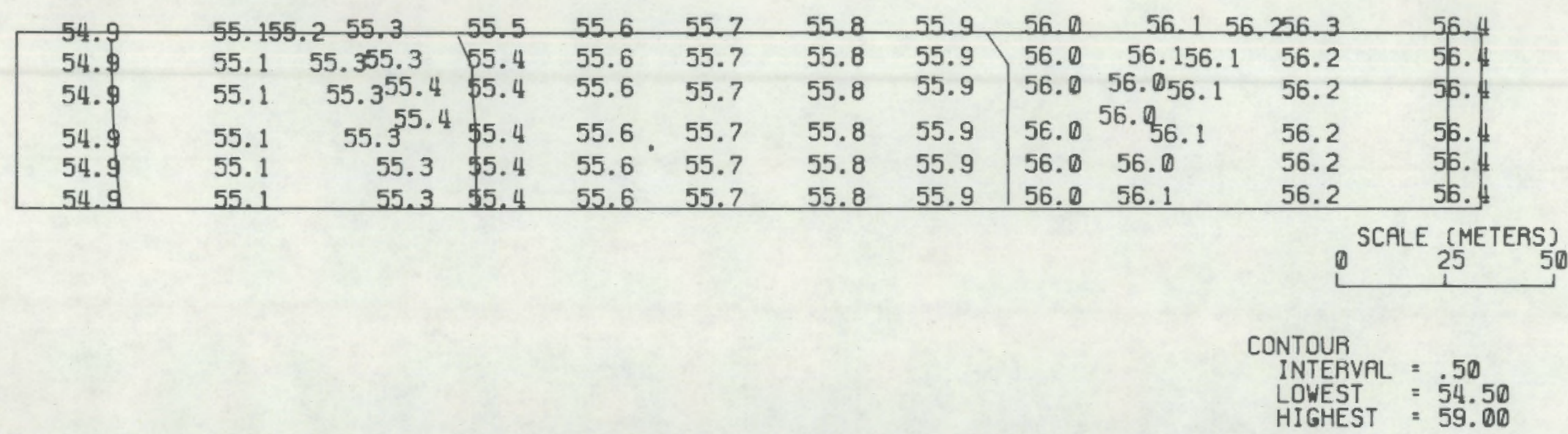

FIGURE F.5a. Hydraulic Potential Contours at 6486 Days ( 17.8 years)--Below the Water Table Reference Case 5 (values in meters)

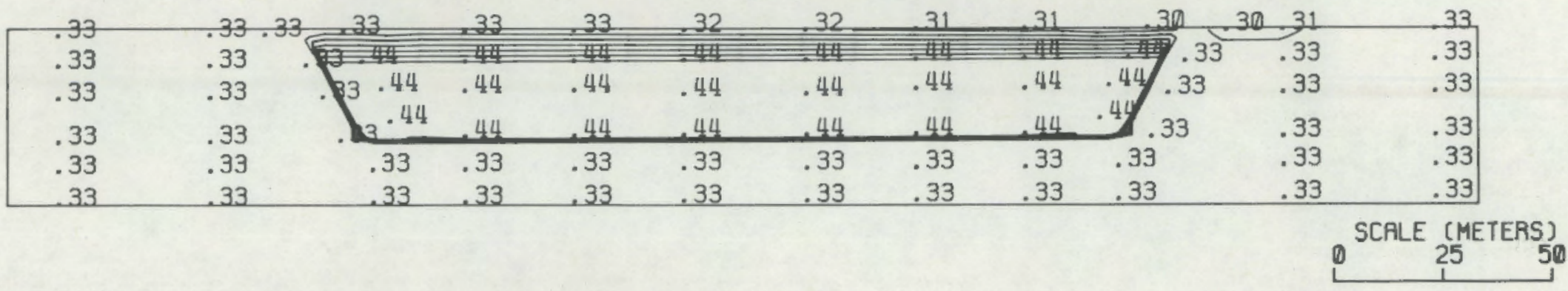

$$
\begin{aligned}
\text { CONTOUR } & \\
\text { INTERVAL } & =.02 \\
\text { LOWEST } & =.26 \\
\text { HIGHEST } & =.46
\end{aligned}
$$

FIGURE F.5b. Moisture Content Contours at 6486 Days (17.8 years)--Below the Water Table Reference Case 5 (values in $\mathrm{m}^{3} / \mathrm{m}^{3}$ ) 

APPENDIX G

POTENTIAL AND MOISTURE CONTENT PLOTS: CASE 6-WITH CLAY BOTTOM LINER 


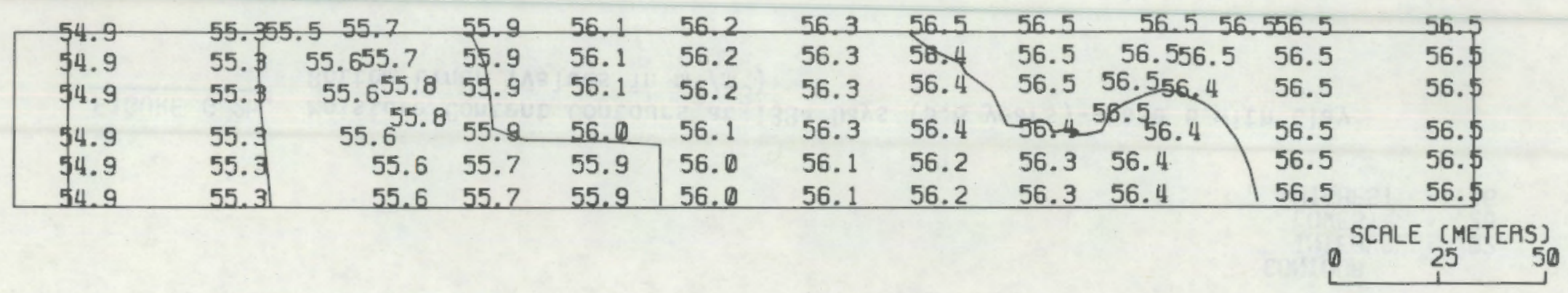

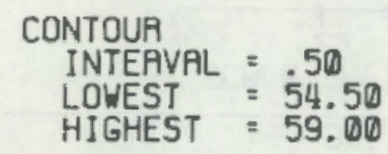

FIGURE G.1a. Hydraulic Potential Contours at 713 Days (1.95 years)--Case 6 with Clay Bottom Liner (values in meters)

$\because$

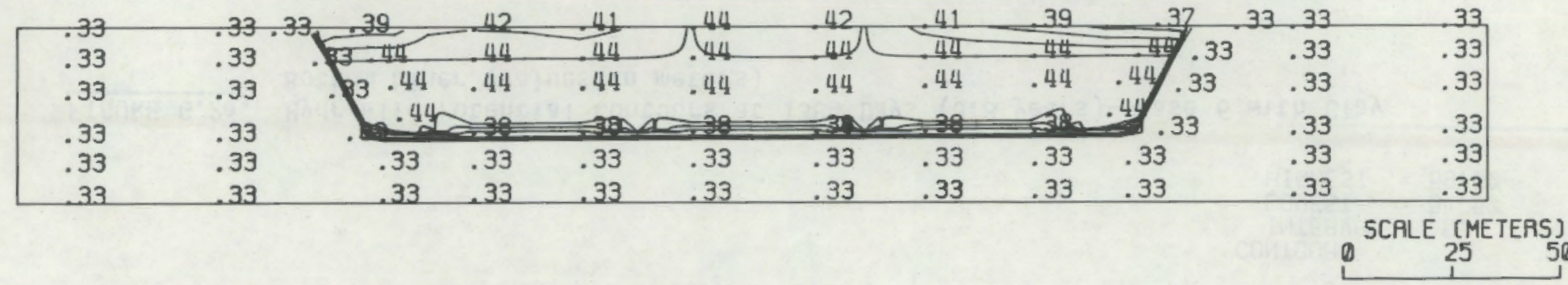

CONTOUA
INTERVAL $=.02$
LOWEST $=.28$
HIGHEST $=.46$

FIGURE G.1b. Moisture Content Contours at 713 Days (1.95 years)--Case 6 with Clay Bottom Liner (values in $\mathrm{m}^{3} / \mathrm{m}^{3}$ ) 


\begin{tabular}{|c|c|c|c|c|c|c|c|c|c|c|c|}
\hline-54.9 & 55.35 & .455 .6 & 55.9 & 56.0 & 56.2 & 56.3 & 56.3 & 56.3 & 56.45 & 456.4 & 56.5 \\
\hline 54.9 & 55.3 & 55.555 .7 & 55.9 & 56.0 & 56.2 & 56.3 & 56.3 & 56.3 & 56.456 .4 & 56.4 & 56. \\
\hline 54.9 & 55.3 & $55.6^{55.7}$ & 55.9 & 56.0 & 56.2 & 56.3 & 56.3 & 56.3 & 56.356 .4 & 56.4 & 56. \\
\hline 54.9 & 55.3 & $55.6^{55.7}$ & $55.8^{2}$ & 56.0 & 56.1 & 56.2 & 56.3 & 56.3 & $56 . \frac{3}{56.3}$ & 56.4 & 56. \\
\hline 54.9 & 55.3 & 55.6 & 55.7 & 55.8 & 55.9 & 56.0 & 56.1 & 56.2 & 56.3 & 56.4 & 56. \\
\hline 54.9 & 55.3 & 55.6 & 55.7 & 55.8 & $55 . \theta$ & 56.0 & 56.1 & 56.2 & 56.3 & 56.4 & 56. \\
\hline
\end{tabular}
CONTOUR
INTEAVAL $=.50$
LOWEST $=54.50$
HIGHEST $=59.00$

FIGURE G.2a. Hydraulic Potential Contours at 1384 Days (3.8 years)--Case 6 with Clay Bottom Liner (values in meters)

$\stackrel{n}{\text { in }}$

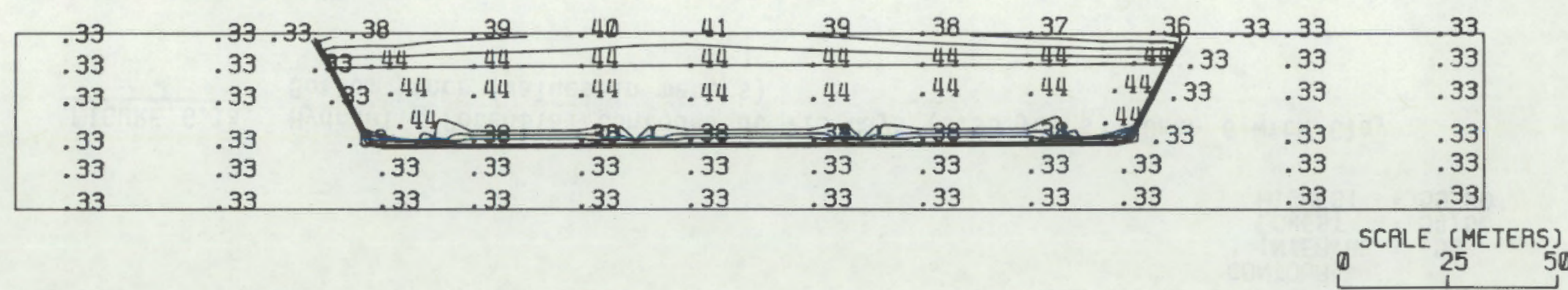

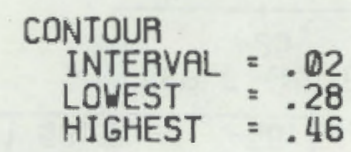

FIGURE G.2b. Moisture Content Contours at 1384 Days (3.8 years)--Case 6 with Clay Bottom Liner (values in $\mathrm{m}^{3} / \mathrm{m}^{3}$ ) 


\begin{tabular}{|cccccccccccc|c|}
54.9 & 55.255 .3 & 55.5 & 55.6 & 55.8 & 55.9 & 56.0 & 56.1 & 56.2 & 56.3 & 56.356 .3 & 56.5 \\
54.9 & 55.2 & 55.455 .5 & 55.6 & 55.8 & 55.9 & 56.0 & 56.1 & 56.2 & 56.256 .3 & 56.3 & 56.5 \\
54.9 & 55.2 & 55.455 .5 & 55.6 & 55.8 & 55.9 & 56.0 & 56.1 & 56.2 & 56.256 .2 & 56.3 & 56.5 \\
54.9 & 55.2 & 55.4 & 55.6 & 55.7 & 55.8 & 56.0 & 56.1 & 56.1 & 56.2 & 56.2 & 56.3 & 56.5 \\
54.9 & 55.2 & 55.4 & 55.5 & 55.7 & 55.8 & 55.9 & 56.0 & 56.1 & 56.2 & 56.3 & 56.5 \\
54.9 & 55.2 & 55.4 & 55.5 & 55.7 & 55.8 & 55.9 & 56.0 & 56.1 & 56.2 & 56.3 & 56.5
\end{tabular}

SCALE [METERS)

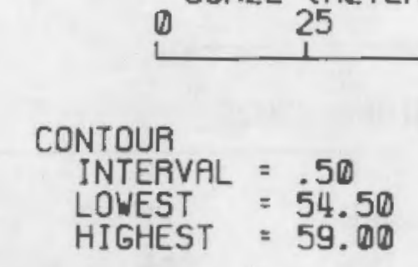

FIGURE G.3a. Hydraulic Potential Contours at 2548 Days (7 years)--Case 6 with Clay Bottom Liner (values in meters)

o

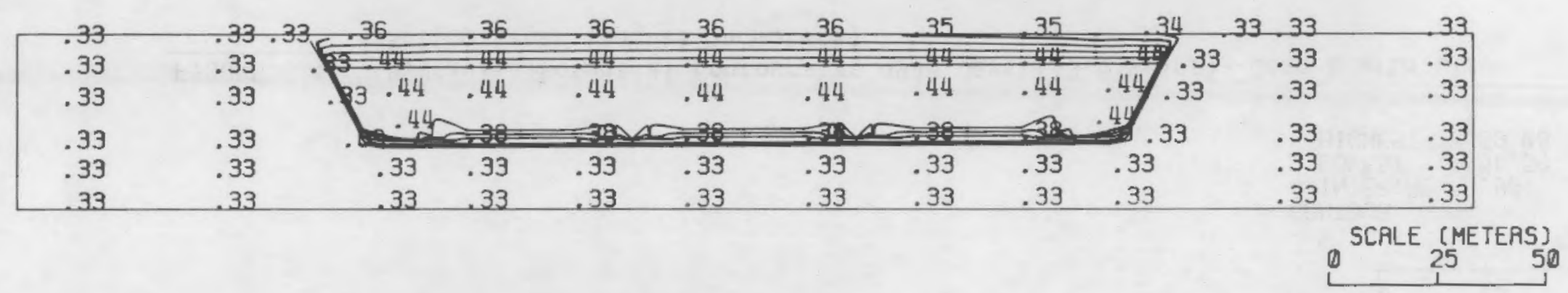

$$
\begin{aligned}
& \text { CONTOUR } \\
& \text { INTERVAL }=.02 \\
& \text { LOWEST }=.28 \\
& \text { HIGHEST }=.46
\end{aligned}
$$

FIGURE G.3b. Moisture Content Contours at 2548 Days (7 years)--Case 6 with Clay Bottom Liner (values in $\mathrm{m}^{3} / \mathrm{m}^{3}$ ) 


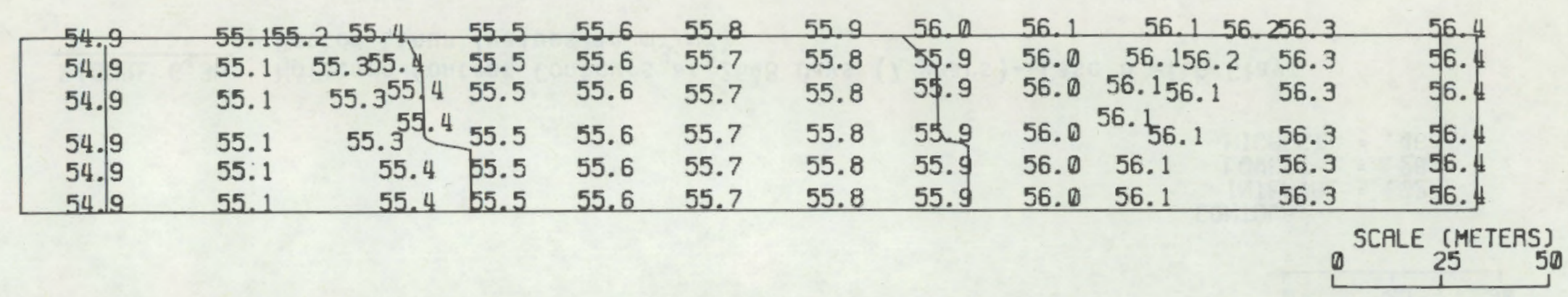

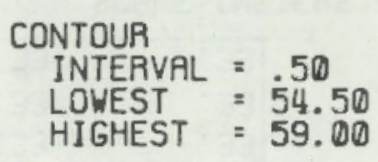

FIGURE G.4a. Hydraulic Potential Contours at 4948 Days (13.6 years)--Case 6 with Clay Bottom Liner (values in meters)

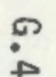

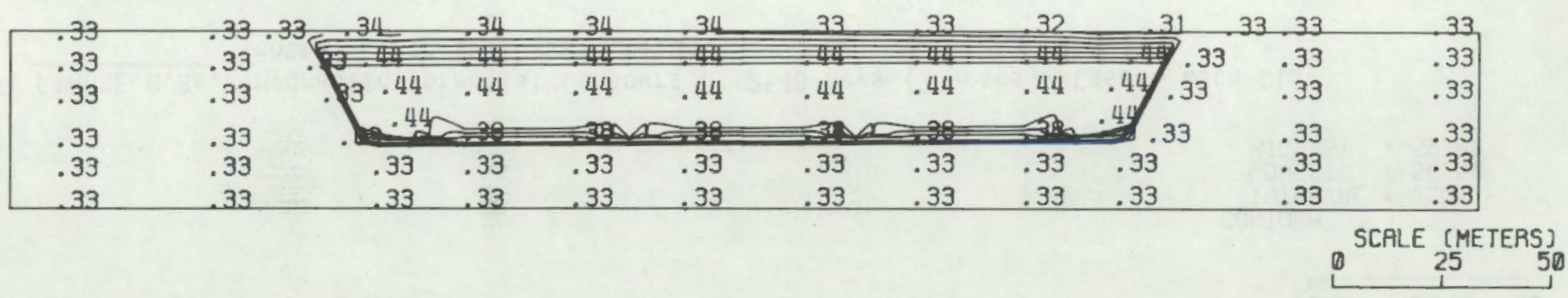

$$
\begin{aligned}
& \text { CONTOUR } \\
& \text { INTERVAL }=.02 \\
& \text { LOWEST }=. .28 \\
& \text { HIGHEST }=.46
\end{aligned}
$$

FIGURE G.4b. Moisture Content Contours at 4948 Days (13.6 years)--Case 6 with Clay Bottom Liner (values in $\mathrm{m}^{3} / \mathrm{m}^{3}$ ) 


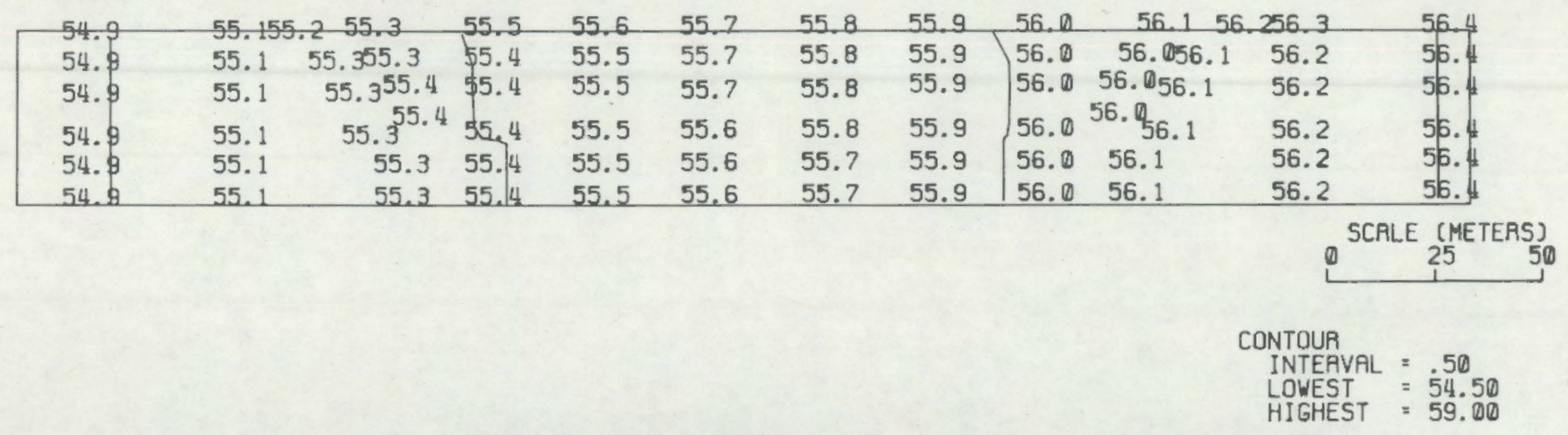

FIGURE G.5a. Hydraulic Potential Contours at 7913 Days (21.7 years)--Case 6 with Clay Bottom Liner (values in meters)

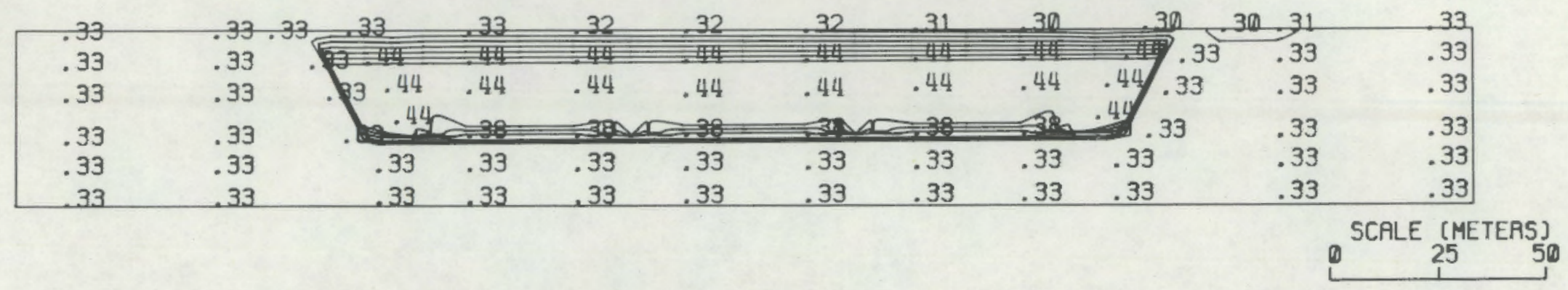

CONTOUR

INTERVAL $=.02$

$\begin{array}{ll}\text { LINEST } & =.28 \\ & =.46\end{array}$

FIGURE G.5b. Maisture Content Contours at 7913 Days (21.7 years)--Case 6 with Clay Bottom Liner (values in $\mathrm{m}^{3} / \mathrm{m}^{3}$ ) 

APPENDIX H

POTENTIAL AND MOISTURE CONTENT PLOTS: CASE 7-WITH CLAY BOTTOM AND STUB-SIDEWALL. LINERS WITH DRAINS 


\begin{tabular}{|c|c|c|c|c|c|c|c|c|c|c|c|}
\hline 48.8 & 48.9 & $49.040 .1 \frac{55.0}{50.8}$ & $\frac{55.1}{19.8}$ & $\frac{55.2}{49.4}$ & $\frac{55.4}{48.0}$ & $\frac{55.5}{49.1}$ & $\frac{55.6}{10.8}$ & $\frac{55.7}{50.4}$ & $\frac{55.8}{51.7} 50.150 .1$ & 50.2 & 50.3 \\
\hline 48.7 & 48.7 & 48.748 .87 .2 & -43.5 & 42.2 & 41.3 & 41.4 & & & & 50.2 & 50.3 \\
\hline 48.7 & 48.7 & 48.748 .6 & $\frac{42.6}{49.0}$ & $\begin{array}{l}4 \hat{.15} \\
49.1\end{array}$ & $\frac{40.4}{49.3}$ & $\frac{40.2}{49.5}$ & $2 \frac{41.8}{49.6}$ & & 50.150 .1 & 50.2 & 50.3 \\
\hline 48.7 & 48.7 & $48.7 \quad 48.8$ & 48.9 & 49.1 & 49.3 & 49.5 & 49.7 & 499 & 50.050 .1 & 50.2 & 50.3 \\
\hline 48.7 & 48.7 & 48.748 .8 & 48.9 & 49.1 & 49.3 & 49.5 & 49.7 & 49.9 & 50.050 .1 & 50.2 & 50.3 \\
\hline
\end{tabular}

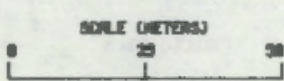

camroun

12rewm. - 5.

Lotest :

HJatest -

FIGURE H.1a. Hydraulic Potential Contours at 32.7 Days--Case 7 with Clay Bottom and Stub-Sidewall Liners with Drains (values in meters)

and Stub-Sidewall Liners with Drains (values in meters)

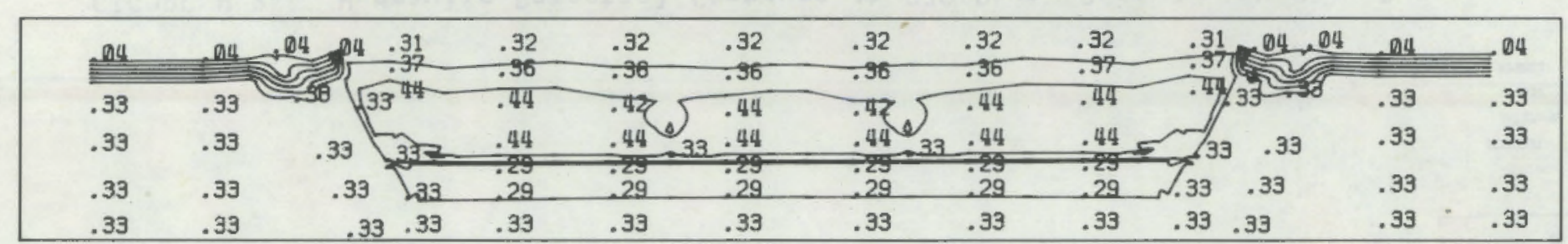

.33 .39

.39

.33

.33

.33

.33

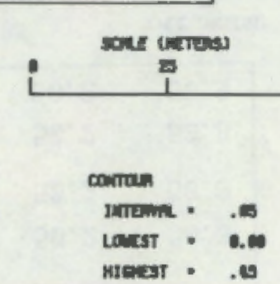

FIGURE H.1b. Moisture Content Contours at 32.7 Days--Case 7 with Clay Bottom and Stub-Sidewall Liners with Draias (values in $\mathrm{m}^{3}{ }^{3}$ ). 


\begin{tabular}{|c|c|c|c|c|c|c|c|c|c|c|c|c|}
\hline 48.8 & 48.9 & 49.049 .154 .3 & $\begin{array}{r}54.5 \\
49.2\end{array}$ & $\begin{array}{r}54.6 \\
-48.8\end{array}$ & $\begin{array}{r}54.7 \\
-48.5\end{array}$ & $\begin{array}{r}54.9 \\
.9 .6\end{array}$ & $\frac{55.0}{40.3}$ & $\begin{array}{l}55.1 \\
49.9 \\
\end{array}$ & $\frac{55 .}{51.2} 50.150 .1$ & 50.2 & 50.3 & \\
\hline 48.7 & 48.6 & $48.648 .46,6$ & 42.0 & 41.7 & 40.8 & 40.9 & 42.1 & 43.2 & 47290.050 .0 & 50.2 & 50.3 & \\
\hline 48.7 & 48.6 & 48.6485 & 37.5 & 37.4 & 43.5 & 37.6 & 38.0 & 38.2 & 50.0 & 50.2 & 50.3 & \\
\hline 48.7 & 48.6 & $\begin{array}{lll}48.6 & 48.7\end{array}$ & $\begin{array}{l}47.6 \\
48.7\end{array}$ & $\begin{array}{l}47.7 \\
48.8\end{array}$ & $\begin{array}{l}47.9 \\
46.9\end{array}$ & $\begin{array}{l}48.1 \\
49.1\end{array}$ & $\begin{array}{l}48.3 \\
49.3\end{array}$ & $\begin{array}{l}40.5 \\
49.6\end{array}$ & 9.950 .0 & 50.2 & 50.3 & \\
\hline 48.7 & 48.6 & 48.648 .7 & 48.8 & 49.0 & 49.2 & 49.4 & 49.6 & 49.8 & 49.950 .0 & 50.2 & 50.3 & \\
\hline & & & & & & & & & & $i$ & ache uकाए & ase \\
\hline & & & & & & & & & & & 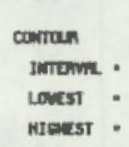 & $\underset{0.00}{5.0 .10}$ \\
\hline
\end{tabular}

FIGURE H.2a. Hydraulic Potential Contours at 270 Days--Case 7 with Clay Bottom and Stub-Sidewall Liners with Drains (values in meters)

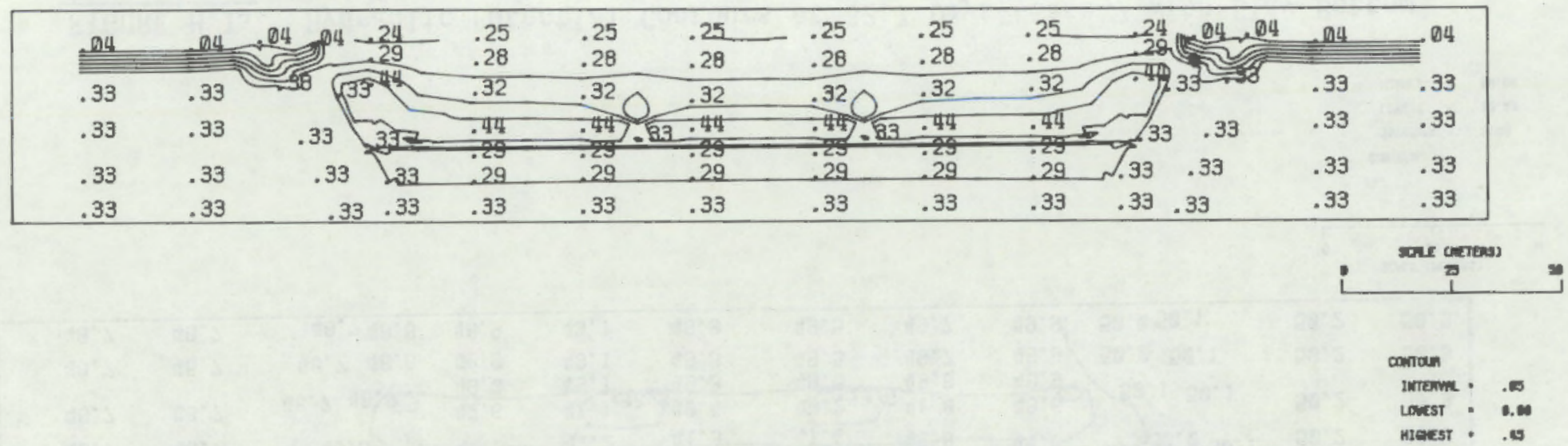

FIGURE H.2b. Moisture Content Contours at 270 Days--Case 7 with Clay Bottom and Stub-Sidewall Liners with Drains (values in $\mathrm{m}^{3} / \mathrm{m}^{3}$ ) 


\begin{tabular}{|c|c|c|c|c|c|c|c|c|c|c|c|c|}
\hline & 48.8 & 48.9 & 49.049 .255 .7 & $\begin{array}{r}53.9 \\
-48.8\end{array}$ & $\begin{array}{r}54.1 \\
-48.5\end{array}$ & $\begin{array}{r}54.1 \\
-40.2\end{array}$ & $\begin{array}{r}54.3 \\
-40.3\end{array}$ & $\begin{array}{l}54.4 \\
-48.8\end{array}$ & $\begin{array}{r}54.5 \\
49.5\end{array}$ & $\begin{array}{l}54.550 .250 .1 \\
50.9\end{array}$ & 50.2 & 50.3 \\
\hline - & 48.7 & 48.6 & 48.648 .45 .4 & 42.2 & 41.3 & 40.4 & 40.6 & 41.7 & & 47.99 .950 .0 & 50.1 & 50.3 \\
\hline & 48.7 & 48.6 & $48.640 \sqrt{\mathrm{s}}$ & 36.3 & 36.3 & $3^{36.3}$ & 36.13 & 36.9 & 37.2 & 80.050 .0 & 50.1 & 50.3 \\
\hline & 48.7 & 48.6 & $\begin{array}{ll}48.6 & 48.7\end{array}$ & 48.6 & 48.7 & $\begin{array}{l}47.7 \\
48.9\end{array}$ & $\begin{array}{l}47.9 \\
49.1\end{array}$ & 48.1 & 49.6 & 49.950 .0 & 50.1 & 50.3 \\
\hline & 48.7 & 48.6 & 48.648 .7 & 48.8 & 49.0 & 49.2 & 49.4 & 49.6 & 49.8 & $49 \mathrm{C}_{90.0}$ & 50.1 & 50.3 \\
\hline
\end{tabular}

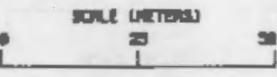

carran

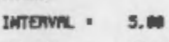

Lonest : s.m

FIGURE H.3a. Hydraulic Potential Contours at 747 Days (2 years)--Case 7 with Clay Bottom and Stub-Sidewall Liners with Drains (values in meters)

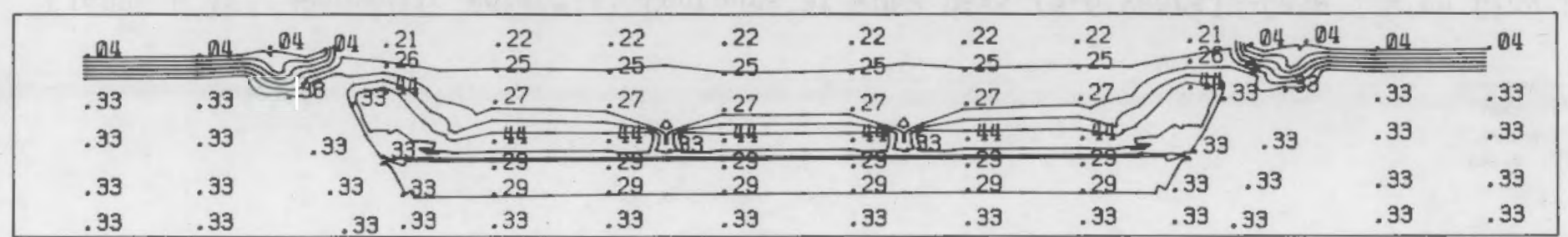

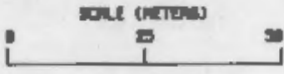

comon

IMtems - .es

Lovest : in

FIGURE H.3b. Moisture Content Contours at 747 Days (2 years)--Çase 7 with Clay Bottom and Stub-Sidewall Liners with Drains (values in $\mathrm{m}^{3} / \mathrm{m}^{3}$ ) 


\begin{tabular}{|c|c|c|c|c|c|c|c|c|c|c|c|}
\hline 48.8 & 48.9 & 49.049 .352 .9 & $\begin{array}{r}53.2 \\
40.3\end{array}$ & $\begin{array}{l}53.3 \\
47.9\end{array}$ & $\begin{array}{r}53.4 \\
-47.8\end{array}$ & $\begin{array}{r}53.5 \\
-47.7\end{array}$ & $\begin{array}{r}53.7 \\
-40.3\end{array}$ & $\begin{array}{l}53.8 \\
-48.8\end{array}$ & $\begin{array}{l}53.8 \\
50.4\end{array} 50.350 .1$ & 50.2 & 50.3 \\
\hline 48.7 & 48.6 & 48.648 .46 & 41.8 & 40.9 & 40.9 & 40.1 & 41.3 & 42.4 & 47.8 .950 .0 & 50.1 & 50.3 \\
\hline 48.7 & 48.6 & $48.642 \sqrt{3}$ & 36.1 & 36.932 & $2^{35.7}$ & $35.2=$ & $5^{36.5}$ & & 50.0 & 50.1 & 50.3 \\
\hline 48.7 & 48.6 & $48.6 \quad 48.7$ & $\begin{array}{l}47.4 \\
48.6\end{array}$ & 48.7 & $\begin{array}{l}47.0 \\
48.9\end{array}$ & $\begin{array}{l}47.0 \\
49.1\end{array}$ & $\begin{array}{l}48.1 \\
49.3\end{array}$ & 49.6 & 4 4. 950.0 & 50.1 & 50.3 \\
\hline 48.7 & 48.6 & 48.648 .7 & 48.8 & 49.0 & 49.2 & 49.4 & 49.6 & 49.8 & $4 9 \longdiv { 9 5 0 . 0 }$ & 50.1 & 50.3 \\
\hline & & & & & & & & & & i & mar une \\
\hline & & & & & $x$ & & & & & & $\begin{array}{l}\text { carroun } \\
\text { Intenme : } \\
\text { Lovest : } \\
\text { meacst : }\end{array}$ \\
\hline
\end{tabular}

FIGURE H.4a. Hydraulic Potential Contours at 2062 Days (5.6 years)--Case 7 with Clay Bottom and Stub-Sidewall Liners with Drains (values in meters)

$\stackrel{1}{+}$

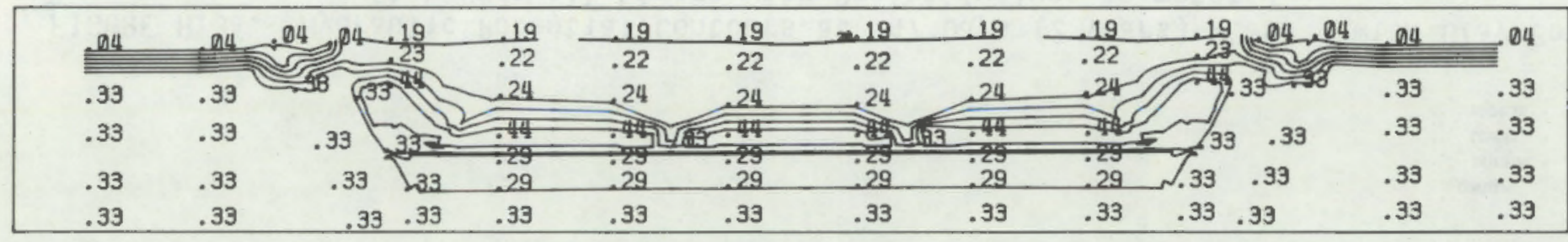

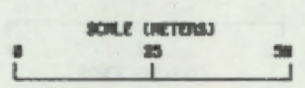

cosroun

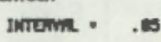

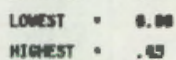

FIGURE H.4b. Moisture Content Contours at 2062 Days (5.6 years $-{ }^{-}$Case 7 with Clay Bottom and Stub-Sidewall Liners with Drains (values in $\mathrm{m}^{3}{ }^{3}$ ) 
No. of

Copies

U.S. Nuclear Regulatory Commission

Division of Technical Information and Document Control

7920 Norfolk Avenue

Bethesda, MD 20014

D. F. Harmon

Nuclear Regulatory Commission

Office of Nuclear Research

Mail Stop 1130-SS

Washington, DC 20555

3 P. R. Meyer

SRA 9405

Eagle River, AK 99577

T. J. Nicholson/G. F. Birchad/

D. Alexander

Office of Nuclear Research

Nuclear Regulatory Commission

Mail Stop 1130 SS

Washington, DC 20555

G. N. Gnugnoli

Office of Nuclear Research

Nuclear Regulatory Commission

Mail Stop 467-SS

Washington, DC 20555

Richard $B$. White

Ford, Bacon \& Davis - Utah

375 Chipeta Way

P.0. Box 8009

Salt Lake City, UT

2 T. N. Narasimhan

Lawrence Berkeley Laboratory

Earth Sciences; Bldg 90

Berkeley, CA 94720

P. M. Kearle

Bendix FEC

P.0. Box 1569

Grand Junction, CO 81502
No. of

Copies

Tom Shephard

Colorado State Univ.

Geotechnica Engr. Program

Civil Engr. Dept.

Fort Collins, Co 80523

Lyal Davis

Colorado State Univ. Geotechnica Engr. Program

Civil Engr. Dept.

Fort Collins, CO 80523

Ben Doty

Golden Associates

12345 W. Alameda Pkwy.

Lakewood, CO 80228

Kathryn Bush

GECR Inc.

P.0. Box 725

Rapid City, SD 57709

Walter Barber

Jacobs-Weston Team

5301 Central Ave, Suite 1700

Albuquerque, NM 87108

James Brinkman

Sergent Hauskins Beckwith

5301 Central Ave, Suite 1700

Albuquerque, NM 87108

Don Diego Gonzales

UMTRAP Program

Sandia National Laboratories

Albuquerque, NM 87185

Patrick Brannon

Sandia National Laboratories

Albuquerque, NM 87185 
No. of

Copies

ONSITE

50 Pacific Northwest Laboratory

M. G. Foley (2)

G. W. Gee (2)

C. T. Kincaid

B. K. Marshall

D. W. Mayer (2)

T. J. McKeon

R. W. Nelson (22)

C. A. Newbill

P. L. Oberlander (2)

A. E. Reisenauer (2)

S. G. Sneider (2)

Technical Information (5)

Publishing Coordination (BE)

Geosciences Research and

Engineering Department

Technical Library (5)

मे.S. GOVERMMENT PRINTING OFFICE: 1983-381-297:3005 


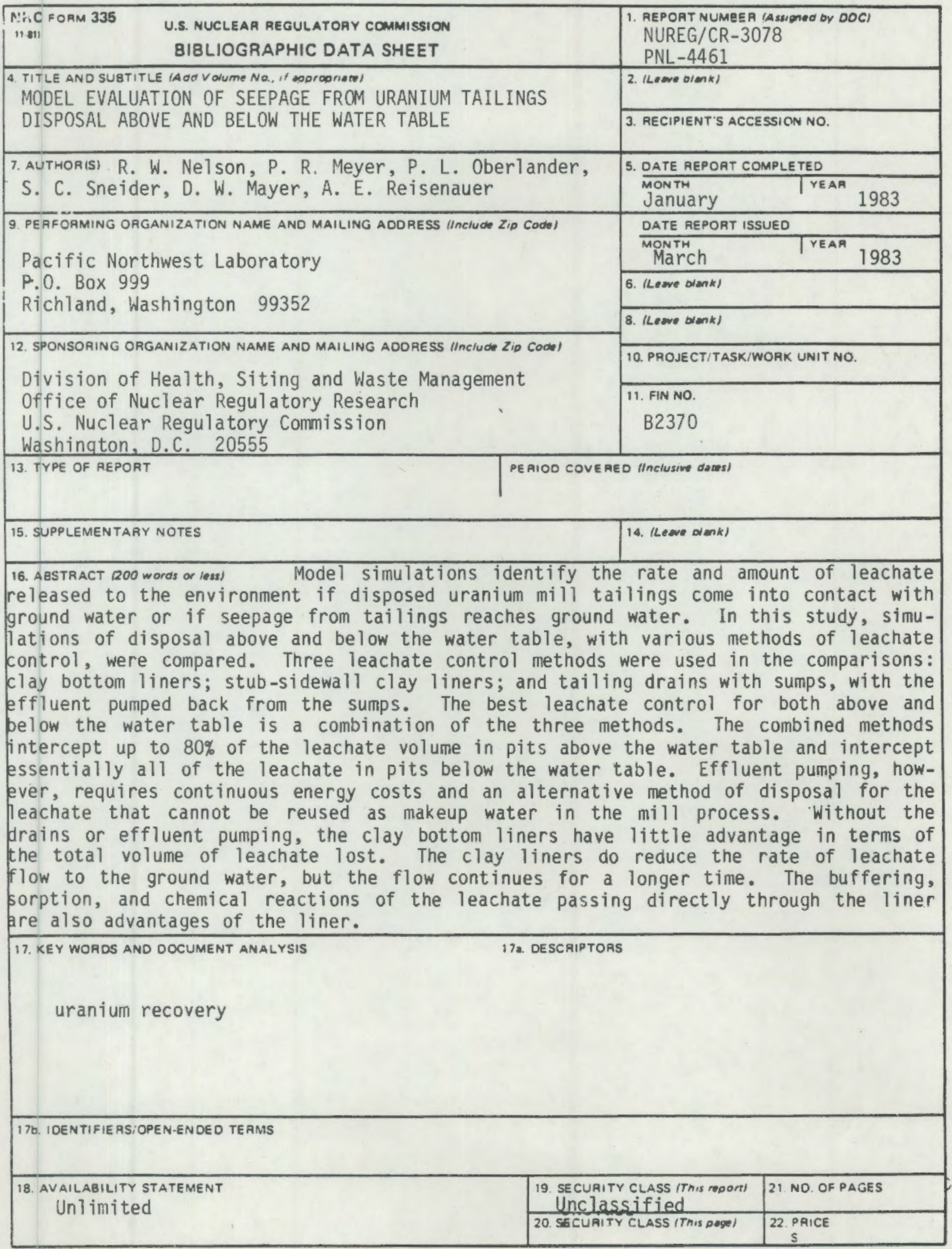


